\title{
MONETARY POLICY OPERATING PROCEDURES IN INDUSTRIAL COUNTRIES
}

by

Claudio E. V. Borio

March 1997

BANK FOR INTERNATIONAL SETTLEMENTS

Monetary and Economic Department

BASLE 
BIS Working Papers are written by members of the Monetary and Economic Department of the Bank for International Settlements, and from time to time by outside economists, and published by the Bank. The papers are on subjects of topical interest and are technical in character. The views expressed in them are those of their authors and not necessarily the views of the BIS.

(C) Bank for International Settlements 1997

CH-4002 Basle, Switzerland

Also available on the BIS World Wide Web site (http://www.bis.org).

All rights reserved. Brief excerpts may be reproduced or translated provided the source is stated. 


\title{
MONETARY POLICY OPERATING PROCEDURES IN INDUSTRIAL COUNTRIES *
}

by

\author{
Claudio E. V. Borio
}

March 1997

\begin{abstract}
In recent years monetary policy operating procedures have continued to evolve in the light of changes in the structure and workings of financial markets as well as in the broader economic and political environment. Since the mid-1980s, central banks have further strengthened the market-orientation of policy implementation, cut reserve requirements, widened the range of available instruments, increased the flexibility of liquidity management, sharpened the focus on interest rates as operating targets, improved the transparency of policy signals and shortened the maturity of interest rates serving as the fulcrum of policy. While these trends have resulted to some extent in a continuation of the process of convergence dating back to at least the 1970s, significant differences still exist across countries. This paper reviews current monetary policy implementation procedures within a common framework in order to highlight similarities and remaining differences across countries. It also provides some information about their evolution in recent years and suggests possible explanations for the main forces underlying the observed changes.
\end{abstract}

* This paper was prepared for the BIS Autumn Meeting of Central Bank Economists, 28th-29th October 1996. This and the other participants' papers are published in Bank for International Settlements "Implementation and tactics of monetary policy", Conference Papers Vol. 3, March 1997. 



\section{Contents}

Introduction

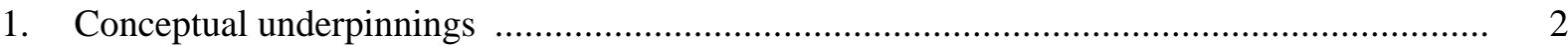

$1.1 \quad$ The demand for bank reserves ........................................................................... 2

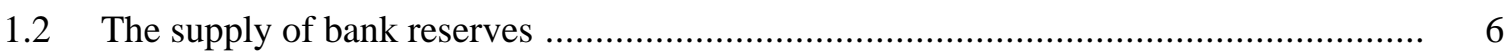

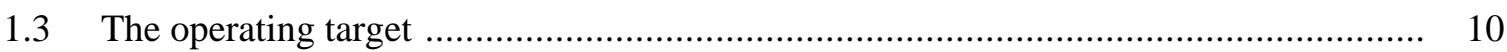

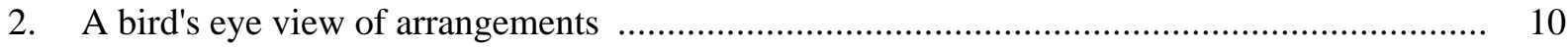

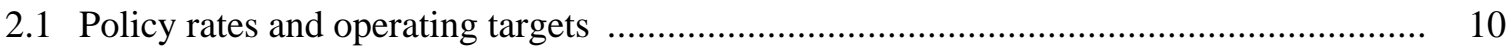

2.2 Inbuilt stabilisers versus frequency of operations .................................................... 22

2.3 Instruments for market operations …................................................................ 22

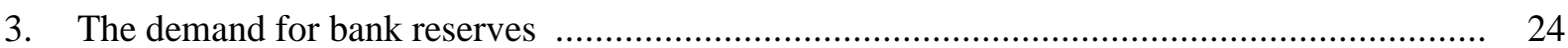

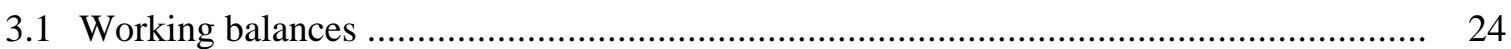

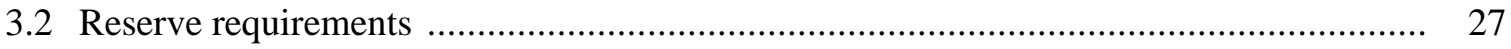

4. The supply of bank reserves: liquidity management …................................................... 36

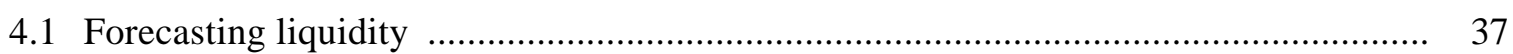

4.2 Discretionary market operations and standing facilities ......................................... 40

5. The supply of bank reserves: signalling and tactics ................................................... 50

5.1 How much transparency with respect to operating targets? ...................................... 50

5.2 Varieties of signalling strategies .......................................................................... 51

5.3 Why does signalling work? .............................................................................. 57

5.4 Choice of maturities and volatility revisited …......................................................... 58

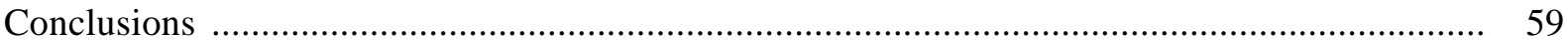

Annex I: Sources and uses of bank reserves: some cross-country statistics ............................... 62

Annex II: Reserve requirements: additional information ....................................................... 68

Annex III: Standing facilities: additional information ............................................................ 70

Annex IV: Discretionary operations: additional information ................................................. 71

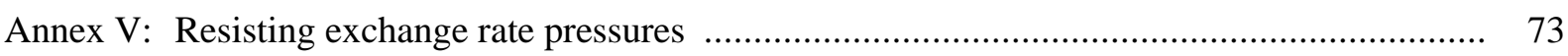

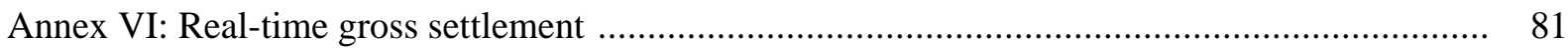




\section{Boxes}

Box 1

Stylised sources and uses of bank reserves 7

Box 2

A taxonomy of central bank operations

Box 3

Reserve requirement accounting 28

Box 4

Institutions subject to reserve requirements 68

\section{Tables}

Table 2.1 Key features of operating procedures 11

Table 2.2

Standing facilities 18

Table 2.3

Relationship between volatilities in policy rate spreads: simple regressions 21

Table 2.4

Discretionary operations: an overview 23

Table 3.1

Institutional arrangements and settlement balances 25

Table 3.2

Functions of reserve requirements 27

Table 3.3

Reserve requirements: size and seigniorage income 29

Table 3.4

Main features of reserve requirements 30

Table 4.1

Features of the forecasting process 38

Table 4.2

Relationship with the Treasury: lending and deposits 39

Table 4.3

Standing facilities: market ceiling 42

Table 4.4

Standing facilities: market floor .

Table 4.5

Standing facilities: below market .

Table 4.6

Discretionary operations 46

Table 5.1

Signalling mechanisms 52

Table 5.2 Disclosed information about market operations 54

Table A.I.1 Basic sources and uses of bank reserves 63

Table A.I.2 Breakdown of the net autonomous position 64

Table A.I.3 Breakdown of the net policy position: standing facilities and discretionary (market) operations

Table A.I.4 Breakdown of the net policy position: standing facilities ..... 66

Table A.I.5

Breakdown of the net policy position: discretionary (market) operations 67

Table A.II.1 Reserve requirements: eligible liabilities and ratios 69

Table A.III.1 Standing facilities: additional information 70

Table A.IV.1 Discretionary operations: counterparties 71

\section{Graphs}

Graph $1.1 \quad$ The demand for working balances ..............................................................

Graph 1.2 The demand for bank reserves under reserve requirements ............................... 5 
Graph 2.1

Key official and market interest rates

Graph 2.2

Volatility of policy rate spreads

Graph 3.1 Volatility of the overnight and three-month interest rate in the United States

Graph 3.2

The buffer function of averaging provisions

Graph $3.3 \quad$ End-of-maintenance-period effects on interest rates

Graph 3.4

Patterns of reserve accumulation

Graph A.V.1

Liquidity management during the 1992 ERM turbulence

Graph A.V.2 Interest rate setting at times of exchange rate pressure

\begin{tabular}{|c|c|c|c|c|c|}
\hline \multicolumn{6}{|c|}{ List of common symbols used in the tables } \\
\hline$*$ & $=$ & yes & AU & $=$ & Australia \\
\hline [blank] & $=$ & no & AT & $=$ & Austria \\
\hline. & $=$ & not available & $\mathrm{BE}$ & $=$ & Belgium \\
\hline- & $=$ & not applicable, non-existent & $\mathrm{CA}$ & $=$ & Canada \\
\hline$\Delta$ & $=$ & change (first difference) & FR & $=$ & France \\
\hline $\mathrm{O} / \mathrm{N}$ & $=$ & overnight (day-to-day) & $\mathrm{DE}$ & $=$ & Germany \\
\hline S-T & $=$ & short-term & IT & $=$ & Italy \\
\hline $\mathrm{d}$ & $=$ & day & JP & $=$ & Japan \\
\hline $\mathrm{W}$ & $=$ & week & NL & $=$ & Netherlands \\
\hline $\mathrm{m}$ & $=$ & month & ES & $=$ & Spain \\
\hline $\mathrm{y}$ & $=$ & year & SE & $=$ & Sweden \\
\hline av. & $=$ & on average & $\mathrm{CH}$ & $=$ & Switzerland \\
\hline CL & $=$ & collateralised loan & UK & $=$ & United Kingdom \\
\hline FXS & $=$ & foreign exchange swap (purchase or sale) & US & $=$ & United States \\
\hline I & $=$ & operation in the interbank cash market & & & \\
\hline OT & $=$ & outright transaction, secondary market & & & \\
\hline $\mathrm{RP}$ & $=$ & reversed purchase (repo) & & & \\
\hline RRP & $=$ & reversed sale (reverse repo) & & & \\
\hline $\mathrm{RT}$ & $=$ & reversed transaction (repo or reverse repo) & & & \\
\hline $\mathrm{S}$ & $=$ & $\begin{array}{l}\text { sale of (central bank) short-term deposits or } \\
\text { short-term government paper }\end{array}$ & & & \\
\hline $\mathrm{T}+\mathrm{i}$ & $=$ & $\begin{array}{c}\text { the value date of the transaction is i days after } \\
\text { the trade date }(\mathrm{T})\end{array}$ & & & \\
\hline TGD & $=$ & transfer of government deposits & & & \\
\hline$\approx$ & $=$ & approximately equal to & & & \\
\hline $\bar{R}^{2}$ & $=$ & adjusted R-squared & & & \\
\hline SEE & $=$ & standard error of the equation & & & \\
\hline (.) & $=$ & $\begin{array}{c}\text { figures in brackets below coefficient estimates } \\
\text { are standard errors }\end{array}$ & & & \\
\hline$*$ & $=$ & statistically significant at the $10 \%$ level & & & \\
\hline$* *$ & $=$ & statistically significant at the $5 \%$ level & & & \\
\hline **** & $=$ & statistically significant at the $1 \%$ level & & & \\
\hline
\end{tabular}





\section{Introduction $^{1}$}

In recent years monetary policy operating procedures have continued to evolve in the light of changes in the structure and workings of financial markets as well as in the broader economic and political environment. Since the Economists' Meeting last visited the subject in $1985,{ }^{2}$ central banks have strengthened the market orientation of policy implementation, cut reserve requirements, widened the range of available instruments, increased the flexibility of liquidity management, sharpened the focus on interest rates as operating targets, improved the transparency of policy signals and shortened the maturity of interest rates serving as the fulcrum of policy. While these trends have resulted to some extent in a continuation of the process of convergence dating back to at least the 1970s, significant differences still exist across countries.

This background paper reviews current monetary policy implementation procedures within a common framework in order to highlight similarities and remaining differences across countries. It also provides some information about their evolution in recent years and suggests possible explanations for the main forces underlying the observed changes. The analysis draws heavily on the responses to the factual questionnaire sent to participants and on further statistical information requested.

The paper is organised as follows. Section 1 outlines the conceptual framework underpinning the analysis. Section 2 offers a very brief overview of existing arrangements, focusing only on the main defining features of national set-ups. Section 3 examines in more detail the characteristics of the demand for bank reserves, treating separately cases in which this is primarily determined by settlement balance needs and those in which reserve requirements still play a major role. Sections 4 and 5 then analyse the supply of bank reserves, broadly defined. Section 4 deals essentially with liquidity management issues, that is, with how central banks go about meeting the demand for bank reserves through adjustments in the supply. It looks in particular at the forecasting process and at the basic features and functions of discretionary market operations and standing facilities. Section 5, by contrast, examines the communication strategies through which central banks attempt to influence and guide market rates. In this context, signalling mechanisms and tactics are considered in some detail. The conclusions summarise the key points emerging from the analysis.

A number of annexes complement the paper. Some of these simply present additional information which was provided in the responses to the questionnaire but which, for reasons of space or compactness, could not be included in the main text. Annex V discusses how operating procedures are adapted and perform at times of severe exchange rate pressure, when they are tested to the full. Annex VI considers the implications of the general shift towards real-time gross settlement at present under way.

1 The information contained in this paper relates to the arrangements in place in September 1996. This work could not have been produced without the cooperation of the central banks of the countries covered. I would like to thank Joseph Bisignano, Junichi Iwabuchi, Robert Lindley and Paul Van den Bergh for their comments, Angelika Donaubauer, Philip Hainaut and Gert Schnabel for statistical assistance and Stephan Arthur for preparing the graphs and overseeing the publication. Special thanks go to John Kneeshaw for invaluable discussions on the issues covered.

2 "Changes in money-market instruments and procedures: objectives and implications", CB 385, Bank for International Settlements, Basle, March 1986. 


\section{Conceptual underpinnings}

Currently virtually all the central banks in the countries considered in this paper implement monetary policy through market-oriented instruments which they gear to influencing very short-term interest rates. ${ }^{3}$ They do so largely by determining the conditions that equilibrate supply and demand in the market for bank reserves (bank deposits with the central bank). It is in this relatively unglamorous and often obscure corner of the financial markets that the ultimate source of the central banks' power to influence economic activity resides.

The market for bank reserves is a special one indeed. The central bank is a monopolist supplier which can also directly affect demand. It can, and often does, affect it, for instance, by setting reserve requirements or by helping to shape the characteristics of, and by operating, key interbank settlement systems. Moreover, the way in which central banks attain their objectives relies on a varying mixture of stated and unstated rules, conventions and communication strategies which are bewildering to the uninitiated. ${ }^{4}$

Despite the complexity and country-specificity of operating procedures, a stylised framework can throw light on how the main features of policy implementation vary with institutional arrangements. ${ }^{5}$ The resulting paradigms provide a useful compass for the more detailed analysis that follows. It is helpful to consider the demand for and supply of bank reserves in turn.

\subsection{The demand for bank reserves}

The characteristics of the demand for bank reserves depend crucially on whether binding reserve requirements are in place.

\subsubsection{Working balances}

In the absence of a binding reserve requirement the demand for bank reserves is essentially a demand for settlement (working) balances. While banks are legally required to settle on the books of the central bank only in a few cases, such as Canada and Australia, they generally do so for several reasons. Prominent among these are the direct access to the ultimate source of liquidity in the system, the reduction in credit risk resulting from settlement in a risk-free medium and competitive considerations, given that the central bank is a neutral participant, and at times even arbiter, in the market.

Settlement balances clearly have a high cost when, as is generally the case, they bear no interest. In this case, ending the day with a positive working balance means incurring an opportunity cost equivalent to the overnight (day-to-day) rate. The main reason why a bank would willingly aim at holding, on average, such positive balances is precautionary, viz. the risk of having to incur a penalty over the market rate owing to the inability to meet its settlement obligations with its existing balance at the central bank. This penalty may take the form of premia on prevailing overnight rates, rationing in the interbank market as limits to credit lines are hit and, finally, penal and possibly uncertain interest rate costs or quantitative restrictions on borrowing from the central bank itself.

3 A partial exception is the Swiss National Bank, whose main focus is the quantity of bank reserves.

4 In addition, it is not uncommon for interbank markets to be dominated by relatively few players, especially with regard to interbank settlement flows. This can have a considerable influence on the process through which the relevant interest rate, quantities and distribution of reserves are determined in the system. It raises the possibility of strategic interactions between the central bank and market players and between market players themselves. Moreover, it puts a premium on the role of conventions and non-market mechanisms.

5 This is an adaptation of the framework illustrated in J.T. Kneeshaw and P. Van den Bergh (1989): "Changes in central bank money market operating procedures in the 1980s", BIS Economic Papers, No. 23, Basle, January. 


\section{Graph 1.1 \\ The demand for working balances}

Panel A: No interest rate sensitivity

Panel B: Small interest rate sensitivity
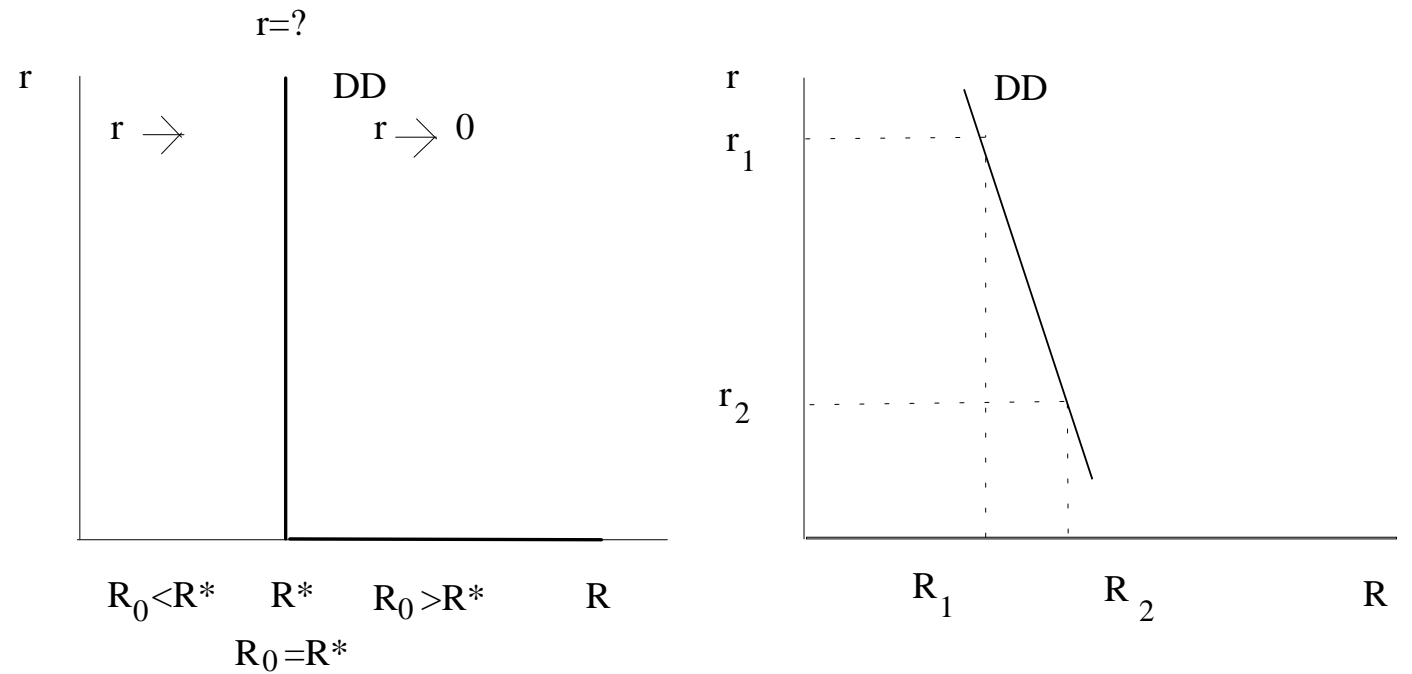

Panel C: Instability

\section{Comments:}

Panel A: The interest rate is either indeterminate $\left(\mathrm{R}_{0}=\mathrm{R}^{*}\right)$, tends to zero $\left(\mathrm{R}_{0}>\mathrm{R}^{*}\right)$ or to infinity $\left(\mathrm{R}_{0}<\mathrm{R}^{*}\right)$.

Panel B: Small changes in the supply of bank reserves $\left(R_{1}\right.$ to $\left.R_{2}\right)$ result in large changes in the interest rate $\left(r_{2}\right.$ to $r_{1}$ ).

Panel C: Given a low interest rate sensitivity, instability $\left(\mathrm{DD}_{1}\right.$ to $\left.\mathrm{DD}_{2}\right)$ results in large changes in the interest rate $\left(r_{2}\right.$ to $\left.r_{1}\right)$ for a given supply of reserves $\left(R_{1}\right)$. Actively providing reserves $\left(\mathrm{R}_{1}\right.$ or $\left.\mathrm{R}_{2}\right)$ can stabilise the interest rate.

Role of signalling:

In case A, signalling can help to focus expectations on a particular interest rate within the range of indeterminateness.

As a result, the demand for working balances is largely determined by the institutional and operational characteristics of payments and settlements and by the terms and conditions of central bank late-day assistance. In general, banks would tend to keep their holdings of working balances to a minimum. ${ }^{6}$ Indeed, where, as is often the case, the settlement system provides for a period for

6 If the central bank allows banks to overdraw their central bank accounts on attractive terms relative to the market, they may even target a "negative" balance, that is, they may target to be overdrawn. This is the case in the Netherlands. 
borrowing/lending among participants after the positions become known, the need for any precautionary holdings is much reduced, if not eliminated: banks would then target (approximately) zero balances.

More importantly, and for much the same reasons, the demand for settlement balances is likely to be very insensitive to changes in the overnight rate over its typical range of variation (Graph 1.1, Panels A and B). ${ }^{7}$ Reductions in this rate, for example, would hardly in themselves entice banks into willingly increasing their holdings. The demand could also be unstable, especially at the aggregate level, if banks failed actively to manage their positions and in the presence of technical or behavioural impediments to a smooth redistribution of reserves in the system (Panel C).

A very interest inelastic, and possibly unstable, demand for working balances calls for an active management of the supply of liquidity by the central bank on a daily basis if large fluctuations in the overnight rate are to be avoided (Panel C). It also puts a premium on signalling mechanisms aimed at guiding the rate over the regions where it may, in effect, be largely indeterminate.

\subsubsection{Reserve requirements}

Two preconditions must be fullfilled for reserve requirements to be the binding factor in determining the (marginal) demand for reserves. First, it should be possible to use the reserve requirement holdings to meet settlement needs. Second, the amount of reserves banks need to hold to comply with the reserve requirement should exceed their working balance targets. Clearly, these conditions cannot be met on those days when the reserve requirement calls for a specific amount of reserves to be attained. On those days, the factor influencing the marginal demand is the working balance (excess holdings) target (Graph 1.2, Panel A). The conditions can be met only if some averaging provision exists, allowing individual banks to offset deficiencies with surpluses over a given period. In addition, the size of the deficiencies that a bank would wish to run should not be such as to infringe the minimum working balance needs. ${ }^{8}$

When reserve requirements are the binding factor, averaging provisions can act as a buffer for the overnight rate. At any given point in time in the averaging ("maintenance") period, banks would tend to be indifferent about the amount of reserves they held as long as: (a) the opportunity cost of holding them was expected to change little over the remainder of the period; (b) they held those expectations with little uncertainty or were not much concerned about it (low "risk aversion"). Thus, with fixed or zero-remunerated reserve requirements, they would be indifferent if they were confident that no significant increases/decreases in the overnight rate would take place. ${ }^{9}$ Under these conditions, the demand for reserves would be very elastic around the level of the rate expected to prevail in the future (Panel B). ${ }^{10}$ The high sensitivity of demand to the interest rate would help to cushion the impact of changes in the supply of reserves on the overnight rate (same graph).

The extent to which reserve requirements can act as a buffer declines during the maintenance period. As time passes, the room for manoeuvre is increasingly constrained by the cumulated reserve position, since the number of days available for offsetting any excess/deficiency falls and the size of the corresponding adjustment rises. Similarly, banks would be less willing to arbitrage, as the risks of being unable to offset positions at prevailing market rates would rise. This

7 This statement should be read as reflecting typical situations; the specific characteristics will depend on the factors mentioned in the previous paragraph.

8 More correctly, for given expectations about the evolution of the overnight rate, it should not be such as to make considerations regarding working balance needs influence desired holdings for that day.

9 If the remuneration was fixed as a roughly constant margin below the prevailing overnight rate, banks would tend to be indifferent regardless of the expected path of the overnight rate.

10 Under the extreme assumptions of risk neutrality and uniform expectations, the demand would be infinitely elastic at the expected rate. 
Panel A: End of maintenance period

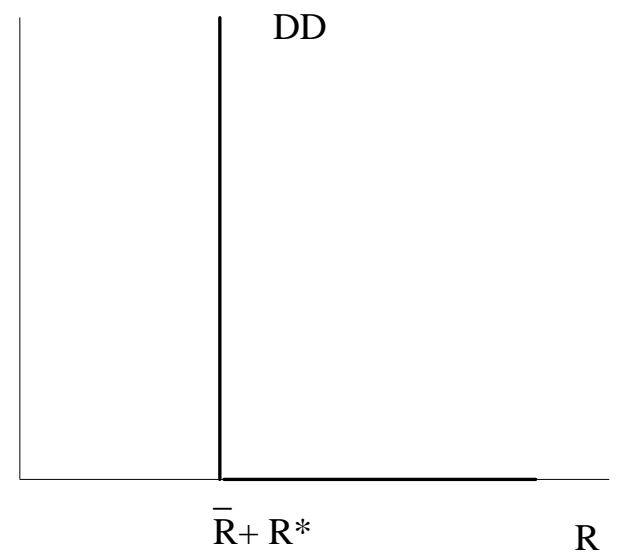

Panel C: Time-varying sensitivity

r

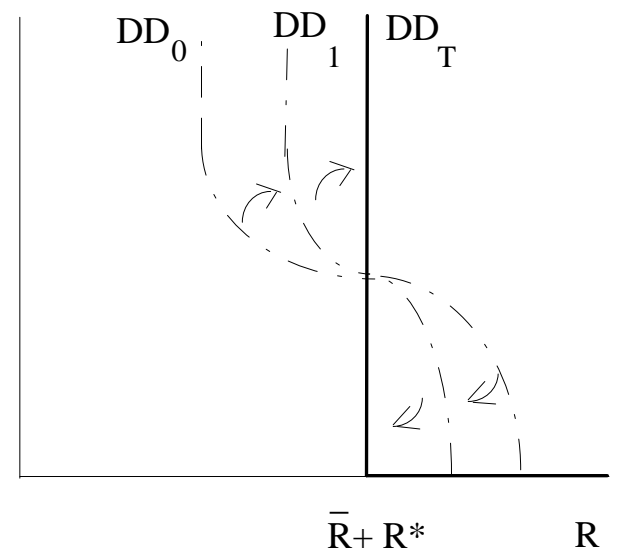

Panel B: Beginning of maintenance period; extreme case

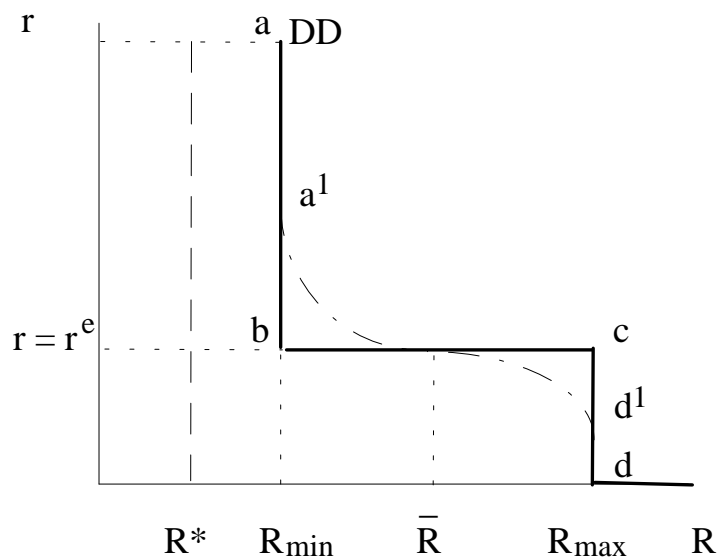

Panel D: Instability

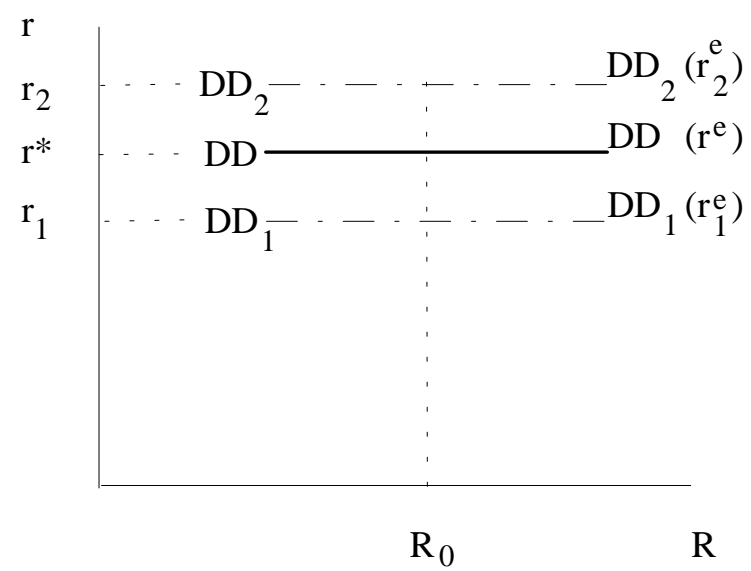

Panel A: At the end of the maintenance period the demand for bank reserves converges to that for working balances $\left(\mathrm{R}^{*}\right)$ plus whatever amount is necessary to meet the average reserve requirement. (This will be equal to the average requirement itself $(\bar{R}$, as assumed in the graph) in the case in which the banks are already on target in the preceding period.)

Panel B: Within a range determined by the level of requirement and length of the averaging period $\left(R_{\min }-R_{\max }\right)$ as long as the minimum bound exceeds the demand for working balances $\left(R^{*}\right)$, the demand for bank reserves will be very elastic $\left(a^{1}, d^{1}\right)$, and in the extreme perfectly $(b, c)$ elastic, at the level of the overnight rate expected to prevail during the period $\left(\mathrm{r}^{\mathrm{e}}\right)$.

Panel C: Over time, the demand for reserves converges to that ruling at the end of the maintenance period $\left(\mathrm{DD}_{0}\right.$ to $\left.\mathrm{DD}_{\mathrm{T}}\right)$.

Panel D: Changes in the interest rate expected to prevail $\left(\mathrm{r}^{\mathrm{e}}{ }_{1}\right.$ to $\left.\mathrm{r}_{2}\right)$ result in similar changes in the market rate $\left(r_{1}\right.$ to $\left.r_{2}\right)$ for any given supply of reserves $\left(R_{0}\right)$. 
suggests that the interest elasticity of the demand for reserves would tend to decline, especially towards the end of the maintenance period, converging on the last day to that of working balances (Panel C). ${ }^{11,12}$

These arguments suggest that, ceteris paribus, reserve requirements with averaging provisions call for a less active day-to-day management of liquidity by the central bank. The extent to which this is true will depend on their level, on the length of the averaging period and on banks' willingness to arbitrage expected changes in the overnight rate over time. At the same time, averaging introduces a new potential source of instability in the demand for reserves, viz. volatile expectations about the path of the overnight rate (Panel D). ${ }^{13}$ If anything, this makes signalling even more important as a mechanism for limiting volatility in that rate.

\subsection{The supply of bank reserves}

Given the characteristics of the demand for bank reserves, the central bank's task is to regulate the supply in order to achieve its interest rate or quantitative objectives. There are essentially two aspects to this task. The first is how to go about adjusting the liquidity position of the system, balancing supply with demand ("liquidity management" proper). The second is how to reinforce any influence that liquidity adjustments may have on interest rates through specific communication strategies vis-à-vis market participants (essentially "signalling mechanisms").

Liquidity management involves offsetting to the extent necessary the autonomous (net) sources of reserves ("liquidity"), ${ }^{14}$ which imply changes in the other items of the central bank's balance sheet. While varying somewhat from country to country, these sources include primarily increases in net foreign assets resulting, for example, from foreign exchange intervention; increases in (net) lending to the government; changes in other residual net assets, such as float or capital and reserves (other than those arising from valuation effects; see Box 1); and reductions in currency in circulation ("cash"). ${ }^{15}$ An autonomous surplus (deficit) can be said to exist if autonomous factors lead to a net increase in liquidity withdrawal. ${ }^{16}$

On an ex post basis, the sum of the net liquidity created through the autonomous channels and through central bank operations represents the net addition to bank reserves. On an ex ante basis, it is often useful to think of the difference between the autonomous creation of reserves and the amount demanded as the balance that has to be met by central bank operations (the net liquidity position). An integral part of liquidity management is precisely the forecast of the net liquidity position, which provides an ex ante basis for the assessment of the need to effect operations (Section

11 Plus whatever amount is necessary to meet the reserve requirement. In fact, the speed of convergence would depend on the actual liquidity shocks hitting the system. For instance, in the extreme case in which on the first day of the maintenance period the supply of liquidity was so large as to imply reserve holdings of a size equivalent to working balances for the rest of the period to meet the requirement, any flexibility would be immediately lost.

12 Given this convergence, assuming that the demand for working balances is effectively insensitive to interest rates, the rate on the last day would again be largely indeterminate. This implies a considerable potential for instability in the absence of clear signalling. Given intertemporal arbitrage, once the expected interest rate for the end of the period is determined, the equilibrium expected interest rates for the rest of the period can be derived.

13 Strictly speaking, this would also occur in the presence of a demand curve for working balances which was completely insensitive to the current overnight rate. If the central bank cared only about longer rates, the overnight rate would be free to adjust through arbitrage to expectations which would only be anchored at those longer maturities.

14 Henceforth the terms "bank reserves" and "liquidity" will be used interchangeably.

15 Conceptually, one may wish to add to the list also those standing facilities at below market rates activated on demand by banks.

16 Sometimes the term "structural" surplus/deficit is alternatively used. However, it would seem preferable to restrict such a term to situations where the surplus/deficit from autonomous factors is highly persistent over time. 
4). If the supply falls short of the demand, a "net liquidity deficit (shortage)" is generally said to exist, in which case the central bank needs to inject liquidity; in the event of a "net liquidity surplus", it needs to withdraw liquidity.

\section{Box 1 \\ Stylised sources and uses of bank reserves}

Consider an extremely stylised balance sheet of the central bank, with " $\Delta$ " denoting the change in the relevant variable.

\begin{tabular}{|lc|}
\hline \multicolumn{2}{|c|}{ Balance sheet of the central bank } \\
Assets & Liabilities \\
$\Delta$ Net foreign assets & $\Delta$ Cash (notes) \\
$\Delta$ Net lending to the government & $\Delta$ Bank reserves \\
$\Delta$ Net lending to banks & \\
$\Delta$ Other net assets & \\
\hline
\end{tabular}

The item "Other net assets" would typically include changes in capital and reserves (negative sign), float and changes in the valuation of assets. Assume that all the channels for influencing liquidity under the control of the monetary authorities over the relevant horizon have been grouped under " $\Delta$ Net lending to banks" (or the "net policy position"). If so, the other items on the asset side are purely "autonomous". Then, rearranging terms:

Autonomous liquidity position $(+$, injection/-, withdrawal) $=$

$\Delta$ Net foreign assets $+\Delta$ Net lending to the government

$+\Delta$ Other net assets $-\Delta$ Cash

and:

$\Delta$ Bank reserves $=$ Autonomous liquidity position + Net policy position

From the viewpoint of liquidity management, it is generally useful to think in ex ante terms. Replacing " $\Delta$ Bank reserves" by the quantity demanded (implicitly at some desired rate) and rearranging terms we have:

Net liquidity position $=$ Autonomous liquidity position $-\Delta^{\mathrm{d}}$ Bank reserves

The net liquidity position is the mirror image of the amount of reserves that the central bank should provide through its operations to balance the market (at the desired interest rate). In turn, bank reserves can be split into two items: reserve requirements (if any) and (net) excess reserves or working balances, depending on circumstances.

Annex I provides a description of changes in national central bank balance sheets along these lines. 


\section{Box 2}

\section{A taxonomy of central bank operations}

The central bank's mechanisms, other than reserve requirements, for adjusting the liquidity (bank reserves) in the market (i.e. making up "net lending to banks" or the "net policy position") can be broken down according to several criteria: by technical form of the instrument, by the degree of discretion exercised by the central bank in its use and by the frequency of its employment.

A possible breakdown by instrument, used in what follows, is:

1. Central bank lending: loans and advances, almost exclusively against collateral, not granted through tenders. Defined here to include also the corresponding discounting of securities.

2. Reversed transactions against domestic currency assets: purchases (sales) of assets reversed at some point in the future; equivalent in cash-flow terms to collateralised lending (borrowing). From the viewpoint of the central bank, temporary purchases ("repos") inject liquidity, temporary sales ("reverse repos") withdraw it.

3. Reversed transactions against foreign currency assets: equivalent to the above but against assets denominated in foreign currency. Foreign exchange swaps are the most common. They can be used either to inject liquidity (temporary purchases of foreign currency) or to withdraw it (temporary sales of foreign currency).

4. Outright transactions in the secondary market: firm purchases/sales of outstanding securities.

5. Issue of short-term paper: sale of central bank paper in the primary market. Defined also to include issues by the central bank of government paper on its behalf performing a similar function.

6. Operations in the interbank market: interventions in the interbank cash market via the collection of deposits and (possibly unsecured) lending.

7. Transfers of government deposits: a transfer from the central bank's books to those of banks injects liquidity; a transfer in the opposite direction reduces it.

Operations 2 to 6 are referred to as "market" operations.*

In terms of degree of discretion, a common distinction is between:

1. Standing facilities: operations activated on demand by market participants (mainly banks).

2. Discretionary operations: carried out at the discretion of the central bank.

In terms of frequency, transactions can be divided into:

1. Regular: occurring at a regular frequency, known in advance.

2. Irregular: the complementary case.

Typically, the distinction between regular and irregular operations is applied to market transactions only. Irregular operations (other than in the form of central bank lending) are sometimes known as "fine-tuning". Contrary to the common usage of the term, however, not all irregular (fine-tuning) operations are designed to modulate precisely the supply of reserves on a day-to-day basis with a view to balancing the market (see Section 4).

Sometimes the term "open market" is used even if, strictly speaking, the central bank may restrict the range of counterparties and/or not transact in the established private market.

In principle, central banks can equally meet net liquidity surpluses and shortages. Several central banks, however, prefer to operate with net deficits, as net creditors rather than debtors in the 
market. Quite apart from their possible influence on the marginal demand for reserves, reserve requirements can be aimed at raising the average demand, thereby possibly turning an autonomous surplus into a net liquidity deficit. In addition, in a number of systems the operation(s) setting the tone of policy can only inject liquidity ("asymmetric" systems). In this case, in order to ensure that the operation remains active, the central bank needs to drain any excess liquidity from the system. When reserve requirements are not in place or insufficient for the purpose, the central bank could then be withdrawing liquidity through some (market) transactions while injecting it through others, possibly even on the same day.

Liquidity can be adjusted either through transactions entered into at the discretion of the central bank or through standing facilities, which are activated on demand by market participants (Box 2). ${ }^{17}$ Either of these may be the effective marginal source of liquidity equilibrating the market. But by and large, and increasingly so, central banks have preferred to use discretionary operations to make the required adjustments in marginal liquidity. Correspondingly, they have tended to use standing facilities primarily as "safety valves" for end-of-day imbalances, as guideposts setting limits to the range of fluctuation of the overnight rate, or, in some cases, as sources of subsidised intramarginal liquidity (Graph 1.3, Panels A and B).

Graph 1.3

The supply of bank reserves

\section{Panel A: Bounds-setting standing facilities Panel B: Below-market (subsidised) facilities}
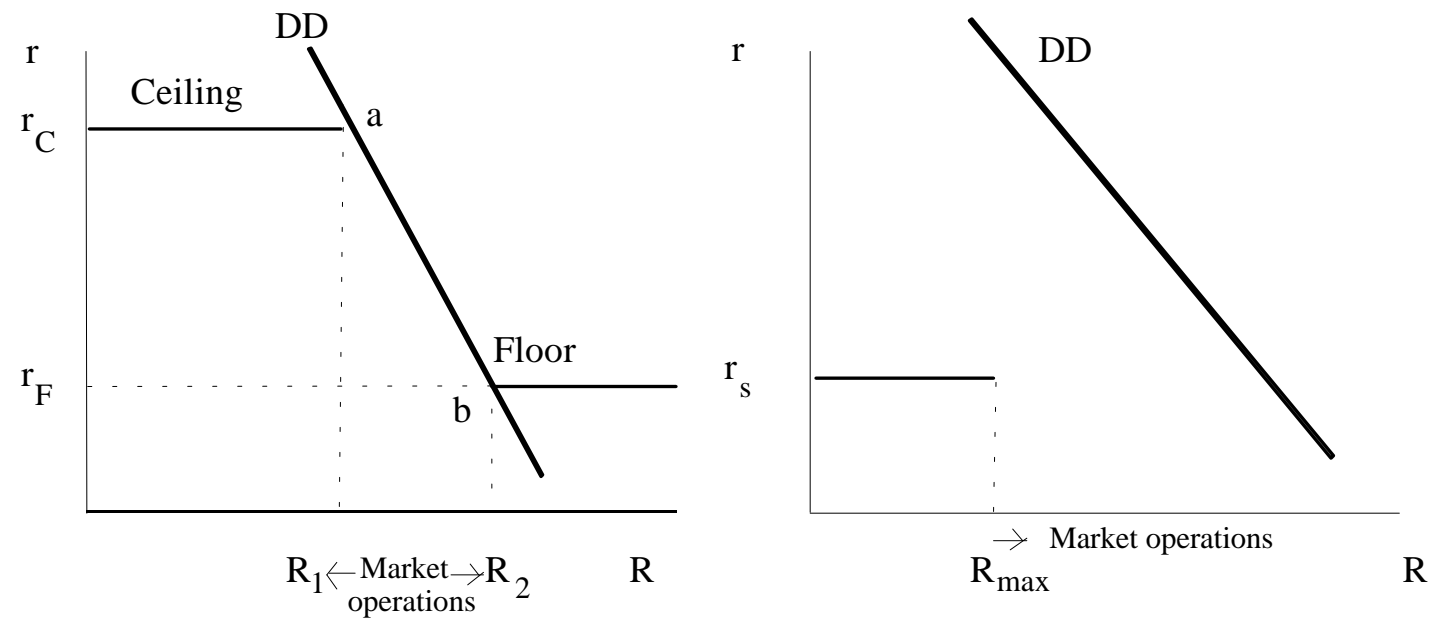

Panel A: The standing facility at $\mathrm{r}_{\mathrm{C}}$ sets a ceiling to the interest rate; the one at $\mathrm{r}_{\mathrm{F}}$ sets a floor. (Given the presence of the facilities, the demand curve will itself tend to be infinitely elastic at the corresponding rates $\mathrm{r}_{\mathrm{C}}, \mathrm{r}_{\mathrm{F}}$ ) Market operations can be used to affect the supply between $R_{1}$ and $R_{2}$. The points $R_{1}$ and $R_{2}$ shift with the demand curve.

Panel B: A below-market facility rations credit to the point $\mathrm{R}_{\max }$. As long as the demand for reserves exceeds supply at that rate, $\mathrm{r}_{\mathrm{S}}$ does not determine market rates; it merely provides inframarginal, comparatively cheap liquidity.

17 The distinction between the two need not map one-to-one into the type of instrument used. Reversed transactions such as repos, a typically discretionary instrument, may be offered on a standing basis, or discretion may be used in granting credit through a discount window. Similarly, a standing facility may at times be suspended and the volume of finance or other terms be subject to the discretion of the central bank. 
Discretionary operations typically take the form of either firm purchases/sales of securities or, more often, reversed transactions in domestic or foreign currency (Box 2). Especially in countries with reserve requirements and averaging provisions, a distinction is often made between regular and "irregular" transactions. Regular transactions typically aim at providing the bulk of liquidity needs; their timing and, sometimes, maturity are closely tied to the characteristics of the maintenance period. ${ }^{18}$ By contrast, irregular transactions are employed to make the necessary adjustments to the volume of liquidity as dictated by evolving circumstances.

Partly owing to the limited use of standing facilities and the characteristics of the demand for bank reserves, central banks rely on signalling mechanisms to guide market views of very short-term rates and hence to strengthen their influence over them (Section 5). These mechanisms may involve adjustments in quantities, but have increasingly taken the form of explicit references to specific interest rate levels. Such signals are sent through announcements of interest rate targets or bands, through the interest rates at which market, typically regular, operations are executed and/or through the posted rate on standing facilities.

\subsection{The operating target}

Much of the above discussion was conducted in terms of the behaviour of the overnight rate itself: this is the money market interest rate which is largely determined in the market for bank reserves and over which the central bank has the closest control. Yet the overnight rate need not be the main focus or reference for policy (the "operating objective or target"). The authorities may set their policy in relation to a quantity, such as the path of bank reserves themselves. Alternatively, they may focus on interest rates of a somewhat longer maturity, say one month. In either case, the previous analysis still holds. The main implication is that, ceteris paribus, greater volatility in the overnight rate would be accepted. In particular, if the central bank focused on somewhat longer rates, it would tend to tolerate unexpected movements in the overnight rate provided they did not undermine the attainment of the operating objective.

\section{A bird's eye view of arrangements}

The foregoing framework can now be used to review the main characteristics of national monetary policy procedures. This section discusses the choice of policy rates and operating targets, the means for stabilising interest rate fluctuations and the main instruments used. A more detailed discussion of the various elements follows in the next three sections. For the sake of comparison, an effort is made to standardise the presentation as far as possible. This may mean that certain features of the procedures may be discussed in ways that are not entirely familiar to the central banks concerned.

\subsection{Policy rates and operating targets}

As regards the key policy rate, that is, the interest rate which best captures the authorities' policy intentions, countries fall into three groups (Table 2.1 and Graph 2.1). In the first, comprising the United States, Japan, Canada and Australia, the most representative policy variable is the overnight interbank rate itself. These are countries where tender rates on central bank discretionary operations, as a rule, play no independent signalling role. Signalling strategies differ somewhat in the four cases. In the United States, since February 1994 the central bank has explicitly announced a federal funds target; target announcements have been made in Australia since January 1990. In Canada, since June 1994 the central bank has established an explicit 50 basis points operating band,

18 Not all regular operations are used for this purpose (Section 4). 
Table 2.1

Key features of operating procedures

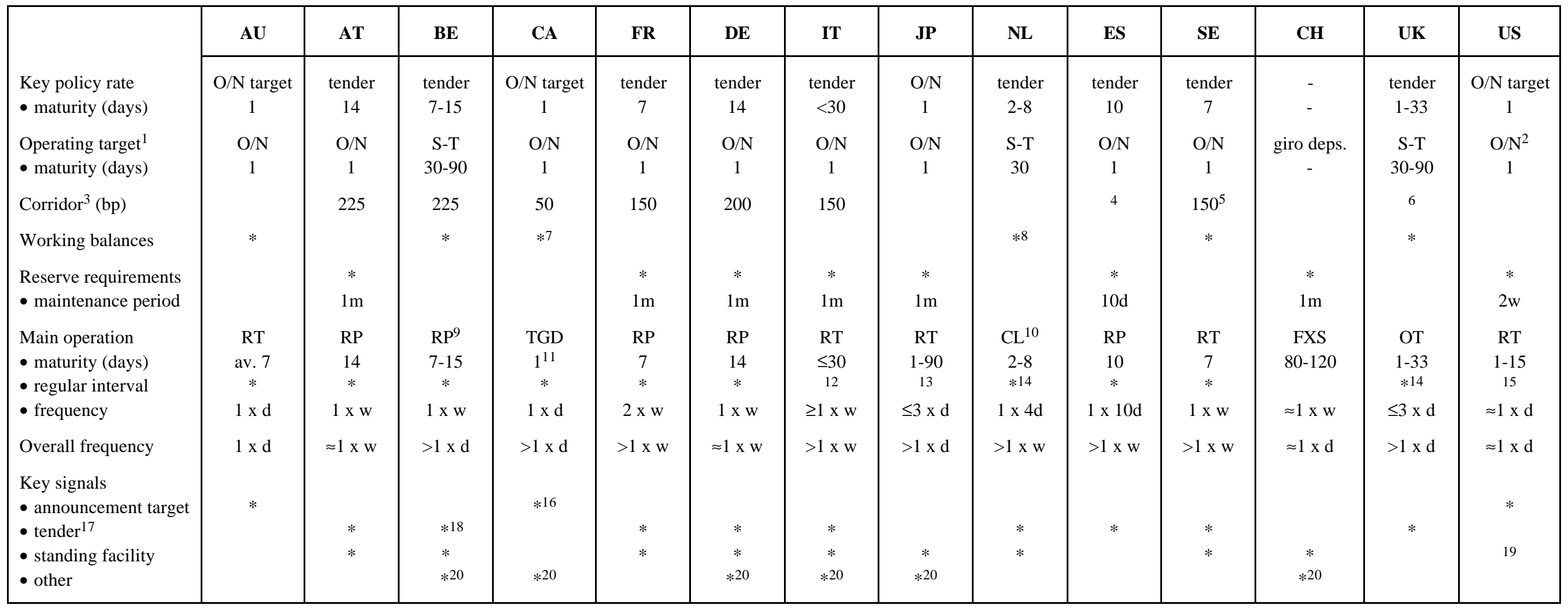

Note: For an explanation of the common symbols used in this and subsequent tables, see the list following the Contents.

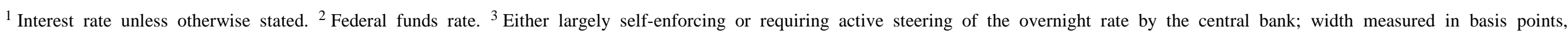

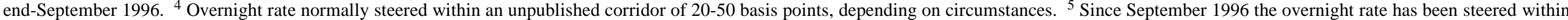

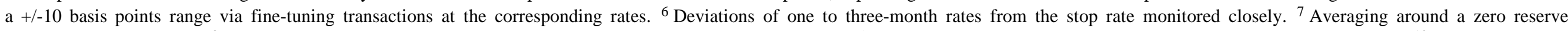

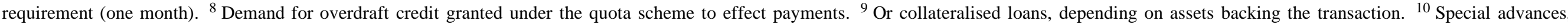

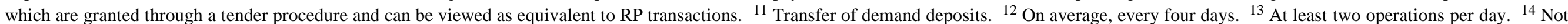

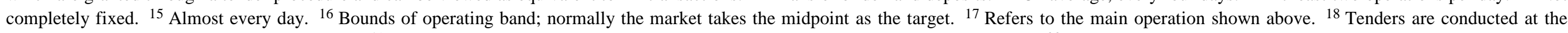
central rate, which can be changed at any time. ${ }^{19}$ The discount rate had a clear signalling role until the announcement of the target rate. ${ }^{20}$ Largely quantity signals (Section 5). 
Graph 2.1a

\section{Key official and market interest rates}
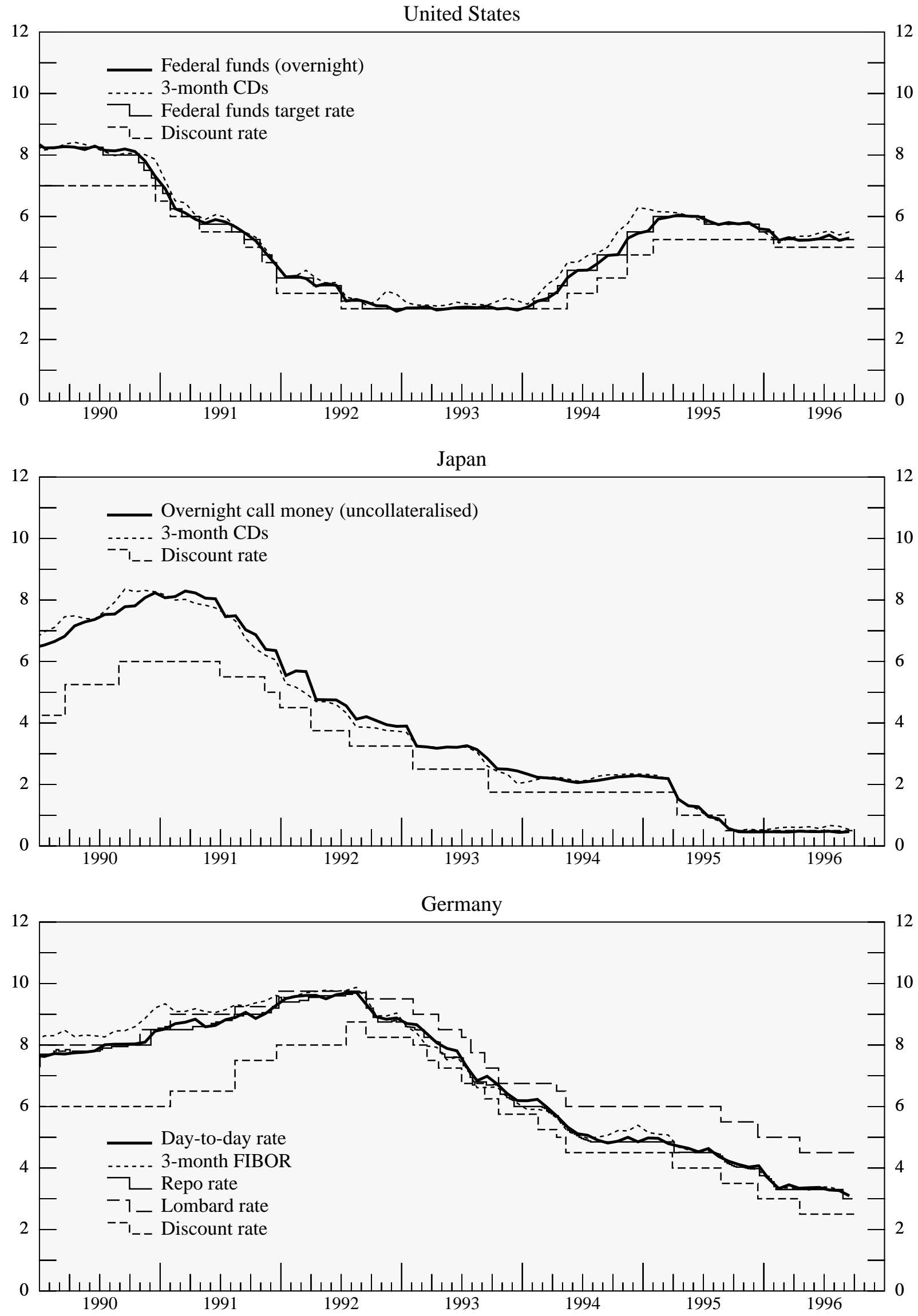
Graph 2.1b

\section{Key official and market interest rates}
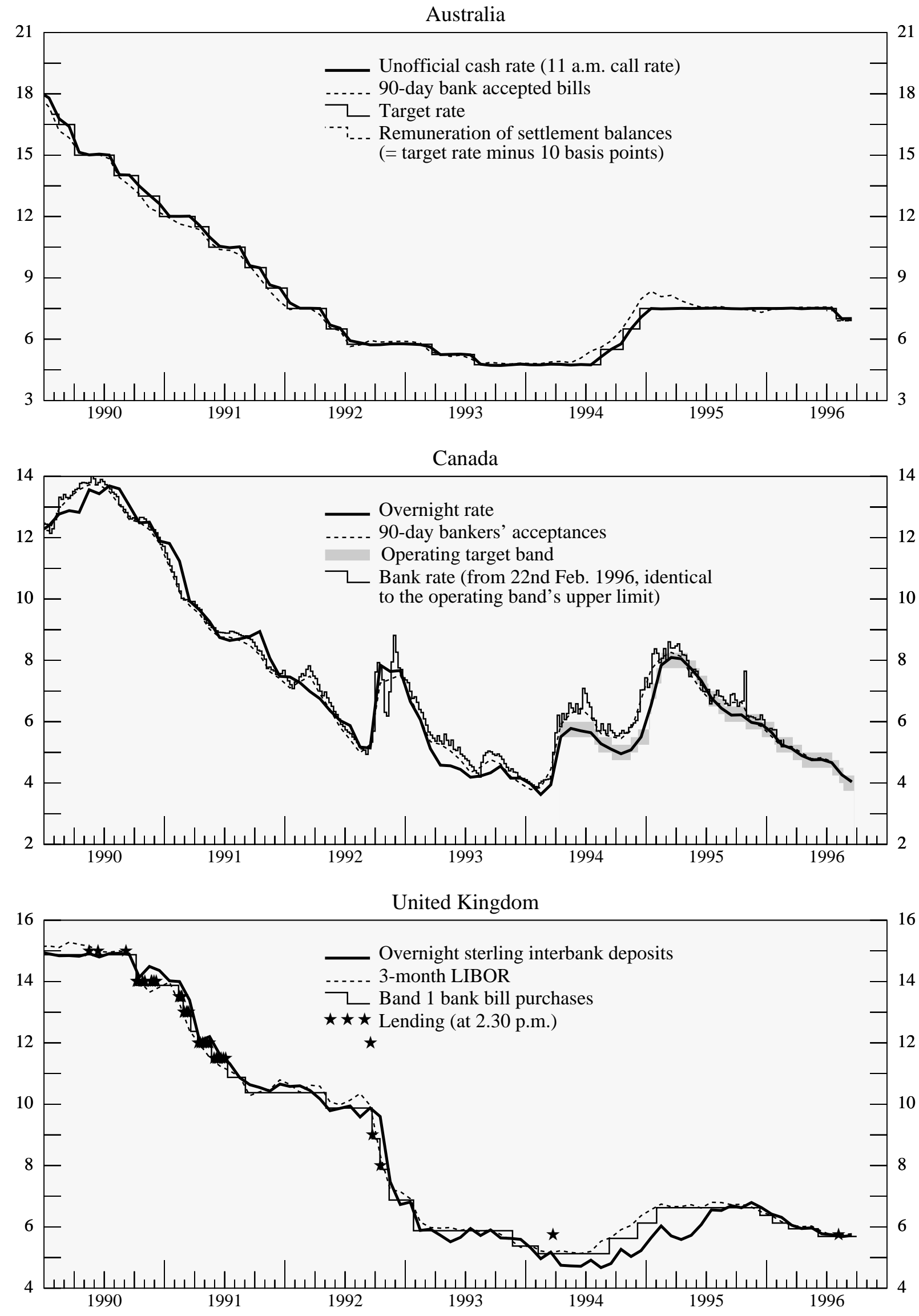
Graph 2.1c

\section{Key official and market interest rates}
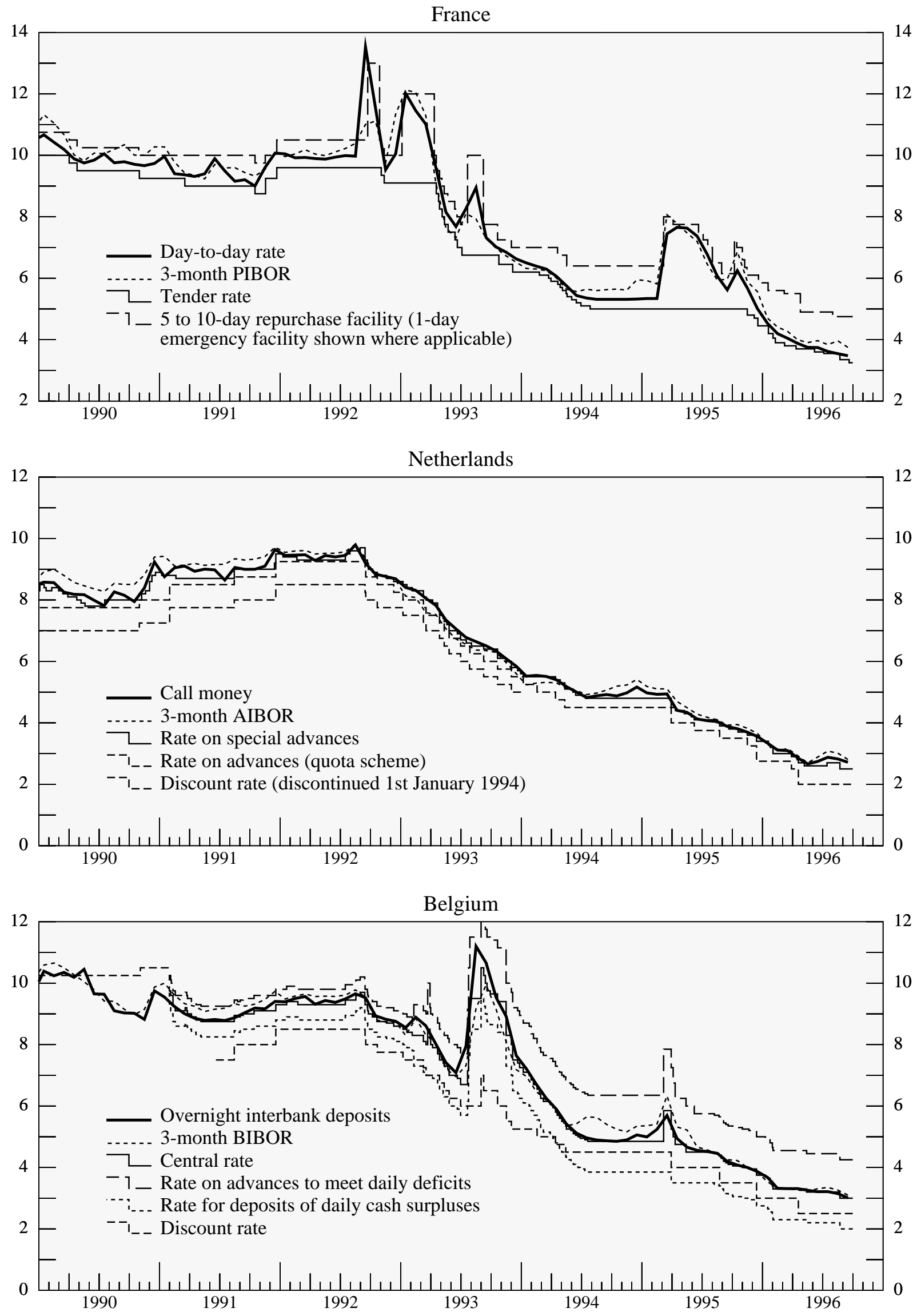
Graph 2.1d

\section{Key official and market interest rates}
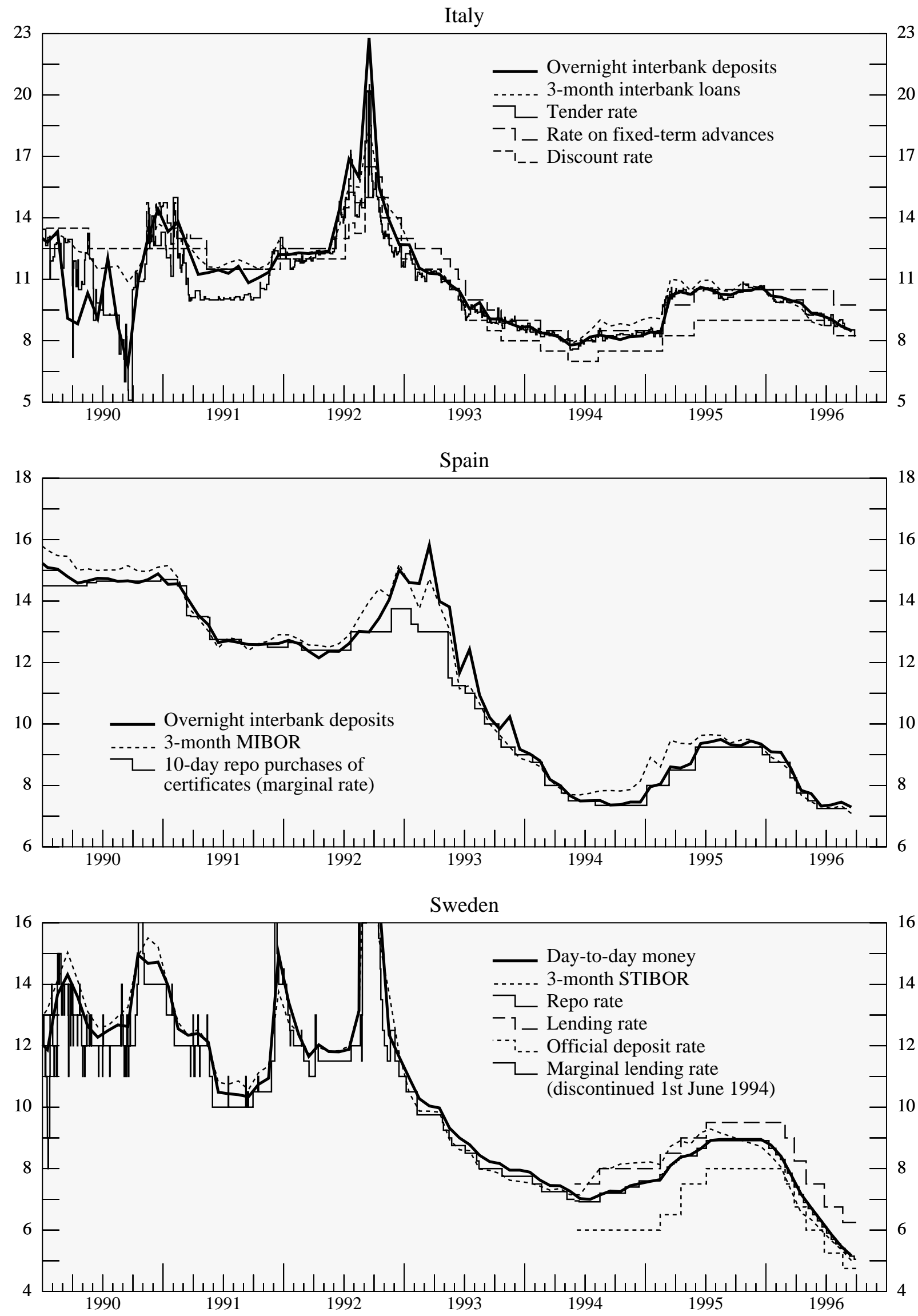
Graph 2.1e

\section{Key official and market interest rates}
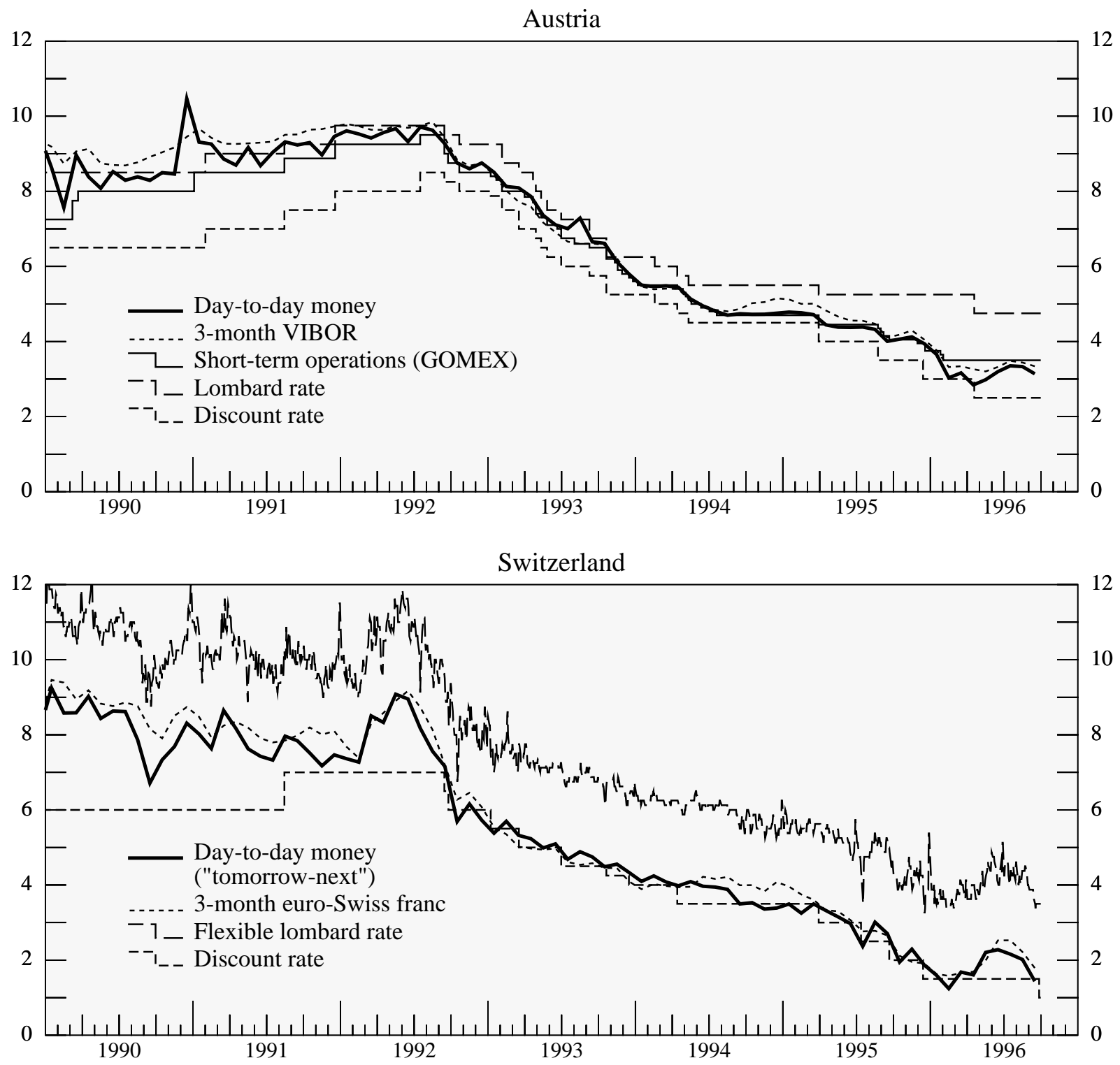

Explanatory comparative key:

Overnight rate

...... 3-month money market rate

乙 Policy rate

Operating target band

$\star \star \star$ High-profile policy rate

-1 - Market ceiling rate

-..... Market floor rate

- - I_ _ Below-market rate 
communicated and validated by the offer to enter into repurchase transactions ${ }^{19}$ at those rates. In contrast, in Japan the central bank does not announce a specific target for the overnight call rate. However, since 1995 its policy of communicating policy changes through quantity signals, sometimes reinforced by changes in the discount rate, has been supplemented by statements concerning broadly desired levels for the operating objective (Section 5).

In all the remaining countries, except Switzerland, the key policy variable is the tender rate applicable to regular operations, mainly repurchase transactions. The maturity of those operations lies mostly between one and two weeks, but could be as short as one to two days or as long as around one month. In the United Kingdom, the central bank chooses the maturity range at which it will purchase outright eligible (largely commercial) bills, nowadays 1 to 14 ("Band 1") and 15 to 33 ("Band 2") days, ${ }^{20}$ while the specific maturity is left to the counterparties. In a few of these countries, and to varying degrees, the rates on standing facilities convey information about the longer-term policy stance. This is especially true for the discount window in Italy, given that the tender rate has less visibility than in the other countries in the group (Section 5).

In Switzerland, as the primary focus is on the volume of giro deposits with the central bank, interest rates are of limited significance in conveying policy intentions. ${ }^{21}$ Nevertheless, at times of particular instability in the demand for giro deposits, the central bank has paid closer attention to short-term market rates. Most recently, this has indeed been the case since September 1996 (see below).

These differences in key policy variables across countries can have implications for the extent to which fluctuations in the overnight rate are tolerated. Central banks that define their policy in terms of the overnight rate itself clearly treat it as an operating target. In this case, very high frequency fluctuations may be allowed but only as long as they are perceived as purely technical. Over and above its possible stabilising function, announcing the specific target may be helpful in this respect, since it clarifies the distinction between technical and policy-induced changes. By contrast, in those countries where the key policy rate is a tender rate, and at a longer maturity, the freedom is greater. Here attitudes differ considerably and are not invariant to specific economic and market conditions.

Certain central banks, including those in the United Kingdom, the Netherlands and Belgium, attach comparatively little importance to the overnight rate itself and tend to focus on maturities in the one to three-month range. The others, albeit to different degrees, may be said under normal conditions to follow an overnight rate operating objective. In this case, the overnight rate would typically shadow the policy rate. ${ }^{22}$ In Germany, for instance, this has been described as a situation of "money market equilibrium". The authorities would thus use a variety of signalling strategies, alter liquidity conditions in the market and/or rely on the stabilising properties of reserve requirements to bring the overnight rate into line. This strategy, however, may need to be abandoned at times when a greater degree of variability in the overnight rate is called for, most notably when exchange rate commitments come under pressure (see Graph 2.1 and Annex V for a more detailed treatment).

19 Special Purchase and Resale Agreements (SPRAs) and Sale and Repurchase Agreements (SRAs) at the upper and lower ends, respectively. Since January 1996 changes in the operating band have also been announced through press releases. Until that date the Bank of Canada influenced the overnight rate with a view to achieving a fairly precise target for the three-month Treasury bill rate. For an explanation of the reasons for the change, see Section 5.

20 In the past, the Bank of England also dealt at maturity ranges comprising 33-63 and 64-91 days. Following the departure from the ERM in 1992 and the implementation of the new monetary framework, the Bank of England has started to announce explicitly changes in the official rate at which commercial bill tenders would take place. The central rate plays a similar role in Belgium.

21 The discount rate, however, still retains some role (Section 5).

22 In France the policy rate shadows the overnight rate from below. 
Most countries in the sample steer the overnight rate within a corridor, almost invariably defined by standing facilities at posted rates (see also Table 2.2). ${ }^{23}$ However, in only three cases, Austria, Sweden and Belgium, are the characteristics of the facilities such as to automatically enforce the bounds, viz. generous quantitative limits, no central bank discretion and a one-day maturity of the operations. Elsewhere it is typical for the lower bound to be represented by a subsidised lending facility, which would not necessarily be effective in cases of excess liquidity. In addition, credit at the upper bound may be restricted or granted at maturities longer than overnight (e.g. France).

Table 2.2

\section{Standing facilities ${ }^{1}$}

\begin{tabular}{|c|c|c|c|c|c|c|c|}
\hline & $\begin{array}{c}\text { Market } \\
\text { ceiling }\end{array}$ & $\begin{array}{c}\text { Market } \\
\text { floor }\end{array}$ & $\begin{array}{c}\text { Below } \\
\text { market }\end{array}$ & & $\begin{array}{c}\text { Market } \\
\text { ceiling }\end{array}$ & $\begin{array}{c}\text { Market } \\
\text { floor }\end{array}$ & $\begin{array}{c}\text { Below } \\
\text { market }\end{array}$ \\
\hline $\mathrm{AU}$ & $*$ & $*$ & & $\mathrm{JP}$ & 2 & & $* 2$ \\
\hline $\mathrm{AT}$ & $*$ & $*$ & $*$ & NL & & & $*$ \\
\hline $\mathrm{BE}$ & $*$ & $*$ & $*$ & ES & & & \\
\hline $\mathrm{CA}$ & $* 3$ & 3 & & $\mathrm{SE}$ & $*$ & $*$ & \\
\hline FR & $*$ & & & $\mathrm{CH}$ & $*$ & & 4 \\
\hline $\mathrm{DE}$ & $*$ & 5 & $*$ & UK & 6 & & \\
\hline IT & $*$ & & $*$ & US & & & $*$ \\
\hline
\end{tabular}

${ }^{1}$ For more details, see Section 4. ${ }^{2}$ Discount window credit actually granted with full discretion; the corresponding interest rate has been above market since July 1995. In January 1996 the Bank of Japan announced that it would no longer use discount credit as part of its regular liquidity management operations. ${ }^{3}$ Mainly overdraft loans at Bank rate. In addition, discretionary reversed transactions on occasion operated as quasi-standing facilities. ${ }^{4}$ Deactivated; used for signalling only. ${ }^{5}$ Discretionary issuance of short-term paper on occasion operated as a standing facility. ${ }^{6}$ A number of facilities partly aimed at limiting the rise in the overnight rate.

These arrangements simply reflect the practice of relying heavily on discretionary market operations and various signalling mechanisms to steer the rate within the corridor. As a look at the behaviour of the overnight rate indicates, the bounds hardly ever bite for the market as a whole. This is confirmed by the very low standard deviation of the spread between the overnight and the policy rate: excluding episodes of exchange rate pressure and sharp technical movements at the end of the maintenance periods of reserve requirements, fluctuations so measured have generally not exceeded 15 basis points in recent years (Graph 2.2). The corridors are normally considerably larger, allowing for significant flexibility in the movement of both policy and overnight rates.

Looking across countries, the choice of operating objective is only imperfectly reflected in the money market term structure of the volatilities of spreads vis-à-vis the policy rate. In two of the three countries focusing on longer-term money market rates, the United Kingdom and the Netherlands, the volatilities of the three and one-month rate spreads are considerably lower than the volatility of the overnight spread; this, however, is not so in Belgium (same graph). Similarly, in a majority of countries focusing on the overnight rate as operating objective, the volatility of the corresponding spread is lower than for longer rates; but the United States and Germany are two notable exceptions. ${ }^{24}$

23 In France, the lower bound is the tender rate; in Canada, the limits are set by discretionary operations whose impact on end-of-day liquidity is actually sterilised.

24 The extent to which these results may depend on specific measurement issues is still to be determined. 
Graph 2.2a

\section{Volatility of policy rate spreads 1}
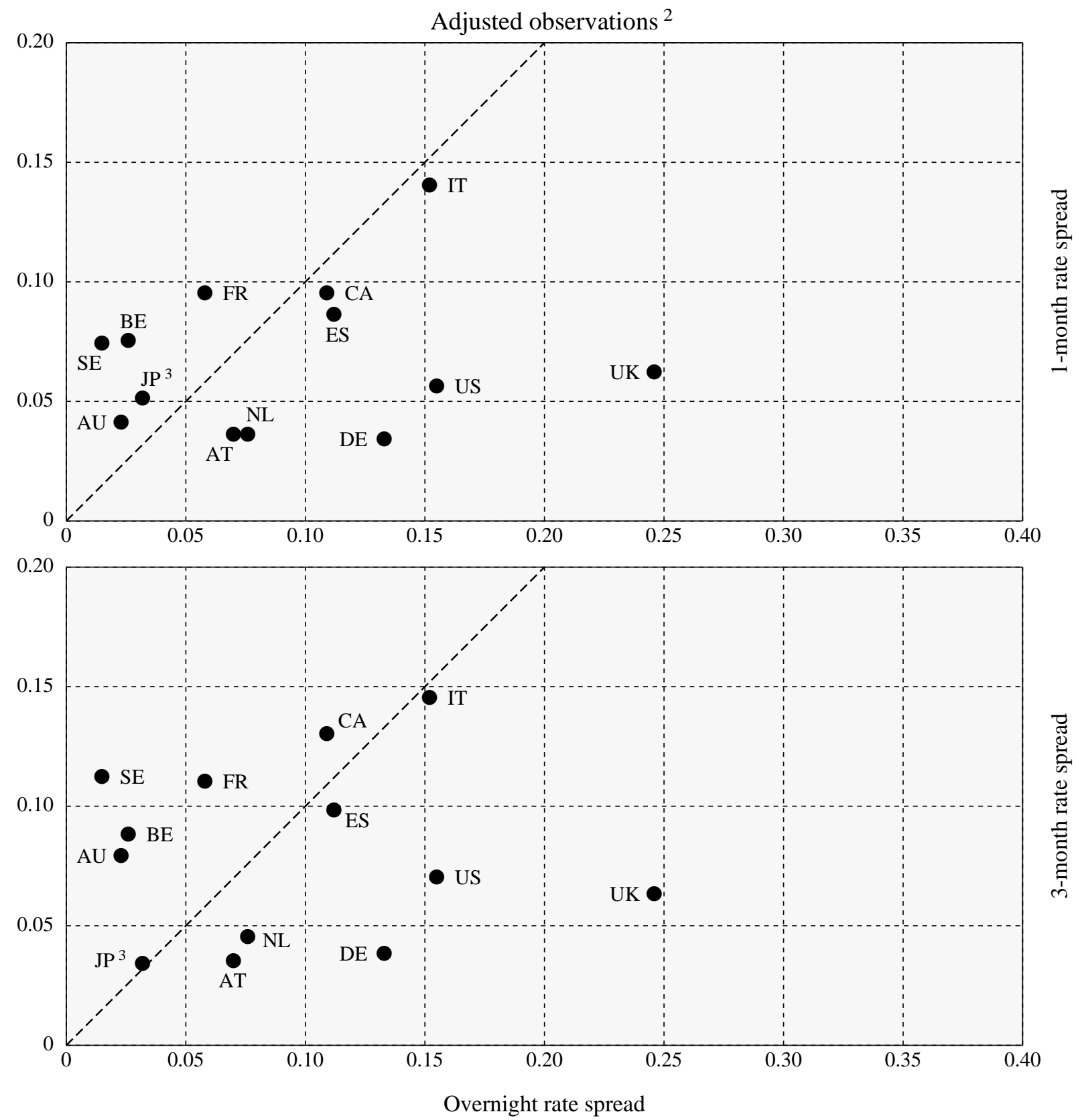

${ }^{1}$ Standard deviation of the daily differential between the chosen money market rate and the policy rate calculated over calendar months, in percentage points; average over January 1994 - September 1996 (for Canada, from 15th April 1994 and for Sweden, from June 1994). $\quad{ }^{2}$ Excluding observations at the end of the maintenance periods and at times of exchange rate pressure, where applicable. $\quad{ }^{3}$ With respect to an estimated overnight rate objective; approximate only. 
Graph 2.2b

\section{Volatility of policy rate spreads ${ }^{1}$}
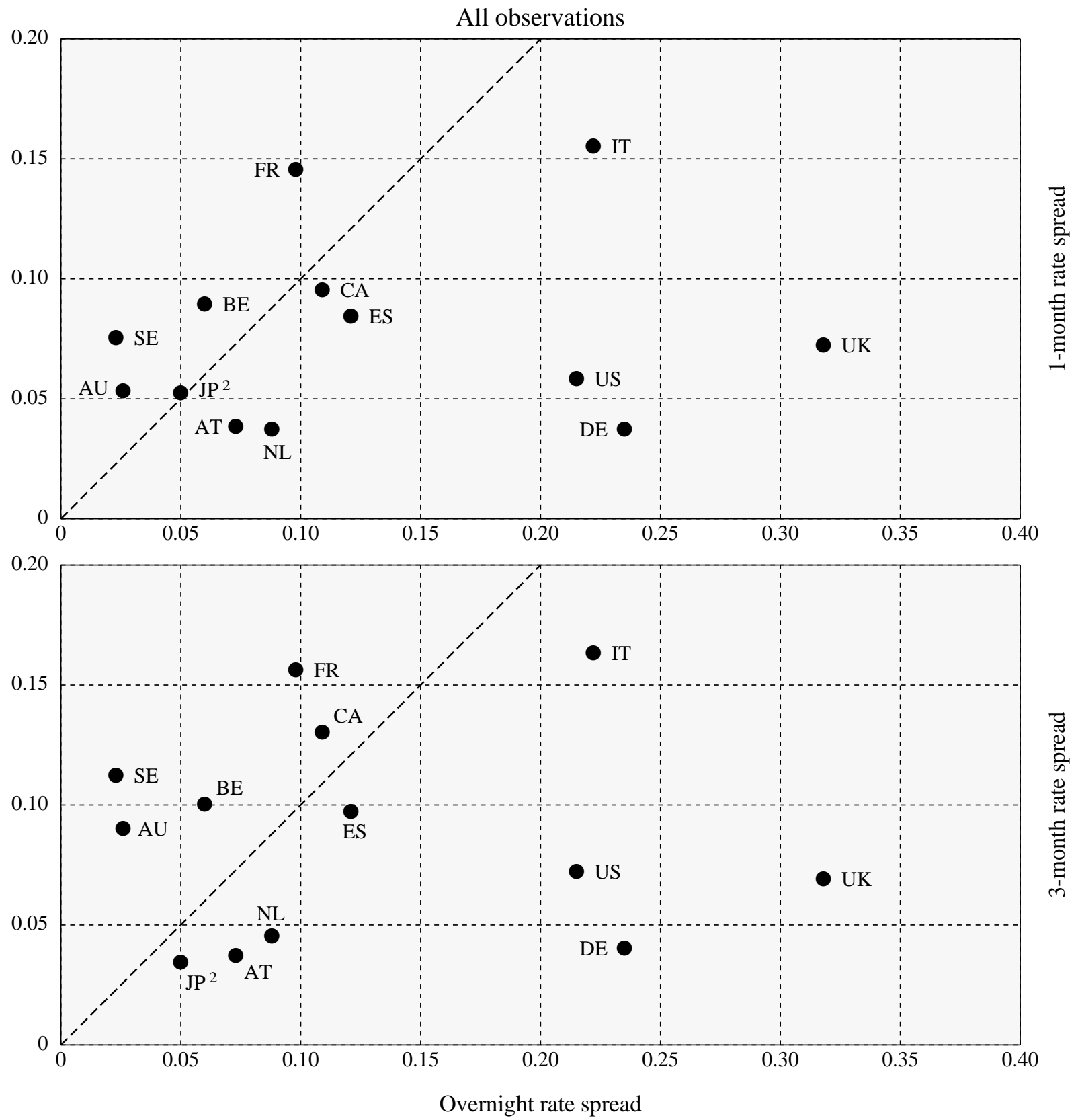

${ }^{1}$ Standard deviation of the daily differential between the chosen money market rate and the policy rate calculated over calendar months, in percentage points; average over January 1994 - September 1996 (for Canada, from 15th April 1994 and for Sweden, from June 1994). $\quad{ }^{2}$ With respect to an estimated overnight rate objective; approximate only.

More generally, in the cross-section of countries there does not at first glance appear to be a positive relationship between volatility spreads at the overnight and longer maturities. A relationship, however, is typically apparent in the time-series within countries (Table 2.3). Taken at face value, these findings would suggest that policies designed to achieve a closer influence on rates at the maturity for the operating objective would normally be associated also with lower volatility at the other benchmark maturities in the money market. 
Table 2.3

Relationship between volatilities in policy rate spreads: simple regressions

\begin{tabular}{|c|c|c|c|c|c|c|c|c|}
\hline & \multicolumn{3}{|c|}{ 1-month on overnight spread } & \multicolumn{3}{|c|}{ 3-month on overnight spread } & \multirow{2}{*}{ Period $^{1}$} & \multirow{2}{*}{$\begin{array}{l}\text { Number of } \\
\text { observations }\end{array}$} \\
\hline & coeff. & $\overline{\mathrm{R}}^{2}$ & SEE & coeff. & $\overline{\mathrm{R}}^{2}$ & SEE & & \\
\hline AU & $\begin{array}{c}1.31 * * * \\
(0.24)\end{array}$ & 0.27 & 0.08 & $\begin{array}{c}1.69 * * * \\
(0.28)\end{array}$ & 0.31 & 0.09 & $90 / 1-96 / 9$ & 78 \\
\hline AT & $\begin{array}{c}0.45 * * * \\
(0.04)\end{array}$ & 0.65 & 0.10 & $\begin{array}{c}0.18 * * * \\
(0.02)\end{array}$ & 0.47 & 0.06 & $89 / 6-96 / 9$ & 87 \\
\hline $\mathrm{BE}$ & $\begin{array}{c}0.57 * * * \\
(0.20)\end{array}$ & 0.11 & 0.09 & $\begin{array}{c}0.39 * * \\
(0.19)\end{array}$ & 0.05 & 0.09 & $91 / 4-96 / 9$ & 57 \\
\hline $\mathrm{CA}$ & $\begin{array}{l}1.01 * \\
(0.51)\end{array}$ & 0.09 & 0.08 & $\begin{array}{l}1.07 * \\
(0.53)\end{array}$ & 0.10 & 0.08 & $94 / 4-96 / 9$ & 30 \\
\hline FR & $\begin{array}{c}0.86 * * * \\
(0.12)\end{array}$ & 0.35 & 0.13 & $\begin{array}{c}0.62 * * * \\
(0.10)\end{array}$ & 0.30 & 0.10 & $88 / 10-96 / 9$ & 86 \\
\hline $\mathrm{DE}$ & $\begin{array}{c}0.22 * * * \\
(0.04)\end{array}$ & 0.19 & 0.05 & $\begin{array}{c}0.16 * * * \\
(0.04)\end{array}$ & 0.12 & 0.04 & $85 / 8-96 / 9$ & 130 \\
\hline IT & $\begin{array}{c}0.42 * * * \\
(0.05)\end{array}$ & 0.54 & 0.16 & $\begin{array}{c}0.37 * * * \\
(0.05)\end{array}$ & 0.48 & 0.16 & $91 / 1-96 / 9$ & 64 \\
\hline $\mathrm{JP}^{2}$ & $\begin{array}{c}0.98 * * * \\
(0.13)\end{array}$ & 0.46 & 0.04 & $\begin{array}{c}0.98 * * * \\
(0.10)\end{array}$ & 0.63 & 0.03 & $91 / 2-96 / 9$ & 62 \\
\hline NL & $\begin{array}{c}0.07 * * * \\
(0.02)\end{array}$ & 0.15 & 0.03 & $\begin{array}{c}0.06 * * * \\
(0.02)\end{array}$ & 0.07 & 0.04 & $87 / 1-96 / 9$ & 113 \\
\hline ES & $\begin{array}{c}0.99 * * * \\
(0.11)\end{array}$ & 0.65 & 0.09 & $\begin{array}{c}0.49 * * * \\
(0.11)\end{array}$ & 0.29 & 0.10 & $91 / 12-96 / 9$ & 48 \\
\hline SE & $\begin{array}{c}0.21 \\
(0.57)\end{array}$ & -0.04 & 0.07 & $\begin{array}{c}0.04 \\
(0.63)\end{array}$ & -0.04 & 0.08 & $94 / 6-96 / 9$ & 26 \\
\hline UK & $\begin{array}{c}0.21 * * * \\
(0.03)\end{array}$ & 0.36 & 0.06 & $\begin{array}{c}0.17 * * * \\
(0.03)\end{array}$ & 0.23 & 0.06 & $87 / 1-96 / 9$ & 100 \\
\hline US & $\begin{array}{c}0.24 * * * \\
(0.06)\end{array}$ & 0.20 & 0.04 & $\begin{array}{c}0.36 \text { *** } \\
(0.07)\end{array}$ & 0.24 & 0.05 & $89 / 8-96 / 9$ & 74 \\
\hline
\end{tabular}

\footnotetext{
${ }^{1}$ Regression of the volatility of the spread between the one-month (or three-month) rate and the policy rate on the volatility of the corresponding spread for the overnight rate; calendar months; excluding episodes of exchange rate pressure and observations at the end of the maintenance period, where applicable. ${ }^{2}$ Based on an estimated overnight rate objective; approximate only.
} 


\subsection{Inbuilt stabilisers versus frequency of operations}

Standing facilities and signalling aside, the volatility otherwise induced in the overnight rate by the variability of the net supply of liquidity through autonomous factors can be reduced in at least two ways: through the buffer property of reserve requirements and through active liquidity management, by means of discretionary liquidity operations. The relative importance of these two factors varies considerably internationally, although the general downward trend in compulsory ratios in recent years (Section 3) has been shifting the balance towards liquidity activism.

In almost half of the countries covered the demand for working balances is the relevant factor affecting the marginal demand for reserves, viz. the United Kingdom, Canada, Australia, Belgium, the Netherlands and Sweden. In these cases, reserve requirements are either not in place or, if they are, do not allow the use of the corresponding balances for settlements purposes, as in the Netherlands and Australia. In Canada and the Netherlands averaging provisions in overdraft facilities are designed to limit the variability in the overnight rate. In Canada banks are penalised only if their average settlement balance is negative over one-month periods; ${ }^{25}$ in the Netherlands a three-month averaging procedure applies to overdrafts granted within bank-specific quotas at slightly below market rates, so that banks aim at holding their accounts with the central bank overdrawn. ${ }^{26}$

In the remaining countries reserve requirements with averaging are in place. The averaging period is generally one month but is considerably shorter in the United States (two weeks) and Spain (ten days); such a short period effectively constrains the banks' ability to absorb fluctuations in liquidity. In all of these systems the reserve requirements are the main binding variable affecting the marginal demand for settlement balances. Nevertheless, in some cases the level is now so low that it can compromise their buffer function. This is the case in France. In the United States the economisation on compulsory reserves through so-called "sweep" accounts risks having a similar effect (Section 3).

These differences in the characteristics of the demand for reserve balances are partly reflected in the frequency of discretionary operations. At one end of the spectrum is the United Kingdom, where even excluding irregular fine-tuning operations the central bank may operate up to three times per day. ${ }^{27}$ In Canada, Australia and Belgium the central bank generally intervenes once a day; in the United States and the Netherlands several times per week. At the other end of the spectrum is Germany, where fine-tuning operations in addition to the regular weekly tender are typically rare. ${ }^{28}$

\subsection{Instruments for market operations}

In principle central banks have a broad array of instruments at their disposal for their market operations (Box 2). However, by far the most popular one used at their discretion is the reversed (repurchase) transaction, which in cash-flow terms is equivalent to a collateralised loan

25 This is described as "zero" reserve requirements with averaging. The rate on overdrafts is set so as to have banks aiming at zero average balances (Section 3).

26 In Australia certain participants can in effect choose the settlement and value date ( $\mathrm{T}$ or $\mathrm{T}+1)$. This in fact amounts to a kind of two-day averaging provision with carry-over (equivalently, to an overnight central bank facility at zero cost). In addition, since mid-1996 remuneration of settlement balances at only 10 basis points below the target rate sets a tight lower bound to fluctuations in the overnight rate.

27 The Bank of Japan also operates up to three times per day: at 9.20 a.m. (signalling operations); at 10.10 a.m. ("housekeeping" liquidity management operations) and, between three or four times a month, later in the day (4.15 p.m.) if there is a need to withdraw liquidity from the system.

28 Certain technical changes have recently reduced the need for these operations, most notably the reduction in float and the introduction of new arrangements regarding government balances. In the past, their frequency had increased considerably for a while following reunification. 
Table 2.4

Discretionary operations: an overview ${ }^{1}$

\begin{tabular}{|c|c|c|c|c|c|c|c|}
\hline & \multicolumn{3}{|c|}{ Reversed transactions } & \multirow{3}{*}{$\begin{array}{c}\text { Outright } \\
\text { transactions }\end{array}$} & \multirow{3}{*}{$\begin{array}{c}\text { Issue of } \\
\text { short-term } \\
\text { paper }\end{array}$} & \multirow{3}{*}{$\begin{array}{c}\text { Interbank } \\
\text { market } \\
\text { transaction } \\
\text { s } \\
\end{array}$} & \multirow{3}{*}{$\begin{array}{c}\text { Transfer of } \\
\text { government } \\
\text { deposits }\end{array}$} \\
\hline & \multicolumn{2}{|c|}{ Domestic currency } & \multirow{2}{*}{$\begin{array}{l}\text { Foreign } \\
\text { currency }\end{array}$} & & & & \\
\hline & inject & withdraw & & & & & \\
\hline $\mathrm{AU}$ & $*$ & $*$ & $* 2$ & $*$ & & & \\
\hline AT & $\otimes$ & $*$ & $* 3$ & & & & \\
\hline $\mathrm{BE}$ & $\otimes$ & & $*$ & $*$ & & $*$ & \\
\hline $\mathrm{CA}$ & $* 4$ & $* 4$ & & 5 & & & $\otimes$ \\
\hline FR & $\otimes$ & & & $*$ & & $*$ & \\
\hline $\mathrm{DE}$ & $\otimes$ & & $*$ & & $* 6$ & & 7 \\
\hline IT & $\otimes$ & $\otimes$ & $*$ & $*$ & & & \\
\hline JP & & $*$ & & $*$ & $*$ & & \\
\hline NL & $\otimes$ & & $* 2$ & & $*$ & $* 8$ & \\
\hline ES & $\otimes$ & $*$ & & & & & \\
\hline SE & $\otimes$ & $\otimes$ & 9 & & & $*$ & \\
\hline $\mathrm{CH}$ & $*$ & $*$ & $*$ & & & & $*$ \\
\hline UK & $*$ & & & $\otimes$ & $* 10$ & & \\
\hline US & $*$ & $*$ & & $*$ & & & \\
\hline
\end{tabular}

Key to symbol: "®" indicates main liquidity management operation with a signalling function.

${ }^{1}$ Other than central bank lending; see Box 2 for an explanation of the taxonomy. ${ }^{2}$ Occasionally. ${ }^{3}$ In principle; not used for the last two years. ${ }^{4}$ Reversed transactions used to signal changes in the operating band but also to enforce its limits; normally sterilised by the end of day via the transfer of government deposits. ${ }^{5}$ None since 1995, in part reflecting the greater focus on the overnight rate at the expense of the three-month Treasury bill rate. ${ }^{6}$ Issue of "liquidity paper", recently only with a view to setting a floor to market rates; issued by the Federal Government upon request by the central bank, which is economically liable for it. ${ }^{7}$ Discontinued in $1994 .{ }^{8}$ On a secured basis only. ${ }^{9}$ Possible, but extremely seldom. ${ }^{10}$ Treasury bill tenders.

(Table 2.4). Repurchase transactions such as repos ${ }^{29}$ are preferred to outright open market operations for several reasons: they do not require a liquid underlying market for securities; ${ }^{30}$ they essentially have only an indirect impact on the price of the securities transferred, via the injection/withdrawal of liquidity and any associated signalling effects; and they break the link between the maturity of the paper and that of the transaction. Indeed, owing to the great flexibility they provide, repurchase operations are sometimes used also in the form of standing facilities. The emergence and subsequent rapid growth of private repo markets in recent years, often encouraged by the central banks themselves, have further spurred the use of these instruments. Generally, reversed transactions against assets denominated in domestic currency account for the bulk of such operations. At the same time, foreign exchange swaps have become somewhat more significant in a number of countries, mainly

29 Depending on the legal and technical characteristics of the instrument, a distinction is often made between repos and buy-sellback transactions. The terms will be used interchangeably in what follows.

30 On the other hand, they help to increase the liquidity of the underlying market. 
owing to the combination of a sharper focus on exchange rate commitments and greater capital mobility. Foreign exchange swaps have traditionally been the main policy instrument in Switzerland.

The only two countries where reversed transactions are not the primary tool for adjusting the marginal supply of liquidity are Canada and the United Kingdom. ${ }^{31}$ The Bank of Canada effects daily liquidity adjustments through the redeposit/drawdown facility, by transferring government deposits between its balance sheet and that of clearing banks. In the United Kingdom outright purchases of eligible bills are still the pivotal instrument; the very large outstanding market in the commercial bills has rendered this possible. Since 1994, however, the central bank has made increasing use of repos, a development which is set to continue following the opening of the private repo market in January $1996 .{ }^{32}$

Outright transactions in the secondary market do play some role in a few other countries. In Italy, France and Belgium, where the underlying debt markets are comparatively large, they are sometimes used for fine-tuning or as a structural source of central bank money (France). In the United States, periodic purchases and, infrequently, sales of government securities are used as "permanent" additions/withdrawals of reserves. In Japan, the central bank regularly purchases government bonds in fulfilment of its legal obligation to supply base money to support economic growth.

In a few cases central banks may transact in the primary market by issuing their own or government paper on its behalf. The Bundesbank has sometimes issued "liquidity paper" with a maturity of between one and three days at a pre-announced rate as a means of setting a floor to interest rates. ${ }^{33}$ Since 1994 the Netherlands Bank has issued six-month certificates in order partly to release the reserve requirement from its task of inducing a net shortage of liquidity. A similar function is performed by the weekly Treasury bill tenders in the United Kingdom. When withdrawals of liquidity are necessary, the Bank of Japan also issues its own bills, of a maturity between one and five weeks on a tender basis, as a complement to reversed sales of financing bills.

\section{The demand for bank reserves}

It is now worth examining the demand for bank reserves in more detail. What follows looks at the relationship between the demand for working balances and payment and settlement system arrangements and at the functions and characteristics of reserve requirements.

\subsection{Working balances}

In virtually all countries, banks target small settlement balances whose amounts appear to be highly insensitive to movements in the overnight rate. The amounts held are largely dictated by the technical and institutional characteristics of payment and settlement arrangements, including the central bank's attitude to the provision of end-of-day marginal financing. These are generally such as to limit the need for precautionary balances (Table 3.1).

31 For present purposes, the Netherlands Bank's special advances (collateralised loans) can be viewed as reversed transactions.

32 Quantitatively, repos are now even more important. Moreover, the practice of announcing changes in "official" rates has partly deprived eligible bill tenders of their independent policy-setting role.

33 For some time, it also issued similar paper at longer maturities (Annex V). 
Table 3.1

Institutional arrangements and settlement balances

\begin{tabular}{|c|c|c|c|c|c|c|c|c|c|c|c|c|c|c|}
\hline & $\mathbf{A U}$ & AT & BE & $\mathbf{C A}$ & FR & DE & IT & $\mathbf{J P}$ & NL & ES & SE & $\mathbf{C H}$ & UK & US \\
\hline Settlement requirement ${ }^{1}$ & * & & & $*$ & 2 & & & & & & & & & \\
\hline Main system & $\mathrm{N}$ & $G^{3}$ & RTGS $^{4}$ & $\mathrm{~N}$ & $\mathrm{~N}$ & N/RTGS & $\mathrm{N}$ & $\mathrm{N}$ & $\mathrm{N}$ & G & RTGS & RTGS & RTGS & RTGS \\
\hline - pre-settlement round ${ }^{5}$ & $*$ & & $*$ & & $*$ & $*$ & $*$ & $*$ & & $*$ & & $*$ & $*$ & $*$ \\
\hline - intraday monitoring 6 & $*$ & $*$ & $*$ & & 7 & & $*$ & $*$ & $*$ & * & $*$ & $*$ & $*$ & $*$ \\
\hline $\begin{array}{l}\text { Marginal } \\
\text { accommodation }\end{array}$ & $\begin{array}{l}\text { Redisc- } \\
\text { ount }\end{array}$ & Lombard & Advance & $\begin{array}{l}\text { Over- } \\
\text { draft }\end{array}$ & $\begin{array}{l}\text { Over- } \\
\text { draft }\end{array}$ & Lombard & $\begin{array}{l}\text { Fixed- } \\
\text { term }\end{array}$ & Discount & $\begin{array}{l}\text { Quota } \\
\text { scheme }\end{array}$ & Loan & $\begin{array}{l}\text { Lending } \\
\text { facility }\end{array}$ & Lombard & Overdraft & $\begin{array}{l}\text { Discount/ } \\
\text { overdraft }\end{array}$ \\
\hline - overdraft ${ }^{8}$ & & & & & & & advance & & & & & & 10 & 10 \\
\hline - pre-known terms & $*$ & $*$ & * & * & $*$ & $*$ & $*$ & * & * & & * & $*$ & & $*$ \\
\hline - discretion & & $*$ & & & $* 11$ & $* 12$ & $* 13$ & $*$ & & $*$ & & & * & $* 14$ \\
\hline • suasion & & $*$ & & & $* 11$ & $* 12$ & $* 13$ & $*$ & & $*$ & & & $*$ & $* 14$ \\
\hline - maturity & $\leq 90 \mathrm{~d}$ & $\mathrm{O} / \mathrm{N}^{15}$ & $\mathrm{O} / \mathrm{N}$ & $\mathrm{O} / \mathrm{N}$ & $\mathrm{O} / \mathrm{N}$ & variable $^{12}$ & $1-32 d^{16}$ & variable & indet. ${ }^{17}$ & $\mathrm{O} / \mathrm{N}$ & $\mathrm{O} / \mathrm{N}$ & $\geq \mathrm{O} / \mathrm{N}$ & $\mathrm{O} / \mathrm{N}$ & $\mathrm{O} / \mathrm{N}$ \\
\hline - interest rate & $\begin{array}{c}\text { market + } \\
0.75 \%\end{array}$ & Lombard & $\begin{array}{l}\text { central + } \\
1.25 \%{ }^{19}\end{array}$ & $\begin{array}{l}\text { Bank } \\
\text { rate }^{20}\end{array}$ & $\begin{array}{l}5 \text { to } 10- \\
\text { day } \\
+2 \% 9\end{array}$ & Lombard & $\begin{array}{c}\text { Fixed- } \\
\text { term } \\
\text { advances }^{2} \\
1\end{array}$ & $\begin{array}{c}\text { Disc- } \\
\text { ount }^{22}\end{array}$ & $\begin{array}{c}\text { Tender - } \\
0.20- \\
0.30 \%\end{array}$ & penal & $\begin{array}{l}\text { Lending } \\
\text { facility }^{23}\end{array}$ & $\begin{array}{l}\text { Lom- } \\
\text { bard }^{24}\end{array}$ & penal $^{25}$ & $\begin{array}{l}\mathrm{O} / \mathrm{N}+ \\
4 \%^{26}\end{array}$ \\
\hline • collateral & $*$ & * & $*$ & $*$ & $* 9$ & $*$ & * & $*$ & $*$ & $*$ & & $*$ & $*$ & $*$ \\
\hline $\begin{array}{l}\text { - use } \\
\text { Remuneration balances }\end{array}$ & $\begin{array}{l}\text { very rare } \\
\quad * 27\end{array}$ & very rare & marginal & active & rare & rare & $\begin{array}{l}\text { common } \\
\quad * 28\end{array}$ & very rare & active & rare & limited & rare & occasional & infrequent \\
\hline
\end{tabular}

Key to symbols: $\mathrm{N}=$ discrete-time net settlement; $\mathrm{G}=$ discrete-time gross settlement; RTGS = real-time gross settlement.

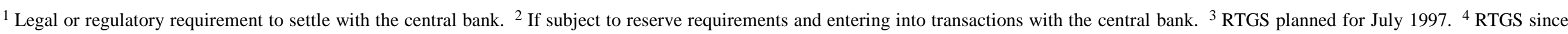

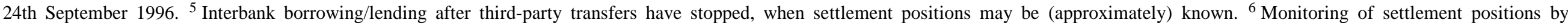

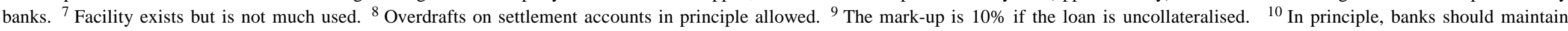

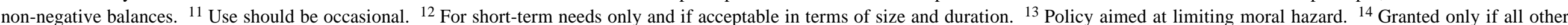

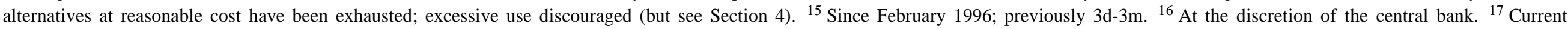

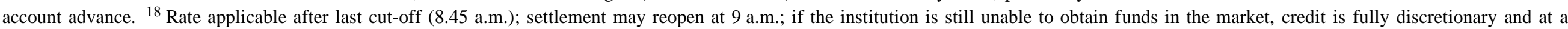

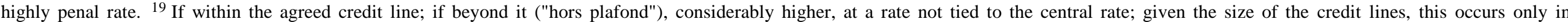

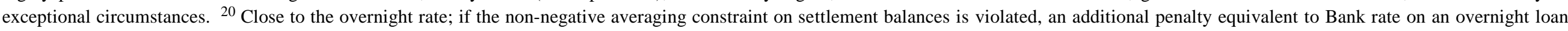

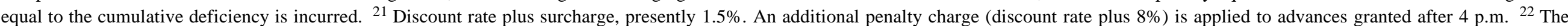

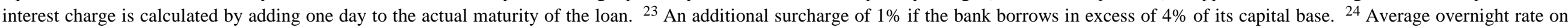

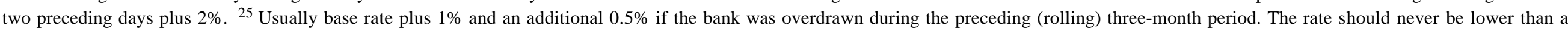

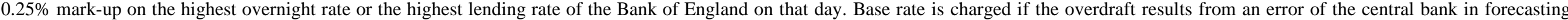
liquidity. ${ }^{26}$ If unintended overdraft; discount rate otherwise. ${ }^{27}$ Overnight target rate minus $0.10 \%$. ${ }^{28}$ Excess reserves remunerated at $0.5 \%$. 
At least three factors help to reduce the need for precautionary balances. First, settlement procedures are typically designed to allow banks to borrow and lend among themselves towards the end of the day after settlement positions are known or can be estimated with a comparatively small margin of error because other markets have closed and third parties are no longer allowed to transact ("pre-settlement rounds"). As long as this interbank market among settlement participants works sufficiently smoothly, the institutions can be confident of obtaining funds at the going market rate. Difficulties can still arise, especially if a bank builds up a large net debit position, which could put it at a competitive disadvantage in the clearing or even exhaust its available credit lines. Nevertheless, these problems can be alleviated by active monitoring and management of the cash positions during the day. Second, the expectation of being able to finance imbalances at a non-penal rate is generally reinforced by central bank behaviour. As a rule, central banks try to ensure that sufficient funds are available in the system so that participants do not need to turn to them for assistance. ${ }^{34}$ Indeed, in the several cases where end-of-day assistance is granted at posted rates, it is precisely this attitude to liquidity provision which ensures that the cost of such assistance retains a penal character. Finally, this modus operandi, buttressed at times by moral suasion discouraging banks from turning to the central bank, in turn encourages the development of an active and efficient interbank market, which over time reduces the need for central bank intervention at the end of the day.

Two major exceptions to this general picture are the Netherlands and Canada. In the Netherlands, since end-of-day central bank overdrafts are granted at (just) below market rates within quotas, banks would willingly attempt, and be allowed, to overdraw their accounts. ${ }^{35}$ In Canada the central bank relies on uncertainty in end-of-day positions by transferring government deposits between its books and those of the clearers after the interbank market has closed, so that clearers with deficient reserves would need to draw on central bank overdrafts. ${ }^{36}$ In conjunction with the averaging provision on the settlement balance requirement, this element of uncertainty makes the settlement balance target responsive to changes in the overnight rate induced by adjustments in the supply of reserves via the redeposit/drawdown scheme. Supplying, say, a somewhat larger amount than that targeted by banks is expected to put downward pressure on the overnight rate. It is still an open question, however, how much of the downward pressure occurs through a mechanical liquidity effect or, more fundamentally, through the signal conveyed regarding policy intentions (Section 5 and Annex V). ${ }^{37}$

Several pieces of evidence support the view that the demand for settlement balances is typically extremely insensitive to movements in the overnight rate. These include spikes observed in interest rates at the end of maintenance period, when the demand for working balances becomes binding (see below); the efforts devoted in several of the countries without binding reserve requirements to finding out the level of "target" balances of banks, not least by asking them directly (Section 4); the greater liquidity management activism of the central banks in these countries; and, perhaps most simply, the fact that even on a daily basis similar amounts of settlement balances are

34 This is so unless they want to give a signal regarding interest rates (Section 5).

35 However, the fact that the interest rate remains below market rates indicates that the facility does not represent, on average, the marginal source of reserves equilibrating the market, which is provided by special advances.

36 The central bank transfers the government deposits on the morning of the following day $(\mathrm{T}+1)$ before markets open and information about exact clearing positions becomes known. Settlement then takes place retroactively, with value date $\mathrm{T}$.

37 The distinction here is between a movement along a well-behaved interest-elastic demand curve and a shift in, or choice of a specific point on, that curve (see Graphs 1.1 and 1.2). Note that the overnight rate at $\mathrm{T}$ has already been determined once the central bank acts. At best, this rate can be affected by the expectation of the central bank supply of liquidity for day T. Similarly, unless what the central bank does for date $\mathrm{T}$ conveys information about what it intends to do for date $\mathrm{T}+1$, the beginning-of-day balances at $\mathrm{T}+1$ do not help to determine expected supply for that date. Conditions in the overnight market for funding during day $\mathrm{T}+1$ might be affected, but not the precautionary end-of-day positions. 
compatible with very different overnight rates. ${ }^{38}$ If this puts a premium on signalling mechanisms, it also raises questions about how signalling can actually "work" (Section 5).

\subsection{Reserve requirements}

Reserve requirements can perform at least four functions (Table 3.2). First, they can help to stabilise the overnight rate in the face of changes in liquidity conditions ("buffer function"). Second, they represent a source of demand for central bank reserves, thus contributing to offsetting the supply of liquidity generated through autonomous factors ("liquidity management function"). Third, they can be used as a means of controlling monetary aggregates ("monetary control function"). Finally, they can be regarded as a source of revenue for the central bank ("income or tax function"). Clearly, the same set of requirements would in practice perform more than one function at the same time, but its characteristics would largely depend on the primary objective of the authorities.

Table 3.2

Functions of reserve requirements ${ }^{1}$

\begin{tabular}{|l|c|c|c|c|}
\hline \multirow{2}{*}{ AU } & $\begin{array}{c}\text { Interest rate } \\
\text { buffer }\end{array}$ & $\begin{array}{c}\text { Liquidity } \\
\text { management }\end{array}$ & $\begin{array}{c}\text { Monetary } \\
\text { control }\end{array}$ & $\begin{array}{c}\text { Seigniorage } \\
\text { income }^{3}\end{array}$ \\
\cline { 2 - 5 } AT & $*$ & $*$ & $*$ & $*$ \\
FR & $*$ & $*$ & $*$ & $*$ \\
DE & $*$ & $*$ & & $*$ \\
IT & $*$ & $*$ & & $*$ \\
JP & $*$ & & & $*$ \\
ES & $*$ & & & $*$ \\
CH & $*$ & & & $*$ \\
UK & $*$ & & & $*$ \\
US & $*$ & & & $*$ \\
\hline
\end{tabular}

${ }^{1}$ No reserve requirements are in place in Belgium and Sweden. In Canada banks must maintain a non-negative balance before overdrafts on their account with the central bank only on average during one-month periods. ${ }^{2}$ Defined here as a situation in which the requirement is adjusted to absorb the liquidity created by autonomous factors or to create or enlarge a liquidity shortage. ${ }^{3}$ Defined as a situation in which remuneration is considerably below market rates. ${ }^{4}$ Quantity-oriented procedures until May 1990. ${ }^{5}$ Arguably used for this purpose during the period of non-borrowed reserves targeting (October 1979-October 1982).

Few countries retain reserve requirements mainly or exclusively with the objective of raising revenue. This is the sole aim in the United Kingdom (the Cash Ratio Deposits) and in

38 The very language used by those in charge of implementing policy reinforces this conclusion. They normally talk of meeting the required "liquidity shortage/surplus" without mentioning interest rates as a factor determining it. Hence the distinction is made between "technical" liquidity operations, designed to "balance the market", and "monetary policy" operations, designed to alter the policy stance. 


\section{Box 3 \\ Reserve requirement accounting}

Two important elements defining reserve requirements are the calculation and the maintenance (or "holding") period. The calculation period refers to the period (day(s)) taken into account for the calculation of the base to which the compulsory ratio applies. The maintenance period is the period for which the corresponding required reserves must be held.

Depending on the degree of overlap between the calculation and maintenance periods, reserve requirements can be classified into three groups, illustrated in the diagrams below.*

Lagged: $\quad$ the calculation period precedes the maintenance period $\left(t_{2}^{c}<t_{1}^{m}\right)$

Semi-lagged: $\quad$ the calculation period partly overlaps with the maintenance period $\left(t_{2}^{c}>t_{1}^{m}\right)$

Contemporaneous: the end of the calculation and maintenance periods coincide $\left(t_{2}^{c}=t_{1}^{m}\right)$
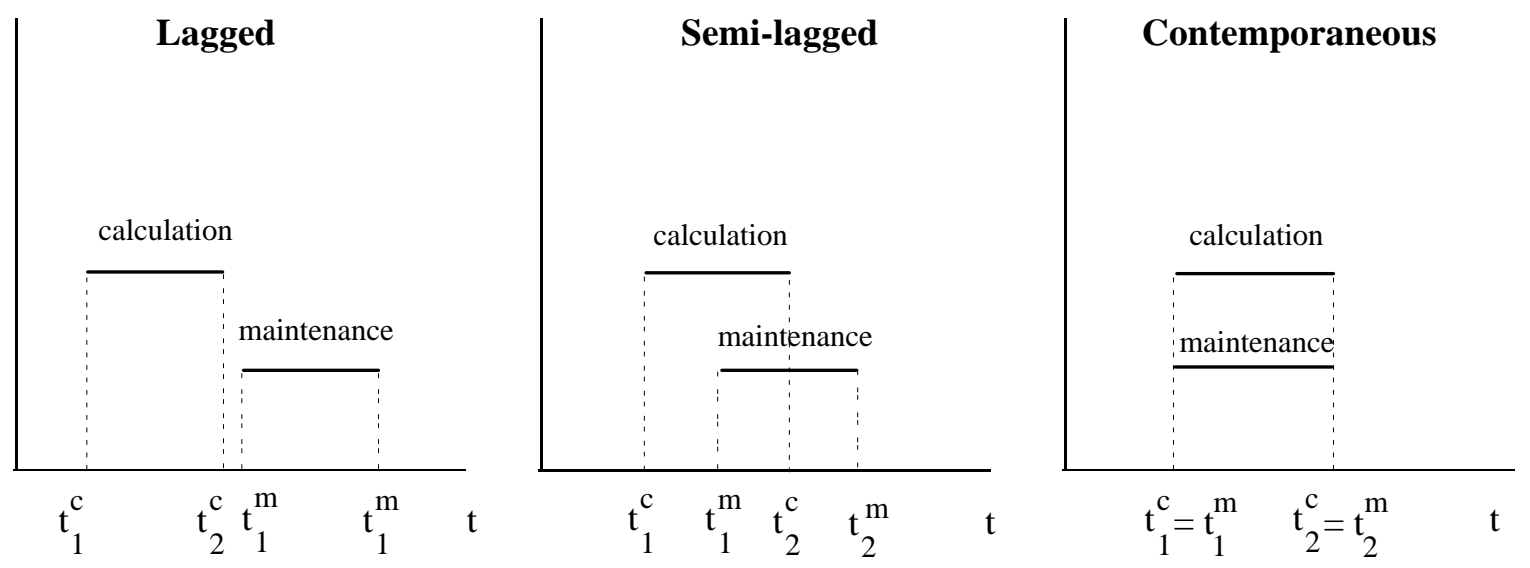

In practice, wholly contemporaneous reserve requirements are not possible because there is typically a lag of at least a couple of days, and sometimes considerably longer, before information on the items making up the base of the requirements (generally deposits) becomes available.

The main significance of the different types is that unless the requirements are lagged, the exact amount of the reserve requirement is unknown at the beginning of the maintenance period and needs to be forecast, both by banks and by the central bank. This adds a further element of uncertainty in liquidity management. With fully contemporaneous reserve requirements, uncertainty prevails until the last day of the holding period. The lag in the collection of the statistics means that between two days and one week may need to be added to the end of the calculation period to identify the day on which residual uncertainty is resolved.

* In the diagram the calculation and maintenance periods are drawn of equal length but this need not be the case. In particular, calculation periods are often defined as averages of liabilities outstanding on a few days and sometimes even as the amounts outstanding on a single day (see Table 3.4). 
Australia (Special Deposits). In these cases, the required balances cannot be used for payments ${ }^{39}$ and the holding period lags the calculation period (Box 3). In general, however, the marked international trend towards a reduction in reserve requirements over the last decade (Table 3.3) has reflected precisely a wish to reduce the tax aspect of the requirements with a view to lightening the burden on institutions and eliminating competitive distortions, both between types of domestic institution and, increasingly, across national borders. In fact, in the United Kingdom the ratio is kept to the minimum necessary to make up for the fact that seigniorage arising from the note issue is paid automatically to the Treasury; the central bank makes every effort to minimise the burden on the monetary sector. Generally, rough estimates of the implicit tax associated with the requirements indicate that this is typically quite low nowadays, well below $1 / 4 \%$ of GDP. Where the level of the requirements is comparatively high, as in Italy, remuneration partly offsets the cost.

Table 3.3

Reserve requirements: size and seigniorage income

\begin{tabular}{|c|c|c|c|c|c|c|}
\hline & \multicolumn{2}{|c|}{ Range of ratios } & \multicolumn{2}{|c|}{ Size $^{1}$} & \multicolumn{2}{|c|}{ Seigniorage income ${ }^{2}$} \\
\hline & $1990^{3}$ & $1996^{4}$ & $1990^{3}$ & $1996^{4}$ & $1990^{3}$ & $1996^{4}$ \\
\hline & \multicolumn{2}{|c|}{ in percentage points } & \multicolumn{4}{|c|}{ as a percentage of GDP } \\
\hline $\mathrm{AU}$ & 1.0 & 1.0 & 0.69 & 0.79 & 0.04 & 0.04 \\
\hline AT & $4.5-9.0$ & $3.0-5.0$ & 4.19 & 2.34 & 0.04 & 0.01 \\
\hline $\mathrm{BE}$ & - & - & - & - & - & - \\
\hline $\mathrm{CA}$ & $\ldots$ & - & $\ldots$ & - & $\ldots$ & - \\
\hline FR & $0.5-5.5$ & $0.5-1.0$ & 0.90 & 0.26 & 0.09 & 0.01 \\
\hline $\mathrm{DE}$ & $4.15-12.1^{5}$ & $1.5-2.0$ & 2.58 & 1.08 & $0.25^{5}$ & 0.04 \\
\hline IT & $22.5-25.0^{6}$ & $15.0^{6}$ & 9.58 & 3.74 & 0.73 & 0.12 \\
\hline JP & $0.125-2.5$ & $0.05-1.3$ & 1.13 & 0.68 & 0.09 & 0.00 \\
\hline NL & variable & variable & 1.28 & 1.11 & 0.00 & 0.00 \\
\hline ES & $5.0^{7}$ & 2.0 & 2.80 & 1.29 & 0.50 & 0.10 \\
\hline SE & - & - & - & - & - & - \\
\hline $\mathrm{CH}$ & 2.5 & 2.5 & 0.71 & 0.76 & 0.06 & 0.02 \\
\hline UK & 0.45 & 0.35 & 0.31 & 0.24 & 0.04 & 0.01 \\
\hline US & $3.0-12.0$ & $3.0-10.0$ & 0.55 & 0.22 & 0.04 & 0.01 \\
\hline
\end{tabular}

${ }^{1}$ Vault cash excluded, if possible. ${ }^{2}$ Three-month interest rates applied. ${ }^{3}$ End of period. ${ }^{4}$ Mid-period. ${ }^{5} 1991$. ${ }^{6}$ Applied to the change in eligible liabilities. ${ }^{7}$ In March 1990, 17.0-19.0.

In line with the focus on interest rates as operating targets, no country now uses reserve requirements as a means of controlling monetary aggregates from the supply side. This issue has been most relevant in the United States, at the time of non-borrowed reserves targeting (October 1979-October 1982), and Spain, where quantity-oriented operating procedures were in place until 1990. In these two countries, reserve requirements still retain features consistent with such a

39 Since the recent introduction of RTGS in the United Kingdom the holdings can be used for intraday settlements, but the requirement must still be fully met at the end of the day. 
Table 3.4

Main features of reserve requirements ${ }^{1}$

\begin{tabular}{|c|c|c|c|c|c|c|c|c|c|c|c|c|c|}
\hline & $\mathbf{A U}$ & AT & FR & DE & IT & $\mathbf{J P}$ & NL & $\mathbf{E S}$ & $\mathbf{C H}$ & $\mathbf{U K}^{2}$ & US & $\mathbf{C A}^{3}$ & $\mathbf{N L}^{4}$ \\
\hline Use for settlements & & $*$ & $*$ & $*$ & $* 5$ & * & & $*$ & $*$ & & $*$ & $*$ & $*$ \\
\hline Averaging & & $*$ & $*$ & $*$ & $*$ & $*$ & & $*$ & $*$ & & $*$ & $*$ & $*$ \\
\hline Carry-over & & & $* 6$ & & & & & & & & $* 7$ & & \\
\hline Type & lagged & $\begin{array}{l}\text { semi- } \\
\text { lagged }\end{array}$ & $\begin{array}{l}\text { semi- } \\
\text { lagged }\end{array}$ & $\begin{array}{l}\text { semi- } \\
\text { lagged }\end{array}$ & lagged & $\begin{array}{l}\text { semi- } \\
\text { lagged }\end{array}$ & lagged & $\begin{array}{c}\text { almost } \\
\text { contemp. }\end{array}$ & lagged & lagged & $\begin{array}{c}\text { almost } \\
\text { contemp. }\end{array}$ & - & lagged \\
\hline $\begin{array}{l}\text { Maintenance period } \\
\text { - end (day) }\end{array}$ & $\begin{array}{c}1 \mathrm{~m} \\
\text { end-m }\end{array}$ & $\begin{array}{c}1 \mathrm{~m} \\
\text { end-m }\end{array}$ & $\begin{array}{c}1 \mathrm{~m} \\
15 \mathrm{th}\end{array}$ & $\begin{array}{c}1 \mathrm{~m} \\
\text { end-m }\end{array}$ & $\begin{array}{c}1 \mathrm{~m} \\
14 \mathrm{th}\end{array}$ & $\begin{array}{c}1 \mathrm{~m} \\
15 \mathrm{th}\end{array}$ & $\begin{array}{c}\text { 7-10d } \\
\text { variable }\end{array}$ & $\begin{array}{c}10 \mathrm{~d}^{9} \\
\text { variable }\end{array}$ & $\begin{array}{c}1 \mathrm{~m} \\
19 \text { th }\end{array}$ & $\begin{array}{c}6 \mathrm{~m} \\
\text { end-m }\end{array}$ & $\begin{array}{c}2 \mathrm{w} \\
\text { Wed. }\end{array}$ & $\begin{array}{c}\text { 4-5w } \\
\text { 3rd Wed. }\end{array}$ & $\begin{array}{c}3 \mathrm{~m} \\
3 \mathrm{rd} \text { Th. }\end{array}$ \\
\hline $\begin{array}{l}\text { Calculation period } \\
\text { - end (day) }\end{array}$ & $\operatorname{lm}_{\text {end- }} \mathrm{m}^{12}$ & $\underset{15 \mathrm{th}^{13}}{1 \mathrm{~m}}$ & $\begin{array}{c}1 \mathrm{~d} \\
\text { end-m }\end{array}$ & $\begin{array}{c}1 \mathrm{~m} \\
15 \mathrm{th}^{14}\end{array}$ & $\underset{\text { end- } \mathrm{m}^{12}}{1 \mathrm{~m}}$ & $\begin{array}{c}1 \mathrm{~m} \\
\text { end-m }\end{array}$ & $\begin{array}{c}3 \mathrm{~m} \\
\text { end- } \mathrm{m}^{15}\end{array}$ & $\begin{array}{c}10 \mathrm{~d}^{9} \\
\text { variable }\end{array}$ & $\begin{array}{c}3 \mathrm{~m} \\
\text { end-m }\end{array}$ & $\begin{array}{c}6 \mathrm{~m}^{10} \\
\text { end- } \mathrm{m}^{10}\end{array}$ & $\begin{array}{c}2 \mathrm{w} \\
\text { Monday }\end{array}$ & - & $\begin{array}{l}3 \mathrm{~m}^{11} \\
\text { end-m }\end{array}$ \\
\hline $\operatorname{Lag}^{16}$ & $1 \mathrm{~m}$ & $15 \mathrm{~d}$ & $15 \mathrm{~d}$ & $15 \mathrm{~d}$ & $45 \mathrm{~d}$ & $15 \mathrm{~d}$ & variable & $2 d$ & $50 \mathrm{~d}$ & $\approx 6 \mathrm{~m}$ & $2 d$ & - & $4 \mathrm{~m}$ \\
\hline Vault cash & & & $*$ & & & & & & $* 17$ & & $*$ & - & - \\
\hline - restricted & - & & & - & - & - & - & - & & - & & - & - \\
\hline Remuneration & $* 18$ & & & & $* 19$ & & $* 20$ & & $* 21$ & & & - & - \\
\hline Penalties & & $* 22$ & $* 23$ & $* 24$ & $* 25$ & $* 26$ & - & $* 27$ & $* 28$ & $* 29$ & $* 30$ & $* 31$ & - \\
\hline Range of ratios $(\%)^{32}$ & 1.0 & $3.0-5.0$ & $0.5-1.0$ & $1.5-2.0$ & $15.0^{33}$ & $0.05-1.3$ & variable & 2.0 & 2.5 & 0.35 & $3.0-10.0$ & 0.0 & variable \\
\hline Last change & mid-1980s & Sept. 95 & Jan. 94 & Aug. 95 & May 94 & Oct. 91 & Dec. $96^{34}$ & Nov. $93^{31}$ & Jan. 88 & Jan. 92 & Dec. 95 & July 94 & - \\
\hline
\end{tabular}

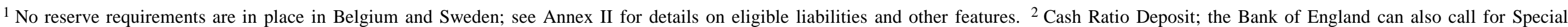

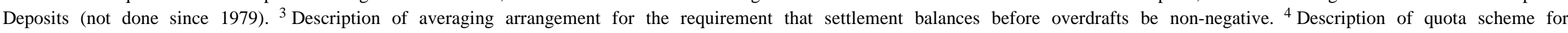

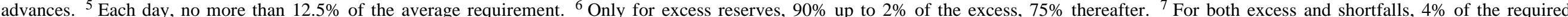

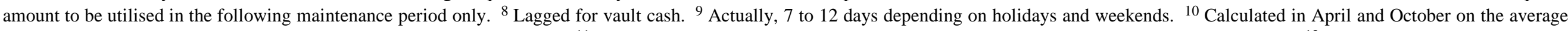

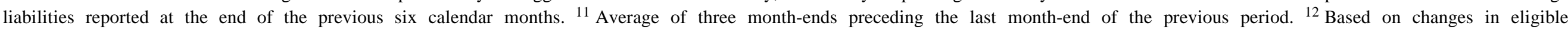

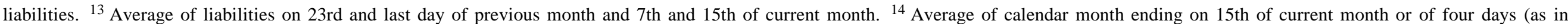

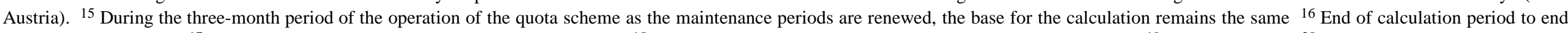

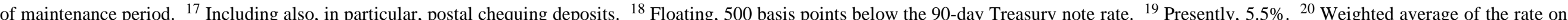

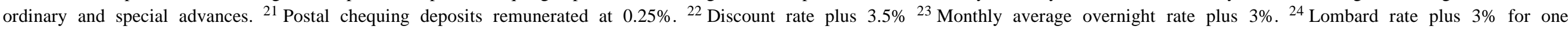

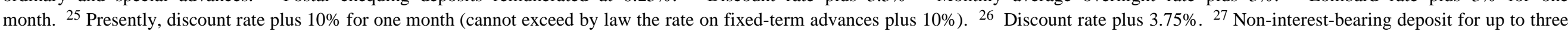

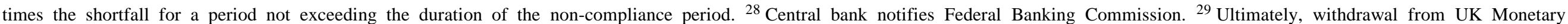
Sector. ${ }^{30}$ Discount rate plus $2 \%$. ${ }^{31}$ Bank rate (overnight). ${ }^{32}$ Non-zero ones only. ${ }^{33}$ Applied to the change in eligible liabilities. ${ }^{34}$ The ratio changes every maintenance period. 
quantity-oriented approach: comparatively short maintenance periods (two weeks and ten days respectively), ${ }^{40}$ almost no lag between the end of the calculation and maintenance periods (almost "contemporaneous" reserve accounting) and, broadly speaking, a definition of eligible liabilities which closely matches that of the previously targeted aggregates (M1 and ALP respectively) (Table 3.4). In Switzerland the traditional operating target, giro deposits, is in fact only one of the assets eligible for the fulfilment of the reserve requirement, actually a liquidity requirement originally imposed for prudential reasons. Recently, an unexpected shift away from reservable postal chequing accounts into giro deposits has tended to result in a temporarily tighter monetary stance than intended. ${ }^{41}$ As a result, the central bank has been focusing more closely on interest rates.

The only country where reserve requirements are now intended to perform primarily, in fact exclusively, a liquidity management function is the Netherlands. In order to maximise the flexibility of the requirements in this role, the authorities flexibly adjust the level of the ratio and the length of the maintenance period in order to meet the changing profile of the autonomous creation of liquidity, in particular that arising from changes in the Treasury balance. The amount of liquidity thus absorbed has to ensure that the system is in a net liquidity shortage, consistently with the operation of the quota scheme and special advances, exclusively liquidity-supplying instruments (Section 4). Recently, reserve requirements have been giving way to more market-oriented means of draining liquidity, through issues of central bank certificates. This trend towards a reduced role of requirements as liquidity-draining instruments has been common to several countries, including Italy and Spain.

Graph 3.1

\section{Volatility of the overnight and three-month interest rate in the United States}

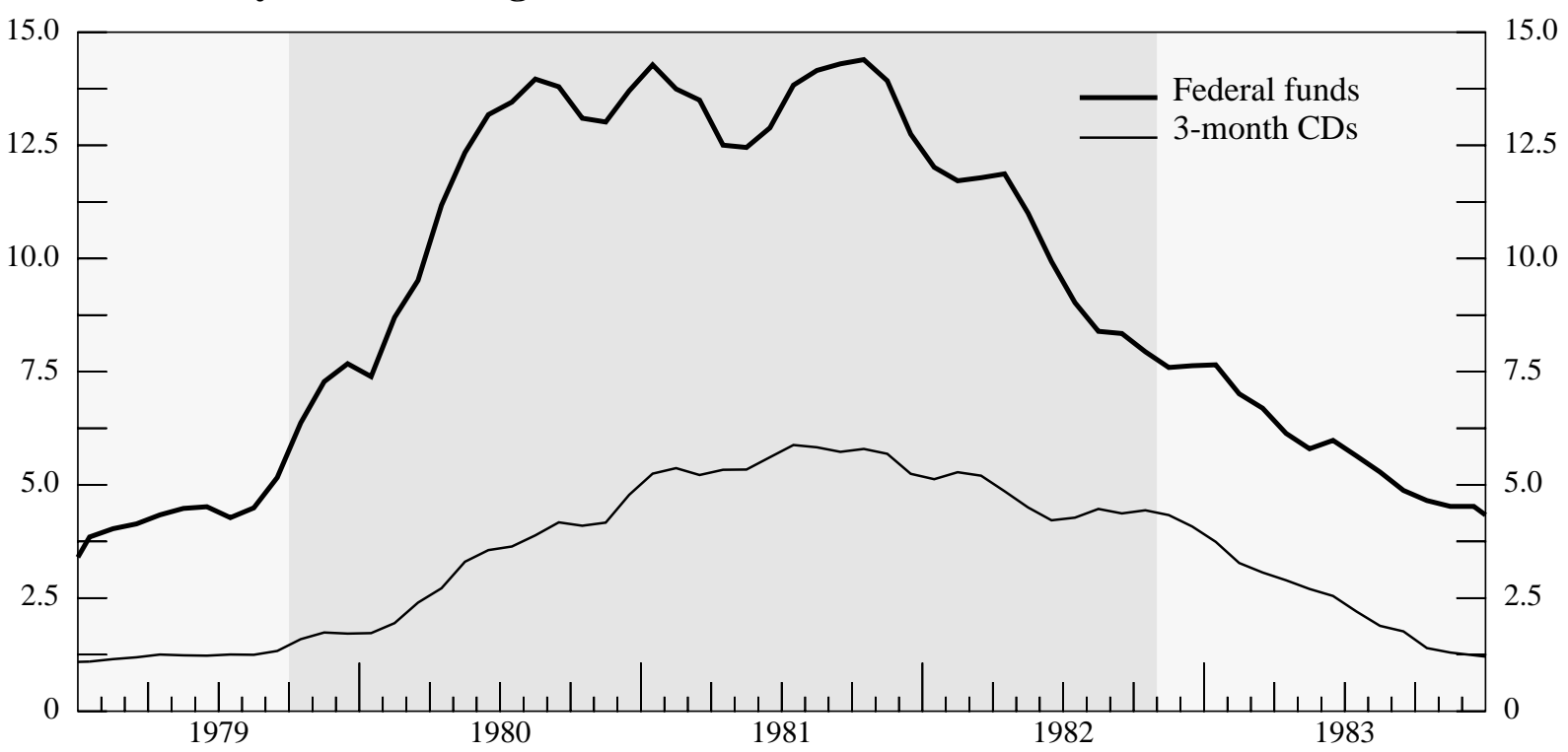

Notes: Measured as the 12-month moving average of the annualised standard deviation of daily changes during calendar months. The shading corresponds to the period of non-borrowed reserves targeting.

40 Somewhat ironically, the shift from semi-lagged to contemporaneous reserve accounting in the United States took place in 1984, well after the move to borrowed reserves targeting had greatly reduced the significance of the change by placing a sharper focus on short-term rates.

41 In contrast to giro deposits, postal chequing accounts pay interest but do not serve as settlement balances for the main RTGS system. If the shift reflected an increase in the non-interest benefits associated with giro accounts, it could be interpreted as a sign that the marginal demand for reserves was actually determined by working balance needs. In practice, however, the shift appears to be motivated at least in part by increasing competition between the large banks and the Post Office. 
The "buffer function" is by far the most common and economically significant. Even at the time when monetary targeting was more popular, central banks saw no difficulties in principle in reconciling the smoothing of transient fluctuations in short-term interest rates with the control of monetary aggregates over somewhat longer horizons via the demand side, by altering the opportunity cost of holding bank deposits. In particular, this has been the position of the Bundesbank, which has often defended the stabilising properties of reserve requirements. The stricter pursuit of monetary control at the expense of historically high volatility in money market rates during non-borrowed reserves targeting in the United States should perhaps best be seen as a specific reaction to the entrenched inflationary expectations of the time (Graph 3.1).

Consistently with the desire to allow banks sufficient room for manoeuvre, most countries have averaging periods as long as one month. In addition, in order to limit the uncertainty surrounding the level of balances to be held, reserve accounting is lagged or semi-lagged, with the precise requirement becoming known either before the beginning of the maintenance period or, more often, in its second half. The two exceptions are those countries where the requirements had at some point been the focus of a more quantitatively oriented policy, viz. the United States and Spain. This probably reduces their effectiveness in smoothing interest rate fluctuations and calls for more intensive forecasting efforts on part of the central bank (Section 4). Partly compensating for this, the United States allows for some carry-over across maintenance periods. France is the only other country making use of such provisions.

Three examples point to the usefulness of reserve requirements in smoothing interest rate variations (Graph 3.2). Prior to 1989, the maintenance period in Switzerland was effectively the last day of the month only, ${ }^{42}$ which led to extreme variability in the day-to-day rate on the last day of the month (the "ultimo" problem). ${ }^{43}$ A similar but more muted pattern is still evident in a number of countries at the end of the maintenance period (Graph 3.3). ${ }^{44}$ Until reserves were allowed to be used for settlement purposes and averaging was introduced in late 1990, in Italy the overnight rate was very volatile; the central bank focused on the three-month Treasury bill rate. The introduction of averaging was a key element in facilitating the shift to the overnight rate as operating target and, until 1992, in helping with the day-to-day management of tighter exchange rate objectives. Finally, the high variability of the overnight rate between late 1990 and 1991 in the United States has generally been seen as resulting from a cut in reserve requirements which made working balances the main variable determining the marginal demand for reserves. Banks' reluctance to turn to the discount window for late-day assistance exacerbated this volatility (Section 4). The reserve market appeared to calm again as the growth in the deposit base once more raised reserve requirements above clearing needs.

The trend towards lower reserve requirements in recent years has raised the concrete possibility that their buffer function could be impaired in a number of countries. This has been exacerbated where items other than deposits at the central bank count as reservable assets. The most common such asset is vault cash, which is included in required holdings in some of the countries permitting averaging; ${ }^{45}$ security risks, transportation costs and competitive equality have generally

42 The liquidity requirement was monitored and enforced only on that day.

43 In the summer of 1987, Switzerland also moved from a net to an RTGS system (SIC). The combination of the change in reserve requirements with the introduction of the new settlement system resulted in an unexpectedly large reduction in the demand for bank reserves. This greatly complicated the central bank's targeting strategy. The greater stability in the interbank rate, however, essentially reflected the change in reserve requirements alone.

44 Such spikes are generally of little monetary policy significance since they are recognised as being due purely to technical factors. As a result, they are not transmitted along the yield curve. In contrast, in Switzerland, the ultimo problem had been increasingly complicating policy in 1986-87.

45 In Germany, vault cash was included in the requirement until 1995. Its exclusion was partly motivated by the wish not to compromise the buffer function of the requirement. 
Graph 3.2

The buffer function of averaging provisions
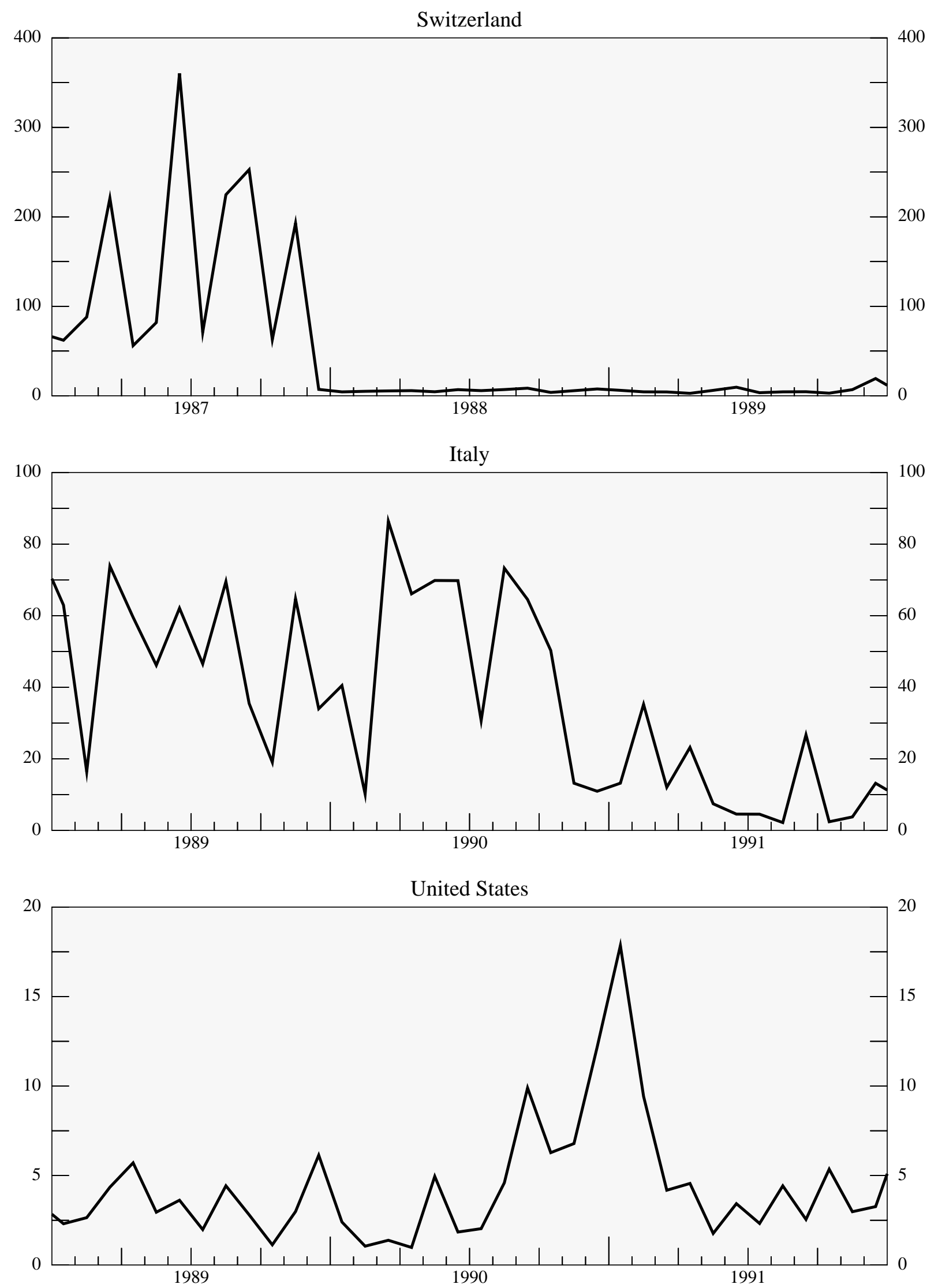

Note: Measured as the annualised standard deviation of daily changes in the overnight rate during calendar months. 
Graph 3.3

End-of-maintenance-period effects on interest rates
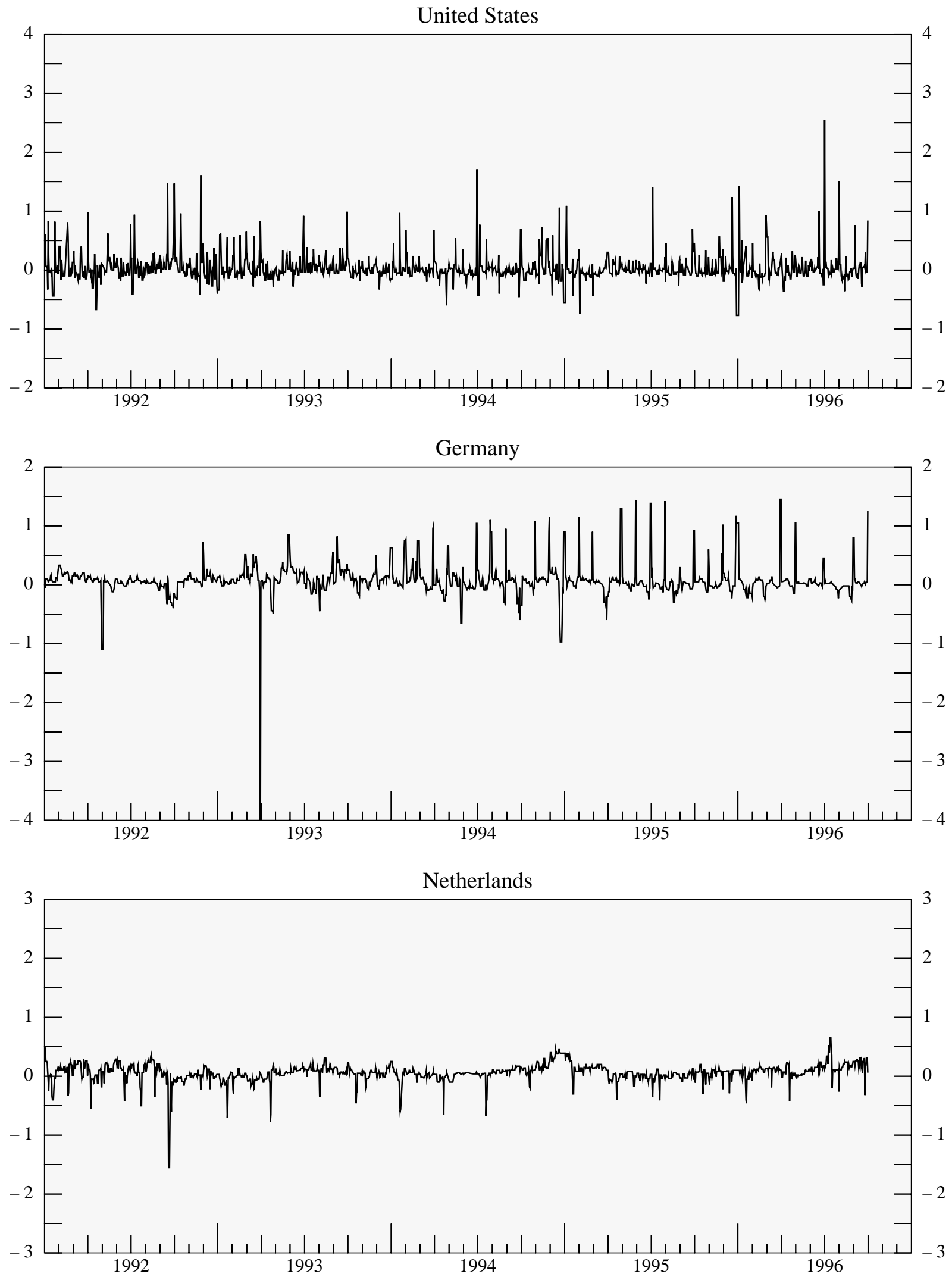

Note: Spikes in the spread between the overnight and policy rate generally correspond to the end of the maintenance period for reserve requirements (or, in the Netherlands, of the averaging period for advances under the quota scheme, which performs a "buffer function" similar to reserve requirements). 
Graph 3.4

\section{Patterns of reserve accumulation 1}

Mean $\quad \pm 2$ standard deviations from the mean

Japan (January $1994-$ September 1996)

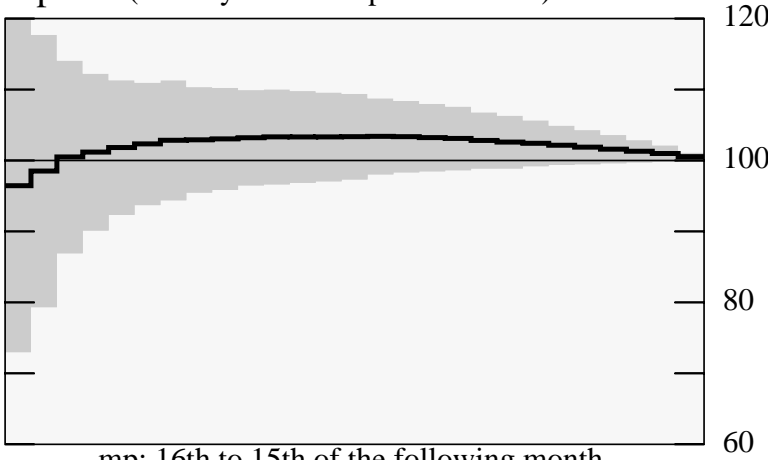

mp: 16th to 15th of the following month

Germany (January 1993 - June 1996)

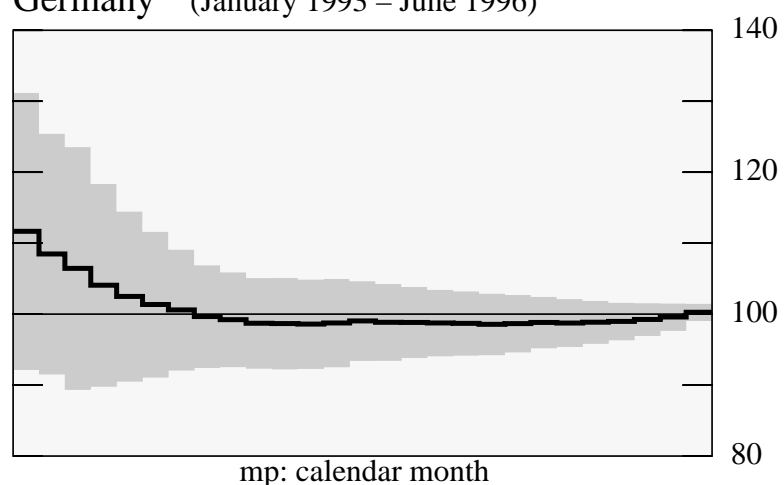

France (January 1995 - September 1996)

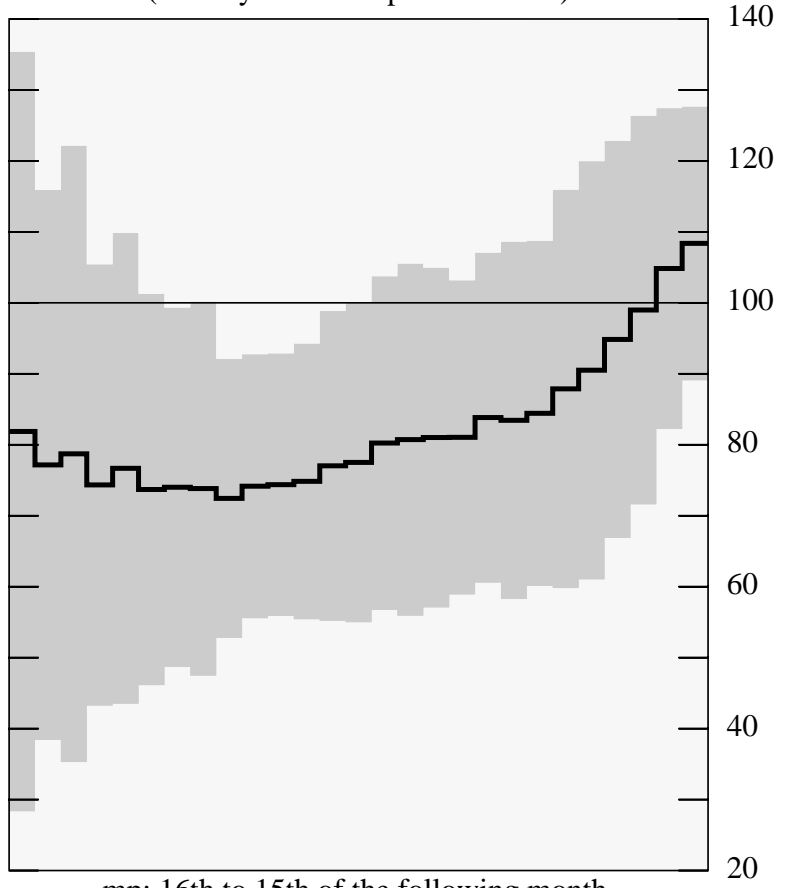

$\mathrm{mp}: 16$ th to 15 th of the following month
Italy (October 1990 - September 1996)

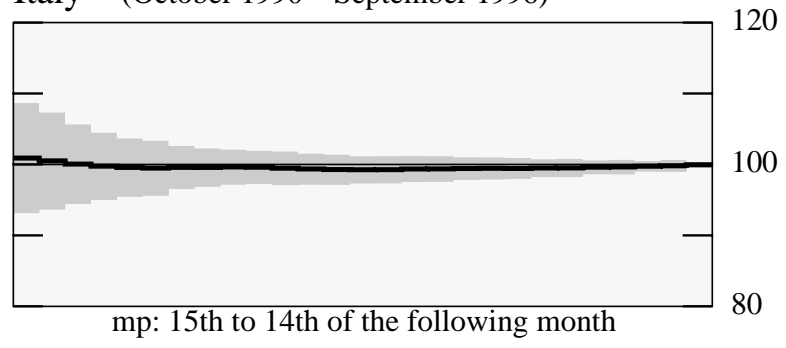

Spain (July 1990 - September 1996)

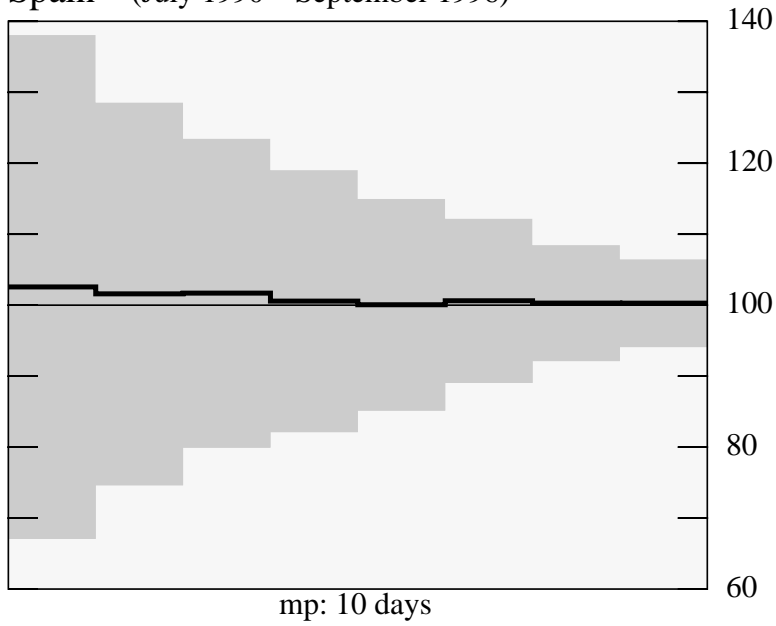

Netherlands ${ }^{2}$ (January 1994 - September 1996)

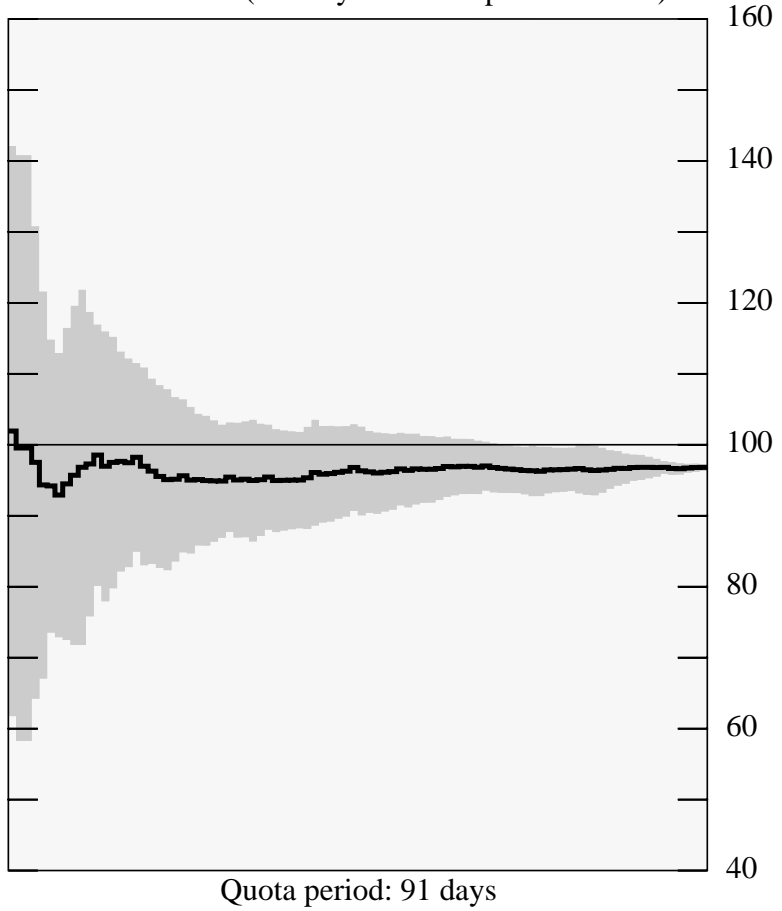

${ }^{1}$ Cumulated average of reserves held as a percentage of required reserves during the maintenance period (mp). ${ }^{2}$ Cumulated average of utilisation rate of the quota determined under the quota scheme (lending facility), which performs a "buffer function" similar to reserve requirements. 
been the main reasons for its eligibility. In France, for instance, vault cash has dramatically reduced the cushion of central bank deposits held for reserve requirement purposes over minimum working balances. ${ }^{46}$ The central bank responded in 1992 by introducing special collateralised current accounts to help banks economise on working balances and by stepping up the monitoring of liquidity needs towards the end of the day, contacting the leading banks directly and then, if necessary, balancing the system through bilateral operations. Similarly, in the United States, even several large banks are now in a position to fulfil their requirements exclusively with vault cash ("non-bound" institutions). ${ }^{47}$

In the United States, stepped-up attempts by banks to economise on reserve holdings in recent years through active liability management have given rise to central bank concerns that volatility in the overnight rate may increase once again to levels comparable to those experienced in the late 1990-91 period (Graph 3.2). The main reason has been the spectacular growth since around 1994 in "sweep" arrangements, whereby banks shift retail deposits at the end of the day from chequing or demand deposit accounts to non-reservable money market accounts (MMDAs). While the decline in operating balances ${ }^{48}$ has not as yet resulted in a sustained rise in volatility, banks have shown signs of greater reluctance to arbitrage over the maintenance period. ${ }^{49}$ Admittedly, the periodic announcements of the federal funds target should limit the concern that the volatility in the overnight rate could cloud policy intentions. Nevertheless, higher volatility could potentially impair the smooth functioning of financial markets more generally.

The recent US experience is a reminder that the "buffer" role of reserve requirements depends to a considerable extent on banks' willingness to arbitrage over the maintenance period. The observed impact of averaging on the stability of the interbank overnight rate is a clear indication that this arbitrage occurs. Nevertheless, especially at system-wide level, there are constraints to the deviations of reserve balances from the average requirement. In fact, central banks typically have a good idea of "normal" fulfilment patterns and, in the absence of special considerations, would not engineer substantial deviations from these (Graph 3.4).$^{50}$ The very existence of such patterns, combined with banks' knowledge of the daily situation, is what allows some central banks to use deviations from them as a possible low-key signal of changes in the monetary stance (Section 5).

\section{The supply of bank reserves: liquidity management}

Consistently with the wish to develop more flexible and less intrusive implementation procedures, central banks have over the years increasingly relied on market operations to balance demand and supply in the market for bank reserves. Together with the trend reduction in reserve requirements and the growing integration of capital markets, this has progressively led to greater liquidity management activism. In turn, this has put a premium on accurate forecasts of the

46 Total reserve requirements have fallen from some FF 80 billion in 1990 to FF 20 billion at the time of writing; as much as FF 13 billion is held in the form of vault cash, which was first included in the requirements in October 1990.

47 It has not been uncommon for smaller institutions to be able to do so.

48 Over and above the reserve requirement, banks also precommit to hold on average over the maintenance period an amount of clearing balances ("required clearing balances"). The incentive to do so takes the form of rebates on certain central bank services. The Fed cannot pay interest on reserves.

49 In particular, they seem less willing to accumulate excess reserves early in the two-week maintenance period, presumably because of the greater risk of incurring overnight overdrafts later in the period when attempting to work the excess reserves off.

50 In France, for instance, banks normally underfulfil the requirement during most of the maintenance period - generally the initial 25 days - and compensate for this delay towards the end (Graph 3.4). This behaviour is reported to be insensitive to interest rates. 
autonomous supply of bank reserves and of the banking system's demand for them, as determined by working balances or reserve requirements.

\subsection{Forecasting liquidity}

Central bank liquidity forecasts invariably represent the initial stage of policy implementation. They form the basis for decisions regarding the volume, maturity and frequency of operations designed to balance the market. The features of the forecasting process vary considerably from country to country, reflecting a mixture of tradition and specific elements of the operating framework (Table 4.1).

In countries where reserve requirements are in place, central banks tend to match the main forecasting horizon with the maintenance period, ${ }^{51}$ in order to get a measure of the cumulative impact of autonomous factors and of the baseline demand for bank reserves. ${ }^{52}$ The forecasts relate to the daily impact of individual factors, thereby helping to determine the need for, and maturity of, rough and fine-tuning operations. In some countries without reserve requirements and averaging provisions, while paying a great deal of attention to the outlook for the current day, ${ }^{53}$ central banks forecast even further ahead. This is the case in the United Kingdom and Australia, where, compared with other countries in the same group, less use has been made of inbuilt buffer mechanisms such as standing facilities. This puts a premium on active and pre-emptive liquidity management, through very flexible maturities (Australia) or the frequency and variety of operations (United Kingdom).

The main forecasts are generally revised daily, although the information regarding the net liquidity position for the maintenance period as whole may be acted upon only at the time of the subsequent regular tender operation (e.g. Germany). Intraday revisions are also possible if the central bank may operate more than once a day, as is routinely done in the United Kingdom.

Except for countries focusing on exchange rate commitments and at times of serious exchange rate pressures, foreign exchange intervention is not a major source of variability in the autonomous liquidity position. Moreover, given the two-day settlement lag of foreign exchange transactions in most markets, it is known with certainty within the horizon of daily operations. While certain countries appear to have some difficulties in forecasting cash, notably Japan, commonly the most troublesome item in terms of both variability and forecastability is net lending to the government (same table). In fact, only in Sweden and Austria do the central banks neither lend to, nor hold deposits of, the government. A number of European countries have recently prohibited lending to the government in accordance with the Maastricht criteria in preparation for monetary union, thereby eliminating an at times very constraining source of liquidity, most notably in Italy (Table 4.2). Nevertheless, the variability of government deposits generally remains significant.

Arrangements aimed at limiting the problem vary from country to country (same table). In a number of cases formal or informal mechanisms have been put in place to ensure that surplus balances are invested in the market, including in the United States, Germany and France. One such scheme is under study in the Netherlands. In Belgium the government is obliged to provide the central bank with a forecast each morning, with significant deviations being penalised through a lower remuneration. In some other countries information is sufficiently accurate and prompt to defuse the issue, notably in Spain. On the other hand, an active and independent management by the government of its surplus funds in the market could also potentially interfere with monetary policy implementation by virtue of the sheer size of the positions or by confounding policy signals. In order to limit this risk,

51 In Spain and Italy, it is a multiple of the maintenance period. In the Netherlands, it coincides with the quota scheme period.

52 In France, the main horizon is determined by the maturity of the twice-weekly tender.

53 In Australia, the current and the following day are equally important given that certain participants can choose the settlement date $(\mathrm{T}$ or $\mathrm{T}+1)$. 
Table 4.1

Features of the forecasting process

\begin{tabular}{|c|c|c|c|c|c|c|c|c|c|c|c|c|c|c|}
\hline & $\mathbf{A U}$ & AT & $\mathbf{B E}$ & CA & FR & DE & IT & $\mathbf{J P}$ & NL & ES & SE & $\mathbf{C H}$ & UK & US \\
\hline Horizon(s) & $2 \mathrm{~m}(\mathrm{r})^{1}$ & $1 \mathrm{~m}(\mathrm{c})$ & $10 \mathrm{~d}(\mathrm{r})^{1}$ & $1 d^{2}$ & $1 d / 8 d^{3}$ & $2 \mathrm{~m}(\mathrm{c})$ & $2 \mathrm{~m}(\mathrm{c}) / 1 \mathrm{y}(\mathrm{c})$ & $1 \mathrm{~d}^{4} / 1 \mathrm{~m}(\mathrm{c})$ & $1 \mathrm{~d} / 3 \mathrm{~m}(\mathrm{c})$ & $1 \mathrm{~d} / 60-80 \mathrm{~d}^{5}$ & $1 \mathrm{w}(\mathrm{r})$ & $5 d$ & $1 d / 13 w(c)^{6}$ & $2 \mathrm{w}$ \\
\hline Maintenance period ${ }^{7}$ & $1 d$ & $1 \mathrm{~m}$ & $1 d$ & $1 \mathrm{~m}$ & $1 \mathrm{~m}$ & $1 \mathrm{~m}$ & $1 \mathrm{~m}$ & $1 \mathrm{~m}$ & $3 m^{8}$ & $10 \mathrm{~d}$ & $1 d$ & $1 \mathrm{~m}$ & $1 d$ & $2 \mathrm{w}$ \\
\hline Forecast interval ${ }^{9}$ & $1 d$ & $1 d$ & $1 d$ & $1 \mathrm{~d}$ & $1 \mathrm{~d}$ & $1 \mathrm{~d}$ & $1 \mathrm{~d}^{10 / 1 \mathrm{~m}}$ & $1 \mathrm{~d} / 1 \mathrm{~m}$ & $1 \mathrm{~d}$ & $1 \mathrm{~d}^{11}$ & $1 \mathrm{~d}$ & $1 \mathrm{~d}$ & $1 \mathrm{~d}$ & $1 \mathrm{~d}$ \\
\hline When made & daily & daily & daily & daily & $\begin{array}{l}\text { daily/ } \\
2 \times w\end{array}$ & daily & $\begin{array}{l}\text { daily/ } \\
\text { Sept. }\end{array}$ & $\begin{array}{l}\text { daily/ } \\
\text { end-m }\end{array}$ & daily & $\begin{array}{c}\text { daily/ } \\
\text { regularly } 12\end{array}$ & daily & daily & daily & daily \\
\hline Revisions & intraday & daily & daily & daily & daily & daily & $\begin{array}{c}2 \times \mathrm{m} \text { and } \\
\text { daily }\end{array}$ & $\begin{array}{l}\text { intraday/ } \\
\text { mid-m }\end{array}$ & daily & $1 \times 10 \mathrm{~d}$ & daily & intraday & $\begin{array}{l}\text { intraday/ } \\
\text { daily }\end{array}$ & daily \\
\hline Most unpredictable item & $G^{13}$ & - & $\mathrm{C}$ & - & $\mathrm{F}$ & $\mathrm{C}, \mathrm{F}$ & $\mathrm{G}^{14}$ & $\mathrm{C}, \mathrm{G}$ & G & $\mathrm{G}^{15}$ & $\mathrm{G}, \mathrm{C}$ & G & $\mathrm{G}^{16}, \mathrm{C}$ & $\mathrm{G}, \mathrm{C}$ \\
\hline Publication of forecast & $*$ & & & & & & $\mid * 17$ & $* 18$ & & & & & $* 19 /$ & 20 \\
\hline Modelling excess reserves & & & & & & & & & & & & & & $*$ \\
\hline Request on target balances & & & & $* 21$ & 22 & & & & & & & $* 22$ & $* 23$ & 24 \\
\hline
\end{tabular}

Key to symbols: $\mathrm{r}=$ rolling; $\mathrm{c}=$ calendar; $\mathrm{C}=$ cash $\mathrm{F}=$ float; $\mathrm{G}=$ government; $\mathrm{RR}=$ reserve requirement.

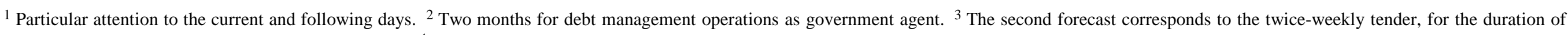

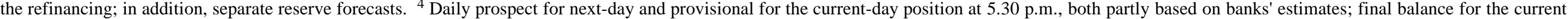

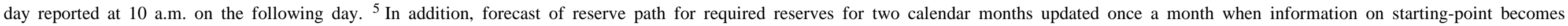

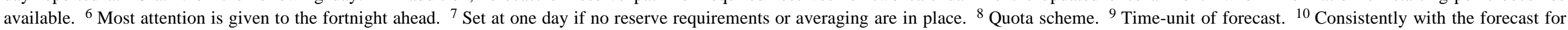

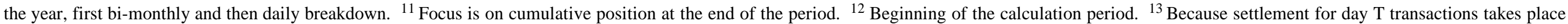

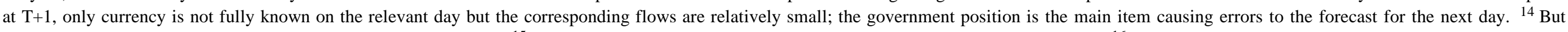

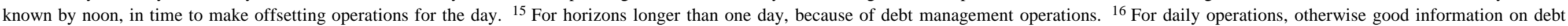

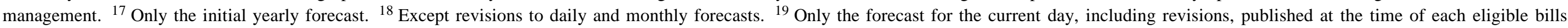

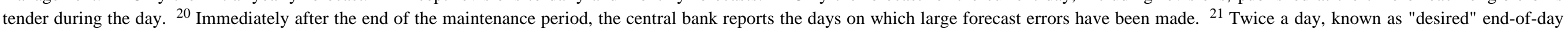
balances (in the morning) and "projected" end-of-day balances (before the clearing). ${ }^{22}$ Informal. ${ }^{23}$ Practice terminated owing to biases. ${ }^{24}$ Occasionally. 
Table 4.2

Relationship with the Treasury: ${ }^{1}$ lending and deposits

\begin{tabular}{|c|c|c|c|c|c|c|c|c|}
\hline & \multirow[b]{2}{*}{ Lending } & \multicolumn{7}{|c|}{ Deposits } \\
\hline & & All & Only part & $\begin{array}{l}\text { Advance } \\
\text { informa- } \\
\text { tion }\end{array}$ & $\begin{array}{c}\text { Target } \\
\text { balance }^{2}\end{array}$ & Penalty & $\begin{array}{c}\text { Central } \\
\text { bank } \\
\text { discretion }\end{array}$ & $\begin{array}{c}\text { Remu- } \\
\text { neration }\end{array}$ \\
\hline $\mathrm{AU}$ & & $*$ & & $*$ & & & & $* 3$ \\
\hline AT & & & & - & - & - & - & - \\
\hline $\mathrm{BE}$ & & & $*$ & $* 4$ & & $* 4$ & & $\begin{array}{l}\text { central } \\
\text { rate }^{4,5}\end{array}$ \\
\hline $\mathrm{CA}$ & & & $*$ & $*$ & & & $* 6$ & $* 7$ \\
\hline FR & $* 8$ & $*$ & & $* 9$ & 10 & & & tender rate \\
\hline $\mathrm{DE}$ & & & $* 11$ & $* 12$ & 13 & & $* 13$ & \\
\hline IT & 14 & $*$ & & $* 15$ & 16 & & & $\begin{array}{l}\text { Treasury } \\
\text { bill rate }\end{array}$ \\
\hline JP & $* 17$ & $*$ & & $*$ & & & & \\
\hline NL & & & & $*$ & 18 & & & tender rate \\
\hline $\mathrm{ES}$ & & & $*$ & $* 19$ & & & & tender rate \\
\hline SE & & & & - & - & - & - & - \\
\hline $\mathrm{CH}$ & $* 20$ & & $*$ & $* 21$ & 22 & - & $* 21$ & $* 23$ \\
\hline UK & $* 24$ & $*$ & & & & & & $* 25$ \\
\hline US & & & $*$ & $* 26$ & $* 27$ & & & \\
\hline
\end{tabular}

${ }^{1}$ In certain cases, other sectors of the public administration are also involved. ${ }^{2}$ Or similar arrangements aimed at making balances more predictable. ${ }^{3}$ Target cash rate minus $0.10 \% .{ }^{4}$ Daily obligation $(9.15 \mathrm{a} . \mathrm{m}$.) for the Treasury to provide a forecast for the current and following two days; the remuneration is lowered if the error exceeds a certain amount. ${ }^{5} \mathrm{Up}$ to a ceiling. ${ }^{6}$ Shifts in demand balances are the key liquidity management tool; surplus balances auctioned to direct clearers, typically for one to seven-day periods (typically one business day). ${ }^{7}$ Below market rates on operating deposits (given their use in the cash setting); market rates on the remaining portion. ${ }^{8}$ To be phased out by the end of 2003. ${ }^{9}$ Daily forecasts for the maturity of regular tenders. ${ }^{10}$ Policy of investing excess balances in repos with primary dealers to smooth out variations. ${ }^{11}$ In 1994 the requirement to hold all liquid funds with the Bundesbank was abolished. ${ }^{12}$ Joint central bank/Federal Government estimates. ${ }^{13}$ Surplus funds invested by the Bundesbank in the market; tool for fine-tuning prior to $1994 .{ }^{14}$ No lending since end-1993, until then lending facility up to $14 \%$ of budgeted expenditure at a $1 \%$ interest rate. ${ }^{15}$ Usually known by noon. ${ }^{16}$ A number of safeguards to prevent balances from falling too low. ${ }^{17}$ Possible according to the Bank of Japan Law but no lending has actually taken place since 1960. ${ }^{18}$ Only informal arrangements. ${ }^{19}$ Stable distribution and accurate real-time information. ${ }^{20}$ Credit line subject to a collateralised credit line, on lombard terms; credit granted only if the Treasury is unable to obtain funds from the market. ${ }^{21}$ Estimate available at 2.15 p.m.; the central bank is willing to operate until 3 p.m. to neutralise the impact; transfers of time deposits are used in fine-tuning before 3 p.m. ${ }^{22}$ Agreement with the Treasury that it refrains from investing in the overnight market. ${ }^{23}$ Current account remunerated at the overnight rate (up to a ceiling); investment account roughly at market rates. ${ }^{24}$ Overnight "ways and means" advance; it would have to be phased out if the United Kingdom joined EMU. ${ }^{25}$ At market rates. ${ }^{26}$ Joint central bank/Treasury estimates. ${ }^{27}$ US $\$ 5$ billion (US $\$ 7$ billion around tax payment dates).

the Swiss National Bank has an agreement that does not permit the Treasury to invest its surplus funds in the overnight market. 
As regards the forecasts of the demand for bank reserves, it is useful to distinguish between projections of the reserve requirement and of working balances. Where reserve requirements are semi-lagged or almost contemporaneous, considerable efforts are devoted to forecasting the reserve requirement itself. This is done on the basis of the expected change in eligible liabilities (essentially deposits), typically through formal models and surveys. In Germany, since the amount of reserve requirements to be held does not become known until around one week before the end of the maintenance period, sizable adjustments may be needed; the Bundesbank bases its initial projection on the target path for M3. In the United States, the demand for excess reserves is also partly modelled. More commonly, the central bank makes judgemental estimates of "typical" patterns of accumulation of reserves during the maintenance period. Where working balances are the binding constraint on the demand for reserves, central banks usually estimate liquidity needs simply by contacting banks, generally informally. This procedure has been an integral part of daily liquidity management in the United Kingdom ${ }^{54}$ and Canada. ${ }^{55}$

Most central banks do not make their forecasts public. The main exceptions are Australia, the United Kingdom and Japan. ${ }^{56}$ Publication is intended primarily to facilitate the liquidity management of banks and, most notably in Japan, to help convey policy intentions revealed by comparing the forecast with the amount of liquidity actually provided or withdrawn (Section 5). In the other countries it is generally felt to be either unnecessary, because of the presence of automatic stabilisers, or inappropriate, not least where estimates are subject to significant error. Attitudes towards the value of disclosure, however, are evolving (Section 5).

\subsection{Discretionary market operations and standing facilities ${ }^{57}$}

Discretionary market operations are now the main instrument for managing liquidity. The only exception is the Bank of Canada, which relies almost exclusively on transfers of government deposits between the central bank and clearers. In this case, the impact on bank reserves of market operations such as reversed transactions or Treasury bill sales is routinely sterilised; their main role, therefore, is signalling (Section 5).

As outlined in Section 3, market operations nowadays are typically geared to balancing the market for bank reserves as a whole. Banks, that is, would not normally be expected to rely on standing facilities, except those provided at subsidised (below-market) rates, unless the central bank made a mistake in forecasting liquidity conditions, inefficiencies in the system prevented a smooth redistribution of reserves or bank-specific factors were at work. The implication is that standing facilities at non-subsidised rates have increasingly played the role of "safety valves" rather than being key mechanisms for setting the marginal interest rate for the market as a whole (Tables 4.3 and 4.4).

How far this strategy is strictly pursued varies across countries and circumstances. At one extreme, Austria has only recently been moving in this direction, with the introduction of regular tender operations in late 1995. Until then, liquidity was regulated almost exclusively through standing facilities. The wish to bring the system closer to the typical European configuration with a view to participating in stage three of monetary union has no doubt played a significant part in this decision. Similarly, systems where the market has to balance each day owing to the absence of reserve

54 The Bank of England has stopped doing so after noticing a persistent downward bias in the declared targets. Since then, it has simply adjusted previous targets downwards.

55 The Bank of Japan also contacts the major banks directly in order to ensure the smooth running of the interbank net settlement systems that settle three times a day.

56 Italy publishes only its annual forecast of monthly movements, which is then used as basis for deriving a consistent initial set of forecasts at higher frequencies.

57 More detailed information on certain aspects of standing facilities and market operations can be found in Annexes III and IV. 
requirements usually rely more often on such facilities. This, for instance, seems to be the case in Sweden ${ }^{58}$ and Belgium. In Belgium, for example, by calibrating the need to turn to the central bank for late-day assistance or to deposit surplus funds, the central bank can put the desired pressure on interest rates. This is also possible in the United Kingdom, where end-of-day assistance is discretionary, but a set of late-day advance facilities at escalating rates has been put in place. ${ }^{59}$ Similar strategies are sometimes followed in systems where averaging provisions act as an effective buffer. The Bundesbank, for instance, may resist downward pressure on the overnight rate by allowing reserve positions to be run down and failing to provide enough liquidity towards the end of the maintenance period, raising the impact of the lombard rate.

Against this background, standing facilities at below-market (subsidised) rates have lost much of their significance in liquidity management (Table 4.5). In Europe, in the four countries that still retain them, discount facilities almost invariably represent a minor source of basic refinancing. Operations have been virtually discontinued in Switzerland and Italy, ${ }^{60}$ are quite limited in Belgium and, in relative terms, have been drastically reduced in Germany, where they now account for less than one-third of central bank refinancing. The only below-market facility still playing a significant role in liquidity management in Europe is that of advances under the quota scheme in the Netherlands. The facility serves as marginal accommodation for the settlement process and, through averaging provisions, helps to limit the volatility in the overnight rate. Its subsidy element, however, is not large.

Developments in the United States and Japan have been rather sui generis. There the main function of the discount windows in liquidity management has traditionally been somewhat different from that of their European counterparts and the loss in importance has occurred largely as a result of events beyond the central banks' immediate control.

In the United States the key function of the discount window in the implementation of monetary policy has been that of limiting pressures on the overnight rate by providing "adjustment credit" to meet reserve deficiencies or avoid end-of-day overdrafts. ${ }^{61}$ Given the below-market cost, assistance has been restricted to situations in which the requesting bank cannot find funds at a reasonable cost in the market; in addition, excessive use has been discouraged. In the past, a fairly well-behaved relationship between the demand for adjustment credit and the spread between the overnight rate and the discount rate was a key element in policy implementation, allowing the Fed to gauge the need for market operations to steer the overnight rate. The situation changed in the early 1990s, when a series of episodes of financial distress among banks entrenched the view that discount window borrowing was a sign of weakness. Since then, despite the return to strength of the banking system, this perception has persisted and has resulted in great reluctance to turn to the window, regardless of the market cost of funds. This has complicated reserve management by the Fed and hindered the role of the window as an effective safety valve.

58 Even so, the central bank's policy in Sweden is to avoid reliance on the facilities as much as possible; their utilisation is frequent but the associated amounts are very small.

59 The number of facilities is partly related to the variety of counterparties, namely discount houses and gilt-edged market makers (GEMMs; 2.45 lending), discount houses (late-late lending, $2.45-3.30$ p.m.) and clearing banks (2.30 - 3.00 p.m. facility). The quantitative significance of the amounts borrowed, especially under the late facility, is small; the facility for clearing banks is rarely used. The overall amount provided through these facilities has to be limited to what is necessary to balance the market at the end of the day.

60 Italy also has an "ordinary advances" facility, providing current account advances at the discount rate (plus a fee for the facility). Before the introduction of averaging, this facility was actively used to meet working balance needs. Since then, it has declined sharply in importance; a doubling of the fee in June 1991 has been partly responsible.

61 The facility is also used to grant "extended" and seasonal credit, neither of which plays any role in the monetary policy framework. 
Table 4.3

Standing facilities: market ceiling 1

\begin{tabular}{|c|c|c|c|c|c|c|c|c|c|c|c|c|}
\hline & $\mathbf{A U}$ & AT & $\mathbf{B E}(\mathbf{1})^{2}$ & $\mathbf{B E}(2)^{2}$ & $\operatorname{CA}(2)^{3}$ & FR & DE & IT & SE & CH & $\mathbf{U K}(\mathbf{1})^{4}$ & UK(2) \\
\hline Name & Rediscount & Lombard & $\begin{array}{l}\text { Ordinary } \\
\text { advances }\end{array}$ & $\begin{array}{c}\text { Hors } \\
\text { plafond }{ }^{5}\end{array}$ & $\begin{array}{l}\text { Overdraft } \\
\text { loans }\end{array}$ & $\begin{array}{l}5 \text { to } 10 \text {-day } \\
\text { repurchase }\end{array}$ & Lombard & $\begin{array}{l}\text { Fixed-term } \\
\text { advances }\end{array}$ & $\begin{array}{l}\text { Lending } \\
\text { facility }\end{array}$ & Lombard & $\begin{array}{c}\text { Late } \\
\text { lending }\end{array}$ & $\begin{array}{c}\text { Clearing } \\
\text { banks facility }\end{array}$ \\
\hline $\begin{array}{l}\text { Pricing } \\
\text { - posted } \\
\text { - floating } \\
\text { - discretion }\end{array}$ & $* 10$ & $*$ & $* 6$ & $*$ & $*$ & * & $* 7$ & * & *8 & $* 11$ & $* 9$ & $* 12$ \\
\hline Suspension possible & & 13 & 14 & 14 & & $* 15$ & $*$ & $*$ & & & & \\
\hline $\begin{array}{l}\text { Limits on credit } \\
\text { - collateral } \\
\text { - quota } \\
\text { - conditions } \\
\text { - discretion }\end{array}$ & $(*)$ & $*$ & $\begin{array}{l}* \\
* 16\end{array}$ & $*$ & $*$ & $(*)$ & $\begin{array}{l}* \\
* 19 \\
* 19\end{array}$ & $\begin{array}{l}* \\
* \\
*\end{array}$ & * & $\begin{array}{l}* \\
* 17\end{array}$ & $\begin{array}{l}* \\
* 18 \\
* 20\end{array}$ & $\begin{array}{l}(*) \\
20\end{array}$ \\
\hline $\begin{array}{l}\text { Maturity } \\
\text { - discretion }\end{array}$ & $\leq 90 \mathrm{~d}$ & $1 d^{21}$ & $1 d$ & $1 d$ & $1 d$ & $\begin{array}{c}5-10 d^{15} \\
15\end{array}$ & $\begin{array}{l}1 \mathrm{~d} \\
*\end{array}$ & $\begin{array}{c}1-32 d^{22} \\
*\end{array}$ & $1 d$ & $\geq 1 \mathrm{~d}$ & $\begin{array}{l}1 \mathrm{~d} \\
*\end{array}$ & $\begin{array}{c}1-33 d \\
*\end{array}$ \\
\hline Settlement & $\mathrm{T}$ & $\mathrm{T}$ & $\mathrm{T}$ & $\mathrm{T}$ & $\mathrm{T}$ & $\mathrm{T}$ & $\mathrm{T}$ & $\mathrm{T}$ & $\mathrm{T}$ & $\mathrm{T}$ & $\mathrm{T}$ & $\mathrm{T}$ \\
\hline $\begin{array}{l}\text { Functions } \\
\text { - } \text { signalling } \\
\text { - limit rise in rate } \\
\text { - emergency settlement }{ }^{1} \\
\text { - other }\end{array}$ & * & * & * & $\begin{array}{l}* \\
* \\
*\end{array}$ & $\begin{array}{l}* \\
*\end{array}$ & $\begin{array}{l}* \\
* \\
*\end{array}$ & $\begin{array}{l}* \\
* \\
*\end{array}$ & $\begin{array}{l}* \\
* \\
*\end{array}$ & $\begin{array}{l}* \\
* \\
*\end{array}$ & $*$ & $\begin{array}{l}* 23 \\
* 23 \\
* 23\end{array}$ & $\begin{array}{l}* 23 \\
* 23 \\
* 23\end{array}$ \\
\hline
\end{tabular}

Key to symbol: $(*)$ indicates rediscounting, reversed transaction or outright purchase of securities.

Footnotes: See opposite. 


\section{Footnotes to Table 4.3}

${ }^{1}$ Further information is contained in Annex II; as can be seen from the specific conditions on which credit is granted, the term "market" ceiling should be interpreted loosely. The terms described in the table refer to the normal use of the facilities; in some cases, when the same facility is used also for emergency settlement, terms can be quite different (see Table 3.1). ${ }^{2}$ A third facility exists for primary dealers, granted for limited amounts at the central rate within an overall ceiling and individual quotas. ${ }^{3}$ In addition, there is a special standing facility for investment dealer-jobbers known as Purchase and Resale Agreements (PRAs). The corresponding credit is granted in the form of reverse transactions, has an overnight maturity, is subject to a pre-determined limit and can be extended only against evidence that the institution has exhausted alternative sources of funds. The amounts granted are routinely sterilised. ${ }^{4}$ Covering both the 2.45 p.m. lending facility (discount houses and gilt-edged market makers) and the "late-late lending" (2.45-3.30 p.m.; discount houses only). ${ }^{5}$ Refers to those advances beyond the quota that are granted against collateral freely predeposited by banks. ${ }^{6}$ Mark-up on central rate (currently 1.25\%). ${ }^{7}$ Possibility to grant "Special Lombard" loans at a rate set on a daily basis. ${ }^{8}$ Surcharge of $1 \%$ if the loan exceeds the $4 \%$ capital threshold. ${ }^{9}$ Official rate (same as stop rate) on first tranche plus $0.50 \%$ on each successive one ("2.45 lending"); incremental $0.25 \%$ penalty for borrowing within each successive 15-minute period until 3.30 ("late-late lending"). ${ }^{10}$ Market rate plus $0.75 \%$ capped at the rate on the rediscounting of seven-day Treasury notes, regardless of actual maturity. ${ }^{11}$ Overnight rate on previous two days plus $2.0 \%$. ${ }^{12}$ Usually higher than market rates. ${ }^{13}$ In principle, the central bank can refuse to grant credit under any standing facility without giving any reason. ${ }^{14}$ In principle possible, in practice not feasible given vital role in settlement process. ${ }^{15}$ Replacement by one-day facility (see Annex V). ${ }^{16}$ For the system as a whole and individual banks. ${ }^{17}$ Credit line granted to a bank on the basis of the collateral it pledges to the central bank. ${ }^{18}$ Quotas and tranche sizes set quarterly in relation to the capital base of the institutions. ${ }^{19}$ Should only fulfil temporary liquidity needs; granted only if appropriate and acceptable in terms of size and duration. ${ }^{20}$ Aggregate only, in order to balance the market at the end of the day. ${ }^{21}$ Before 1996, up to three months. ${ }^{22}$ In 1992-94, average of six days. ${ }^{23}$ Allows the market to balance after discretionary operations; encourages banks to satisfy their liquidity needs earlier in the day to limit end-of-day volatility; may be used, in conjunction with adjustments in the speed of injection of liquidity, to underline policy signals (Section 5).

Table 4.4

Standing facilities: market floor $^{1}$

\begin{tabular}{|c|c|c|c|c|}
\hline & $\mathbf{A U}$ & $\mathbf{A T}$ & $\mathbf{B E}$ & SE \\
\hline Name & $\begin{array}{c}\text { Interest-bearing } \\
\text { settlement balances }\end{array}$ & $\begin{array}{c}\text { REGOM } \\
\text { (deposit facility) }\end{array}$ & $\begin{array}{l}\text { Deposit } \\
\text { facility }^{3}\end{array}$ & $\begin{array}{l}\text { Deposit } \\
\text { facility }^{3}\end{array}$ \\
\hline Pricing & & & & \\
\hline - posted & $* 2$ & $* 4$ & $* 5$ & \\
\hline Suspension & & & $* 3$ & \\
\hline Limits & & & & \\
\hline - quota & & & $* 3$ & $* 3$ \\
\hline - discretion & & 6 & & \\
\hline Maturity & $1 d$ & $1 d$ & $1 d$ & $1 d$ \\
\hline Settlement & $\mathrm{T}$ & $\mathrm{T}$ & $\mathrm{T}$ & $\mathrm{T}$ \\
\hline Functions & & & & \\
\hline - signalling & & & $*$ & $*$ \\
\hline - floor & $*$ & $*$ & $*$ & $*$ \\
\hline
\end{tabular}

${ }^{1}$ Further information is contained in Annex II. The Bundesbank has on occasion issued very short-term (three-day) "liquidity paper" performing a similar function. ${ }^{2}$ Settlement balances earn interest equal to the target overnight rate minus $0.10 \%$; this is functionally equivalent to a permanent deposit facility. ${ }^{3}$ Arrangements are a mirror image of those for central bank advances (Table 4.3). ${ }^{4}$ At discount rate. ${ }^{5}$ Central rate (primary dealers, for limited amounts); central rate minus $1 \%$ (first tranche); central rate minus $2 \%$ (unlimited). ${ }^{6}$ In principle, the central bank can refuse to transact without giving any reasons, as with other facilities. 
Table 4.5

Standing facilities: below market ${ }^{1}$

\begin{tabular}{|c|c|c|c|c|c|c|c|c|c|}
\hline & $\mathbf{A T}(\mathbf{1})$ & BE & DE & $\mathbf{I T}^{2}$ & $\mathbf{J P}^{3}$ & $\mathbf{C H}^{4}$ & $\mathbf{U S}^{5}$ & NL & $\mathbf{A T}(\mathbf{2})^{6}$ \\
\hline Name & $\begin{array}{l}\text { Discount } \\
\text { facility }\end{array}$ & $\begin{array}{l}\text { Discount } \\
\text { facility }\end{array}$ & $\begin{array}{l}\text { Discount } \\
\text { facility }\end{array}$ & $\begin{array}{l}\text { Ordinary } \\
\text { advances }^{2}\end{array}$ & $\begin{array}{l}\text { Discount } \\
\text { window }\end{array}$ & $\begin{array}{l}\text { Discount } \\
\text { facility }\end{array}$ & $\begin{array}{l}\text { Discount } \\
\text { window }\end{array}$ & $\begin{array}{l}\text { Quota scheme } \\
\text { advances }\end{array}$ & GOMEX \\
\hline $\begin{array}{l}\text { Pricing } \\
\text { - posted }\end{array}$ & $*$ & $*$ & * & $* 7$ & $* 8$ & $*$ & $*$ & $*$ & $* 6$ \\
\hline $\begin{array}{l}\text { Limits on credit } \\
\text { - quota } \\
\text { - conditions } \\
\text { - discretion }\end{array}$ & $*$ & $\begin{array}{l}* 9 \\
* 15\end{array}$ & $\begin{array}{r}* 10 \\
15\end{array}$ & $\begin{array}{c}* \\
* 16\end{array}$ & $\begin{array}{l}* 11 \\
* 11\end{array}$ & - & $* 14$ & $* 12$ & $* 13$ \\
\hline $\begin{array}{l}\text { Maturity } \\
\text { - discretion }\end{array}$ & $\leq 3 \mathrm{~m}$ & $15-60 d$ & $\leq 3 \mathrm{~m}$ & indet. ${ }^{17}$ & $\begin{array}{l}\geq 1 \mathrm{~d} \\
* 19\end{array}$ & - & $1 d$ & indet. ${ }^{17}$ & $\geq 1 \mathrm{~d}^{18}$ \\
\hline Settlement & $\mathrm{T}$ & $\mathrm{T}+1$ & $\mathrm{~T}$ & $\mathrm{~T}$ & $\mathrm{~T}$ & - & $\mathrm{T}$ & $\mathrm{T}$ & $\mathrm{T}$ \\
\hline $\begin{array}{l}\text { Functions } \\
\text { - signalling } \\
\text { - basic refinancing } \\
\text { - limit volatility } \\
\text { - marginal accommodation } \\
\text { - other }\end{array}$ & * & $\begin{array}{c}* \\
21\end{array}$ & * & $* 22$ & $\begin{array}{c}* \\
\\
* \\
* 23\end{array}$ & $*$ & $\begin{array}{r}20 \\
* \\
* \\
* 4\end{array}$ & $\begin{array}{l}* \\
* \\
* \\
*\end{array}$ & $* 6$ \\
\hline
\end{tabular}

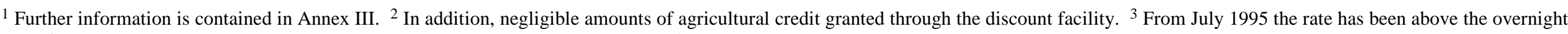

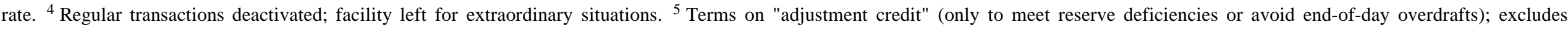

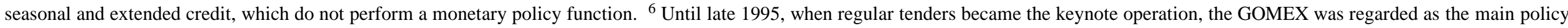

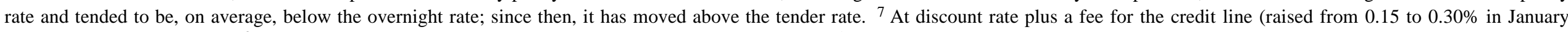

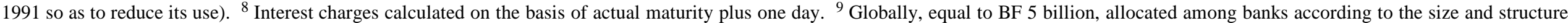

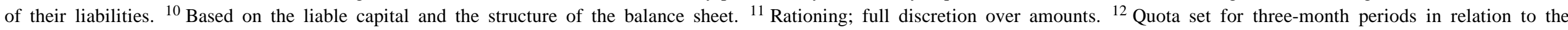

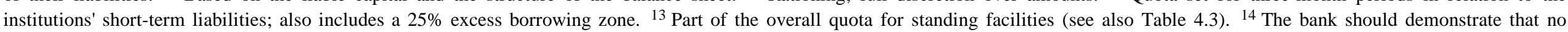

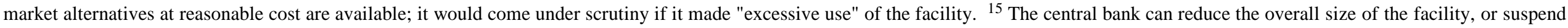

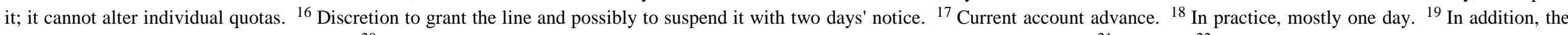

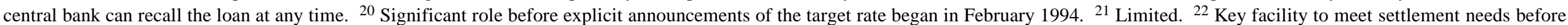
reserve requirements could partly be used for that purpose (buffer role); now used to the full. ${ }^{23}$ Has been used as a flexible means of adjusting liquidity until January 1996. 
In recent years the Bank of Japan has been the only central bank to employ the discount window as a major tool for active liquidity management. The amount and maturity of credits granted through it are entirely discretionary. Moreover, the Bank can also recall them at will. The window, however, has been ineffective since July 1995. At that time the Bank steered the call rate to fall below the discount rate for the first time and to historically low levels in order to stimulate the economy in the face of generalised weakness in the banking system. This situation has persisted to the present day.

As regards market operations, most central banks have at least one transaction that takes place at regular intervals (Table 4.6). The reason is partly related to liquidity management. In the case of countries where reserve requirements are binding, for instance, the timing bears a close relationship to the maintenance period. The aim of the transaction is generally to provide the basic liquidity needs of the system in line with the forecasts over the main implementation cycle. Nevertheless, its significance often goes further. The regular transaction is often the keynote operation, the one that sets the tone of monetary policy, where the authorities' intentions are revealed, on which all market attention is focused. The weekly tender of the Bundesbank is a clear example. Central banks not relying on such keynote regular operations, such as the United States or Switzerland, typically convey policy intentions through other channels (Section 5).

Other operations play supporting roles in different ways. One is that of calibrating day-to-day market conditions at short notice. ${ }^{62}$ This occurs both in countries with and without reserve requirements. In the former, the buffer role of the requirements may not be sufficient, especially when the interval between regular operations is as long as one week or more. In the latter, balancing the market calls for greater attention. Unless the central bank operates regularly at the end of the day, as in Canada, other operations are typically needed. Repos in Switzerland and France and transactions in the interbank market in Belgium and Sweden fall into this category. The significance of this type of operation has greatly increased in recent years, as the need for intervention has risen in line with the reduction in reserve requirements and the greater sensitivity of markets to domestic and international developments. ${ }^{63}$

A second supporting role in liquidity management is that of gross (or "rough") tuning. Operations of this kind provide liquidity over longer horizons than regular transactions and/or respond to predictable patterns in liquidity not otherwise taken into account, such as seasonal fluctuations or the effects of foreign exchange intervention. Typical examples are outright purchases of government securities in the United States, Japan and France and foreign exchange swaps in Italy.

A third supporting function is that of mopping up excessive liquidity with a view to inducing an ex ante net liquidity shortage. This can occur in systems where the keynote operation, by construction, can only be used to inject liquidity, a common situation. Such an asymmetry requires a shortage in the market. Unless autonomous factors and reserve requirements, in conjunction with maturing central bank operations, result in a net deficit, the central bank must generate it. This is the function performed by the weekly Treasury bill tender in the United Kingdom, the sale of central bank paper in the Netherlands and foreign exchange swaps in Belgium.

The maturity of market operations typically differs across types of transaction, reflecting differences in the functions performed. As a rule, it is comparatively short for regular keynote operations (generally between one and two weeks), shorter for day-to-day calibration and longer for the remaining categories. In recent years, there has been a widespread trend towards a reduction in the average maturity, consistently with the need to increase the flexibility of liquidity management and with the longer-term trend towards leaving greater room for market forces in the determination of

62 This is the use for which the term "fine-tuning" is probably most appropriate.

63 In order to be effective, these operations must be settled on a same-day basis. Since swaps are generally settled on a $\mathrm{T}+2$ basis, they are hardly used for day-to-day calibration. 
Table 4.6a

Discretionary operations

\begin{tabular}{|c|c|c|c|c|c|c|c|c|c|c|c|c|}
\hline & \multirow[b]{2}{*}{ Type } & \multirow{2}{*}{$\begin{array}{l}\text { Underlying } \\
\text { instruments }\end{array}$} & \multirow{2}{*}{$\begin{array}{l}\text { Impact on } \\
\text { liquidity }\end{array}$} & \multirow[t]{2}{*}{ Maturity } & \multirow[t]{2}{*}{ Frequency } & \multirow[t]{2}{*}{ Settlement } & \multirow{2}{*}{$\begin{array}{c}\text { Allotment/ } \\
\text { pricing }\end{array}$} & \multicolumn{5}{|c|}{ Function } \\
\hline & & & & & & & & $\begin{array}{c}\text { Basic } \\
\text { refinancing }\end{array}$ & $\begin{array}{c}\text { Gross } \\
\text { tuning }\end{array}$ & $\begin{array}{l}\text { Day-to-day } \\
\text { calibration }\end{array}$ & $\begin{array}{l}\text { Creation } \\
\text { shortage }\end{array}$ & Other \\
\hline \multirow[t]{3}{*}{$\mathrm{AU}$} & $\mathrm{RT}$ & Government securities & $+/-$ & $\mathrm{av} . \approx 7 \mathrm{~d}$ & 1.2 & $\mathrm{~T}$ & $\mathrm{~V}(\mathrm{~A})$ & $* 2$ & & $* 2$ & & \\
\hline & OT & Government securities & $+/-$ & $\leq 1 \mathrm{y}$ & $\int 1 \times d(R)^{1}$ & $\mathrm{~T}$ & $\mathrm{~V}(\mathrm{~A})$ & $* 2$ & & $* 2$ & & \\
\hline & FXS & US\$ & $+/-$ & variable & occasional & $\mathrm{T}$ & bilateral & $* 2$ & & $* 2$ & & \\
\hline \multirow[t]{2}{*}{ AT } & $\mathrm{RP}$ & Gov. and private securities & + & $1 \mathrm{w}$ & $1 \times \mathrm{w}(\mathrm{R})$ & $\mathrm{T}+1$ & $\mathrm{~F}^{3}$ & $\otimes$ & & & & \\
\hline & FXS & $\mathrm{DM}$ & $+/-$ & av. $1 \mathrm{w}$ & as needed ${ }^{4}$ & $\mathrm{~T}+2$ & set rate & & $*$ & & & \\
\hline \multirow[t]{5}{*}{$\mathrm{BE}$} & $\mathrm{RP} / \mathrm{CL}$ & Trade bills/gov. securities & + & $1 \mathrm{w}(\mathrm{n})^{5}$ & $1 \times \mathrm{w}(\mathrm{R})$ & $\mathrm{T}+2$ & $\mathrm{~F}^{6}$ & $\otimes$ & & & & \\
\hline & I & Loans/deposits & $+/-$ & $1 d$ & & $\mathrm{~T}$ & bilateral & & & $*$ & & \\
\hline & $\mathrm{RP}$ & Government securities & + & $3 d(n)$ & $\int 1 \mathrm{x}$ & $\mathrm{T}+1$ & $\mathrm{~V}(\mathrm{~A})$ & & & $*$ & & \\
\hline & FXS & US\$, DM & $+/-$ & $1 w-1 m(n)$ & occasional & $\mathrm{T}+2$ & bilateral & & $*$ & & $*$ & \\
\hline & OT & Treasury certificates & $+/-$ & $1-3 m(n)$ & occasional & $\mathrm{T}+2$ & bilateral & & $*$ & & & \\
\hline \multirow[t]{2}{*}{$\mathrm{CA}^{7}$} & TGD & Demand deposits & $+/-$ & $1 d$ & $1 \times \mathrm{d}(\mathrm{R})$ & $\mathrm{T}-1$ & - & & & $\otimes$ & & \\
\hline & $\mathrm{RT}$ & Gov. securities ${ }^{8}$ & $+/-$ & $1 d$ & as needed ${ }^{8}$ & $\mathrm{~T}$ & $\mathrm{~F}$ & & & & & \\
\hline \multirow[t]{4}{*}{ FR } & $\mathrm{RP} / \mathrm{CL}$ & Gov. and private claims ${ }^{9}$ & + & $1 \mathrm{w}$ & $2 \times \mathrm{w}(\mathrm{R})$ & $\mathrm{T}+1$ & $\mathrm{~F}$ & $\otimes$ & & & & $* 10$ \\
\hline & RT & Gov. and private claims ${ }^{9}$ & $+/-$ & $1 d-1 w$ & as needed & $\mathrm{T}+1$ & bilateral & & $*$ & & & \\
\hline & I & Unsecured deposits & - & $1 d$ & as needed & $\mathrm{T}$ & bilateral & & & $*$ & & \\
\hline & OT & Treasury bills & $+/-$ & $\mathrm{av} . \approx 3 \mathrm{~m}$ & as needed & $\mathrm{T}+1$ & bilateral & $*$ & $*$ & & & \\
\hline \multirow[t]{4}{*}{$\mathrm{DE}$} & $\mathrm{RP}$ & Gov. and private securities ${ }^{11}$ & + & $2 w$ & $1 \times w(R)$ & $\mathrm{T}+1$ & $\mathrm{~V}(\mathrm{~A}) / \mathrm{F}$ & $\otimes$ & & & & \\
\hline & $\mathrm{RP}^{12}$ & Gov. and private securities ${ }^{11}$ & + & $2-10 d$ & as needed & $\mathrm{T}$ & $\mathrm{V}(\mathrm{A}) / \mathrm{F}$ & & $*$ & & & \\
\hline & $\mathrm{S}$ & Liquidity paper ${ }^{13}$ & - & $3 d$ & as needed & $\mathrm{T}$ & set rate & & & & & $* 14$ \\
\hline & FXS & US $\$ 15$ & $+/-$ & $\geq 1 \mathrm{~d}$ & as needed & $\mathrm{T}+2$ & bilateral & & $*$ & & & \\
\hline \multirow[t]{3}{*}{$\mathrm{IT}^{16}$} & RT & Government securities & $+/-$ & $\leq 1 \mathrm{~m}$ & $\approx 1 \times 5 \mathrm{~d}$ & $\mathrm{~T}$ & $\mathrm{~V}(\mathrm{~A})$ & $\otimes^{17}$ & $*$ & & & \\
\hline & FXS & DM/US\$ & $+/-$ & $1 \mathrm{~m} / 3 \mathrm{~m}$ & as needed ${ }^{18}$ & $\mathrm{~T}+2$ & $\mathrm{~V}(\mathrm{~A})$ & $*$ & * & & & \\
\hline & OT & Treasury bills & $+/-$ & $2-6 m$ & as needed & $\mathrm{T}$ & $\mathrm{V}(\mathrm{A})$ & 19 & 19 & $*$ & & \\
\hline
\end{tabular}

Key to symbols and footnotes: See page 48. 
Table 4.6b

Discretionary operations

\begin{tabular}{|c|c|c|c|c|c|c|c|c|c|c|c|c|}
\hline & \multirow[b]{2}{*}{ Type } & \multirow{2}{*}{$\begin{array}{l}\text { Underlying } \\
\text { instruments }\end{array}$} & \multirow{2}{*}{$\begin{array}{l}\text { Impact on } \\
\text { liquidity }\end{array}$} & \multirow{2}{*}{ Maturity } & \multirow{2}{*}{ Frequency } & \multirow{2}{*}{ Settlement } & \multirow{2}{*}{$\begin{array}{l}\text { Allotment/ } \\
\text { pricing }\end{array}$} & \multicolumn{5}{|c|}{ Function } \\
\hline & & & & & & & & $\begin{array}{c}\text { Basic } \\
\text { refinancing }\end{array}$ & $\begin{array}{l}\text { Gross } \\
\text { tuning }\end{array}$ & $\begin{array}{l}\text { Day-to-day } \\
\text { calibration }\end{array}$ & $\begin{array}{l}\text { Creation } \\
\text { shortage }\end{array}$ & Other \\
\hline \multirow[t]{7}{*}{ JP } & $\mathrm{RP}$ & Bill purchases ${ }^{1}$ & + & $\leq 3 \mathrm{~m}^{2}$ & $\leq 2 \times \mathrm{d}$ & $\mathrm{T} / \mathrm{T}+1$ & $\mathrm{~V}(\mathrm{~A})$ & $*$ & $*$ & $*$ & & \\
\hline & $\mathrm{RP}$ & Treasury bills & + & variable $^{2}$ & $\leq 2 \times \mathrm{d}$ & $\mathrm{T} / \mathrm{T}+2$ & $\mathrm{~V}(\mathrm{~A})$ & $*$ & $*$ & $*$ & & \\
\hline & $\mathrm{RP}$ & Government bonds & + & variable ${ }^{3}$ & as needed & $\mathrm{T}+2$ & $\mathrm{~V}(\mathrm{~A})$ & & $*$ & & & \\
\hline & $\mathrm{RP}$ & Commercial paper & + & $\leq 3 \mathrm{~m}^{4}$ & as needed & $\mathrm{T}+2$ & $\mathrm{~V}(\mathrm{~A})$ & & $*$ & & & \\
\hline & RRP & Financing bills & - & $\leq 2 \mathrm{~m}$ & as needed & $\mathrm{T} / \mathrm{T}+1$ & set rate & & $*$ & & & \\
\hline & S & Central bank bills & - & $\leq 3 \mathrm{~m}^{5}$ & as needed & $\mathrm{T} / \mathrm{T}+1$ & $\mathrm{~V}(\mathrm{~A})$ & & $*$ & $*$ & & \\
\hline & OT & Government bonds & + & $9-19 y$ & as needed & $\mathrm{T}+3$ & $\mathrm{~V}(\mathrm{~A})$ & & & & & $* 6$ \\
\hline \multirow[t]{5}{*}{ NL } & CL & Very broad range $^{7}$ & + & $2-8 \mathrm{~d}$ & $\approx 1 \times 4 \mathrm{~d}^{8}(\mathrm{R})$ & $\mathrm{T}$ & $\mathrm{F}$ & $\otimes$ & & & & \\
\hline & CL & Very broad range $^{7}$ & + & variable & as needed & $\mathrm{T}$ & $\mathrm{F}$ & & $*$ & & & \\
\hline & S & Central bank paper & - & $6 \mathrm{~m}$ & $1 \times \mathrm{m}(\mathrm{R})$ & $\mathrm{T}+3$ & $\mathrm{~V}(\mathrm{D})$ & & & & $*$ & \\
\hline & FXS & $\mathrm{DM}, \mathrm{US} \$$ & $+/-$ & $<10 \mathrm{~d}^{9}$ & as needed & $\mathrm{T}+2^{10}$ & bilateral & & $* 9$ & & & \\
\hline & I & Loans ${ }^{11} /$ deposits & $+/-$ & $1 d(n)$ & as needed & $\mathrm{T}$ & bilateral & & & $*$ & & \\
\hline \multirow[t]{2}{*}{ ES } & $\mathrm{RP}$ & Government securities & + & $10 \mathrm{~d}$ & $\approx 1 \times 10 \mathrm{~d}(\mathrm{R})$ & $\mathrm{T}+1$ & $\mathrm{~V}(\mathrm{~A})$ & $\otimes$ & & & & \\
\hline & RT & Central bank paper & $+/-$ & $1 d$ & $\approx 1 \times \mathrm{d} \mathrm{d}^{12}$ & $\mathrm{~T}$ & $\mathrm{~V}(\mathrm{~A})$ & & & $*$ & & $* 13$ \\
\hline \multirow[t]{2}{*}{ SE } & RT & Central bank paper & $+/-$ & $1 \mathrm{w}$ & $1 \mathrm{xw}$ & $\mathrm{T}+1$ & $\mathrm{~F} / \mathrm{V}(\mathrm{A})$ & $\otimes$ & & & & \\
\hline & I & Loans/deposits & $+/-$ & $1 d$ & as needed & $\mathrm{T}$ & bilateral & & & $*$ & & \\
\hline \multirow[t]{3}{*}{$\mathrm{CH}$} & FXS & US\$ & $+/-$ & $2-4 m(n)^{14}$ & $\approx 1 \mathrm{x} \mathrm{w}$ & $\mathrm{T}+2$ & $\mathrm{~F}$ & $*$ & $*$ & & & 14 \\
\hline & RT & Treasury bills & $+/-$ & $1 d-1 m$ & & $\mathrm{~T}$ & bilateral & & & $*$ & & \\
\hline & TGD & Time deposits & $+/-$ & $1 d-6 m$ & $\int 1 \times d$ & $\mathrm{~T}$ & bilateral & & & $*$ & & \\
\hline \multirow[t]{4}{*}{ UK } & $\mathrm{OT}^{15}$ & Eligible bills ${ }^{15}$ & + & $1-33 d$ & $\leq 3 \times \mathrm{d}$ & $\mathrm{T}$ & $\mathrm{V}^{*}(\mathrm{~A})$ & $\otimes 16$ & & $*$ & & \\
\hline & $\mathrm{RP}$ & Gilts $^{17}$ & + & $2-3 / 4-5 w^{18}$ & $2 \times \mathrm{m}(\mathrm{R})$ & $\mathrm{T}$ & $\mathrm{F}$ & & $*$ & & & \\
\hline & S & Treasury bills & - & $3 \mathrm{~m}(\mathrm{n})$ & $1 \mathrm{x} \mathrm{w}(\mathrm{R})$ & $\mathrm{T}$ & $\mathrm{V}(\mathrm{A})$ & & & & $*$ & \\
\hline & $\mathrm{S}$ & Treasury bills & - & $\leq 7 \mathrm{~d}(\mathrm{n})^{19}$ & occasional & $\mathrm{T}$ & $\mathrm{V}^{*}(\mathrm{~A})$ & & $*$ & & & \\
\hline \multirow[t]{3}{*}{ US } & $\mathrm{RT}^{20}$ & Government securities ${ }^{20}$ & $+/-$ & $1-15 d$ & several $x 2 \mathrm{w}$ & $\mathrm{T}$ & $\mathrm{V}(\mathrm{A})$ & $*$ & $*$ & $*$ & & \\
\hline & $\mathrm{RP}^{21}$ & Government securities $^{21}$ & + & $1 \mathrm{~d}$ & several $\mathrm{x} 2 \mathrm{w}$ & $\mathrm{T}$ & $\mathrm{V}(\mathrm{A})$ & $* 22$ & $* 22$ & $* 22$ & & \\
\hline & OT & Treasury bills (mainly) ${ }^{23}$ & $+/-$ & $<1 \mathrm{y}$ & $5-10 \times y^{24}$ & $\mathrm{~T}+1^{25}$ & $\mathrm{~V}(\mathrm{~A})$ & $*$ & $*$ & & & \\
\hline
\end{tabular}

Key to symbols and footnotes: See page 48. 


\section{Key to symbols to Tables 4.6a and b}

$(\mathrm{n})=$ normally $; \mathrm{F}=$ fixed rate (volume) tender; $\mathrm{V}=$ variable rate (interest rate) tender; $\mathrm{V}^{*}=$ pre-announced volume and/or minimum rate; $\otimes=$ keynote operation (basic refinancing and significant signalling content); $(\mathrm{A})=$ American style; $(\mathrm{D})=$ Dutch style.

\section{Footnotes to Table 4.6a}

${ }^{1}$ One or the other, once a day, but occasionally both. ${ }^{2}$ Distinction difficult given the absence of reserve requirements or averaging; swaps used as a substitute for the other operations. ${ }^{3} \mathrm{~V}(\mathrm{~A})$ not excluded. ${ }^{4}$ In principle possible, but not used for the last two years. ${ }^{5}$ On occasion, $15 \mathrm{~d}$ or $1 \mathrm{~m} .{ }^{6}$ As a rule, at the central rate; occasionally V(A). ${ }^{7}$ Until mid-1995, also sales of Treasury bills to signal views about the three-month rate. ${ }^{8}$ Known as Special Purchase and Resale Agreements (SPRAs) and Sale and Repurchase Agreements (SRAs); normally transacted at 9 a.m., their impact on the end-of-day liquidity position is typically sterilised via the redeposit/drawdown facility to achieve the target overnight interest rate; used to signal and enforce the operating band. ${ }^{9}$ Government securities and commercial paper for repos; bank claims on companies with favourable credit rating by the Bank of France (maximum residual maturity of two years). ${ }^{10}$ To set the lower limit for the overnight rate. ${ }^{11}$ Including, inter alia, certain debt securities traded on the stock exchange. ${ }^{12}$ So-called "quick tenders". ${ }^{13}$ Paper issued by the Federal Government on request by the Bundesbank, which is economically liable for it. ${ }^{14}$ Acts as a floor to the overnight rate, when appropriate. ${ }^{15}$ Swaps used almost exclusively to increase liquidity and repurchase transactions to drain it. ${ }^{16} \mathrm{In}$ addition, a number of bilateral reversed and outright transactions with primary dealers in the bond market to improve the market's functioning or occasionally to limit sharp fluctuations in bond prices; the impact on liquidity is sterilised. ${ }^{17}$ Limited signalling role reinforced by quantity signals (see Section 5). ${ }^{18}$ In 1995, between one and two operations per month in US dollars and between two and three in Deutsche marks. ${ }^{19}$ Alternative to repos when the size of the operation is very small.

\section{Footnotes to Table 4.6b}

${ }^{1}$ Bills issued by financial institutions (secured by corporate bills or government bonds). ${ }^{2}$ Usually $1 \mathrm{~d}-3 \mathrm{w} .{ }^{3}$ Usually $1 \mathrm{w}-3 \mathrm{~m} .{ }^{4}$ Usually 3-4w. ${ }^{5}$ Usually 1-4w. ${ }^{6}$ Regular purchases of government bonds in fulfilment of the legal obligation to supply base money to support economic growth. ${ }^{7}$ Including government and (good quality) private paper, mortgage bonds, listed shares and subordinated paper, and required reserves. ${ }^{8}$ On average, schedule not fixed. ${ }^{9}$ Normally used until the level of the reserve requirement can be changed; the maturity is chosen accordingly. ${ }^{10} \mathrm{~T}+1$ (Tomorrow/Next) operations possible in limited amounts. ${ }^{11}$ Collateralised. ${ }^{12}$ Occasionally, up to three times per day. ${ }^{13}$ May be used for signalling (see Section 5). ${ }^{14}$ Longer maturities (up to 12 months) for signalling purposes (see Section 5). ${ }^{15}$ Treasury bills and eligible bank bills, i.e. bills accepted by an eligible bank, denominated in sterling, for an original maturity not exceeding 187 days and subject to certain other restrictions. Supplemented (irregularly) with bill/floating rate gilt repos of 2-3w maturity when the required volumes are unusually large. ${ }^{16}$ The tender has lost some of its signalling significance since changes in official rates have been announced separately. ${ }^{17}$ Including also UK government marketable debt in currencies other than sterling. ${ }^{18}$ Institutions can choose between the two maturity tranches. ${ }^{19}$ Could be up to three months. ${ }^{20}$ System repurchase agreement (injection), Matched Sale-Purchase agreement (withdrawal); against Treasury and Agency securities (injections) and Treasury bills (withdrawals). ${ }^{21}$ Customer repurchase agreement, against Treasury bills or coupons. ${ }^{22}$ Usually to address comparatively small shortages. ${ }^{23}$ Treasury bills or coupons (purchases); in practice, Treasury bills only (sales). ${ }^{24}$ Sales more infrequent. ${ }^{25}$ Regular or skip-day. 
interest rates. The reluctance to conduct outright transactions in securities markets is part and parcel of the same attitude.

The choice of counterparties is also partly determined by the nature of the transaction (see Annex IV). Regular transactions, given lead times, are generally executed with a broader set of counterparties than irregular ones. Beyond this, the range and number of counterparties vary substantially across countries, reflecting different views regarding the merits of broad participation or of privileged relationships with market-makers ${ }^{64}$ and other aspects of the organisation of national money markets. At one end of the spectrum is the United States, where the Fed deals only with a restricted group of primary dealers. At the other end is Germany, where participation in the regular auctions is open to all credit institutions subject to reserve requirements. ${ }^{65}$ The United Kingdom is rather special in that each market operation and standard facility has a specific set of counterparties, ranging from discount houses only for the keynote eligible bill operations to no restrictions on participation in the weekly Treasury bill tenders.

The choice of the method for determining the price of the transactions is partly affected by the nature of the operation. Foreign exchange swaps, for instance, are mostly done at the ruling market prices quoted on the screens on a bilateral basis. Similarly, the observed differences in preferences for specific types of tender (volume vs. interest rate tender, adjudication at a uniform or varying price) may in part be due to varying views regarding their technical merit. Nonetheless, probably the most important consideration is the clarity of the signal associated with the various techniques (Section 5).

As regards the type and number of instruments employed, the most remarkable development in recent years has already been discussed in Section 2, viz. the increasing reliance on reversed transactions. Beyond this, Table 4.6 reveals a great variety of approaches across countries. The spectrum ranges from countries where at most one type of operation is sufficient for liquidity management, such as Canada, to those relying on a broad range of transactions, such as Japan and the United Kingdom.

The range of underlying securities traded and collateral accepted varies considerably across countries. This reflects, inter alia, the relative availability of the various assets, settlement characteristics as well as broader legal and historical factors. In Japan and several European countries, notably the Netherlands, Germany, France and Austria, the range is quite broad, including various types of public as well as private claims. By contrast, in the United States, Canada and Australia, the central bank operates exclusively on the basis of public sector assets. Under normal conditions, the availability or distribution of eligible assets in not a constraint on policy; the United Kingdom has possibly been an exception in this regard, given the traditional practice of dealing with discount houses in commercial bills, the issuance of which has not kept pace with the growth of bank balance sheets in recent years. However, at times when exchange rate commitments are tested, collateral constraints can have a first-order impact on policy (Annex V).

64 These would include, for instance, facilitating the development of markets and/or reducing the risks faced by the central bank.

65 Practice in France represents an interesting attempt to strike a balance between operational efficiency and participation. In the twice-weekly tenders, all banks can bid but the bids are channelled through a few principal market operators (OPMs). 


\section{The supply of bank reserves: signalling and tactics}

It is probably not an exaggeration to say that at the heart of monetary policy implementation lies not so much liquidity management per se but the communication strategy through which the central bank conveys its policy intentions ("signalling"). The technical reasons for this were outlined in Section 1, viz. the very low, if any, interest elasticity of (a possibly unstable) demand for working balances and the importance of expectations about future very short-term interest rates in cases of binding reserve requirements with averaging provisions. In this context, signalling is indispensable to achieving interest rate objectives and limiting volatility.

\subsection{How much transparency with respect to operating targets?}

At the same time, there are broader economic reasons why communication is now probably more important than ever before. These factors also explain why, on balance, over the last 20 years it is possible to discern a certain pattern in the attitude towards the appropriate clarity of policy signals regarding interest rates.

The initial move towards more market-oriented means of policy implementation away from standing facilities and, in some countries, the greater focus on quantitative objectives for operating and/or intermediate aggregates went naturally hand in hand with implementation strategies where central banks gave less guidance about desired interest rates. At a time when reducing inflation was paramount, these policies were also seen as a way of shielding central banks from social and political resistance to unpalatable increases in interest rates.

With the return of inflation to historically low levels and the emergence of a more favourable political climate, other factors have come to weigh more heavily and to redress the balance towards greater transparency. The increased accountability that accompanies the greater independence of central banks in several countries is one. But most probably the decisive factor has been the rapid development and internationalisation of financial markets in the wake of deregulation and financial innovation. The process has heightened the role of interest rates in the propagation of policy impulses, has made interest and exchange rates highly sensitive to expectational factors and may well have raised the vulnerability of financial markets to sharp movements in rates. It has also brought national central banks, willy-nilly, under the scrutiny of a much broader audience, sometimes less familiar with local market idiosyncrasies in the communication of policy intentions but just as eager to decipher them. ${ }^{66}$ Against this background, the need to influence expectations as well as the cost and probability of a misreading of policy have increased.

The gradual shift towards greater transparency in policy implementation, part of a broader process encompassing monetary policy more generally, has been most evident in English-speaking countries. The United States is the clearest example: the move from non-borrowed to borrowed reserves targeting in the early 1980s ushered in a period in which policy signals regarding changes in federal funds rate targets had to be read from a mixture of signals conveyed via market operations and explicit discount rate announcements. Policy became more transparent in the 1990s, as it had been in the 1970s, until finally changes began to be announced in February $1994 .{ }^{67}$ The explicit announcement of operating targets in Australia since 1990, (de facto) of changes in stop rates in the United Kingdom since 1992 and of operating bands in Canada since 1994 are part and parcel of the same process.

66 The Bundesbank has sometimes drawn attention to efforts by new market participants to read too much into purely technical characteristics of its variable rate repo tenders (e.g. amounts renewed relative to those maturing).

67 The fact that the rate had remained unchanged for so long provided a good opportunity to move to a more transparent approach. The new clarity is also consistent with the desire to avoid informational advantages for certain participants. 
It is, of course, recognised that the practice of making announcements may have costs. The loss of the ability to effect, and possibly reverse, policy changes in a less visible way is one. The risk of delaying necessary adjustments, especially in the upward direction, is a second. The possibility that it may give markets clear targets to test the resolve of the authorities is a third. It is considerations such as these that have led one country, Switzerland, to seek to retain an operating objective defined in terms of giro deposits. At the same time, considerable day-to-day variations in these deposits are tolerated, the target is not published ${ }^{68}$ so as to allow for more leeway and, especially at times of turbulence in the markets, interest rate signals are employed (see below). Moreover, the policy has had to be temporarily abandoned on a number of occasions since the late 1980s, as is the case at present.

\subsection{Varieties of signalling strategies}

Signals come "in all shapes and sizes" (Table 5.1). Their characteristics depend on the strength, clarity and nuances with which central banks wish to convey their policy intentions and on available instruments.

Nowadays, with the exception of Japan, the main policy signal is conveyed either through announcements of specific targets for operating objectives or through keynote tender operations. In contrast to policy announcements, the clarity of the signal transmitted through tenders depends on the characteristics of the procedures. It is clearest in fixed rate (volume) tenders, where participants are asked to bid at the rate set by the central bank. It may be considerably more ambiguous in the case of interest rate tenders with ex post published marginal interest rates. ${ }^{69}$ In this case it is more difficult to distinguish whether the outcome reflects the acceptance of minor fluctuations around a desired level, the beginning of the implementation of a change in a certain direction or difficulties on the part of the central bank in reconciling the interest rate bids with its liquidity management objectives. ${ }^{70}$

Among the countries using keynote tender operations to convey signals, the picture is rather varied. Three countries, the Netherlands, Belgium and Austria, employ exclusively fixed rate tenders. ${ }^{71}$ Sweden and Germany shift between techniques depending on circumstances. In Sweden fixed rate tenders are used to convey clear signals about policy changes while variable rate auctions are relied upon primarily when market rates fluctuate around levels in line with policy intentions. In the past, the Bundesbank had shown some preference for variable rate tenders, seen as more consistent with a hands-off, market-oriented policy. ${ }^{72,73}$ It has, however, resorted to fixed rate auctions when the

68 This is not inconsistent with policies in other countries: less transparency about a quantitive target allows greater room for smoothing out undesired changes in interest rates.

69 There is no policy signal if the central bank does not publish the interest rates at which the bids are met, which is typically the case when the operations have an exclusive liquidity management function.

70 A further distinction is between interest rate tenders in which allotments are made at a common rate ("Dutch method") and those in which they are made at the individual rates bid by participants ("American method") (see table). The choice between the two has more to do with technical characteristics such as their impact on central bank revenue than with signalling policy.

71 In Austria, the central bank does not rule out the possibility of using variable rate tenders but has not yet done so. In Switzerland, the central bank actually sets the rate on its swaps through quasi-auctions, albeit as close as possible to the market level. This is partly to avoid the risk of collusion, given the highly concentrated nature of the banking system (only three major banks).

72 In December 1992 the Bundesbank reduced the size of bidding steps from 5 to 1 basis point. This was designed not only to increase the differentiation in bids, but also to prevent the concentration of bids around a given level, which in effect would make the variable rate tender resemble more closely a fixed rate one.

73 Another useful function of variable rate auctions is to provide the central bank with information about the dispersion of market views about policy and/or liquidity conditions. 
Table 5.1

Signalling mechanisms

\begin{tabular}{|c|c|c|c|c|c|c|c|c|c|c|c|c|c|c|}
\hline \multirow[b]{2}{*}{ Interest rate signals } & $\mathbf{A U}$ & $\mathbf{A T}$ & BE & CA & FR & DE & IT & $\mathbf{J P}$ & NL & ES & SE & $\mathbf{C H}$ & UK & US \\
\hline & & & & & & & & & & & & & & \\
\hline $\begin{array}{l}\text { Announcement of } \\
\text { target }\end{array}$ & $*$ & & & $* 1$ & & & & 2 & & & & & 3 & $*$ \\
\hline Regular tender & & $*$ & $*$ & & $*$ & $*$ & $* 4$ & & $*$ & $*$ & $*$ & & $* 3$ & \\
\hline - Fixed rate & & $* 5$ & $*$ & & $*$ & $* 5$ & & & * & & $* 5$ & & & \\
\hline - Variable rate & & $* 5$ & & & & $* 5$ & $* 4$ & & & $* 6$ & $* 5$ & & *3 & \\
\hline $\begin{array}{l}\text { Other } \\
\text { operations }\end{array}$ & & & & $* 1$ & $*$ & & & & & $* 6$ & & & & \\
\hline Standing facilities & & $*$ & $* 7$ & & $*$ & $*$ & $*$ & $*$ & $*$ & & $*$ & $* 8$ & & \\
\hline Other & & & & & & & & & & & & & 9 & \\
\hline Quantity signals & & & & & & & & & & & & & & \\
\hline End-of-day positions & & & $*$ & $* 10$ & & $*$ & & & & & & & & \\
\hline Intraday injections & & & & & & & & & & & & & $*$ & \\
\hline Reserve accumulation & & & & & & $* 11$ & $* 4$ & & & & & & & \\
\hline Other & & & & & & $* 12$ & & $* 13$ & & & & & & \\
\hline Maturity & & & & & & & & $* 14$ & & & & $* 15$ & 9 & \\
\hline
\end{tabular}

${ }^{1}$ Announcement of operating band for the overnight rate. ${ }^{2}$ Since July 1995, explicit indications about the desired average level of the overnight rate. ${ }^{3}$ Following the introduction of the new monetary framework in the autumn of 1992, the Bank of England began to announce changes in official rates, applying in particular to the daily eligible bills variable rate tenders (stop rate). ${ }^{4}$ Weak signals via variable rate tenders with pre-announced quantities; speed of reserve accumulation (published daily) underlines the signal. ${ }^{5}$ Switch to fixed rate tenders to strengthen signals. ${ }^{6}$ In order to change the rate, the central bank either repeats the tender (if bids are inconsistent with the policy rate) or prepares the ground on previous days through finetuning operations. ${ }^{7}$ In particular, central rate. ${ }^{8}$ Rate on deactivated discount facility. ${ }^{9}$ Until the introduction of the new monetary framework, 2.30 lending: when instituted, this replaced the usual 2.45 p.m. lending facility, and was done at a longer maturity than overnight (typically one week), e.g. to reinforce prevailing rates against expectations of a cut. ${ }^{10}$ Cash setting (redeposit/drawdown). ${ }^{11}$ Published daily. ${ }^{12}$ Lombard credit; published daily. ${ }^{13}$ Signalling operations at 9.20 a.m., based on amounts supplied relative to the forecast of autonomous factors. ${ }^{14}$ Rarely. ${ }^{15}$ Long-term foreign exchange swaps when market rates are seen as too high. 
intention has been to give clear signals or to calibrate the pace of decline in market rates, as most recently. ${ }^{74}$ The central banks in Italy and Spain rely exclusively on variable rate tenders. In Italy, the comparatively weak guidance for market rates through tenders ${ }^{75}$ is supported by low-key quantitative signals (see below) and highly visible changes in the discount rate. By contrast, the Bank of Spain does not use either form of signal. In this case some technical difficulties may arise when the central bank wishes to change policy and participants are taken by surprise. ${ }^{76}$ The central bank either prepares the ground through fine-tuning operations conveying interest rate signals on previous days or simply calls for a second auction immediately after the first and in effect announces the minimum rate.

A potential drawback in using regular tenders to convey policy messages is that they cannot provide any direction in the periods between auctions when changes are needed. The issue is especially relevant for countries with exchange rate commitments, where reactions to market developments have to be immediate. In this case a possible solution is to rely on interest rates on standing facilities, which can be changed at any time. ${ }^{77,78}$ More generally, these rates can be used to reinforce or validate policy changes effected via tenders, especially where such signals may be less clear, as where variable rate tenders are employed. In certain countries, the practice of taking discount rates as a basis for setting administered bank loan rates reinforces their significance. By and large, however, with the increased prominence and visibility of tender rates and the practice of announcing operating targets, the role of standing facilities as signalling mechanisms has diminished.

Japan is the only country which nowadays arguably uses a quantitative signal as a key mechanism for steering an interest rate operating target, with the discount rate sometimes acting as an important reinforcing device. The central bank makes public its forecast of the net liquidity position of the system for the following day and announces the volume of operations for that day. Under normal conditions, the gap between the two would provide an idea of the degree of desired tightness or easing. ${ }^{79}$ Since March 1995, however, the central bank has been more transparent regarding desired levels of the overnight rate, announcing roughly the average rate that it would like to see in the market, with the discount rate continuing to perform a reinforcing role. ${ }^{80}$

74 When the Bundesbank wishes to give strong guidance to market rates, it may even announce in advance that the prevailing tender rate will also apply at the next auction.

75 In contrast to most other central banks relying on variable rate tenders, the Bank of Italy pre-announces the volumes to be auctioned. This could allow the central bank to provide a strong signal, by sharply cutting down on the percentage allocated below a specific (marginal) rate. This, however, is only very rarely done.

76 The situation was similar in the United Kingdom until the introduction of the new monetary framework following the departure from the ERM in September 1992. Analogous problems led to the practice of announcing a Minimum Lending Rate (MLR) for the day of the change in policy. This rate would then be taken by the market as the stop (marginal) rate for the new tender. The MLR has a purely symbolic character.

77 In Belgium, in fact, the situation is similar to that in the United kingdom. The rate on the weekly tender is itself equal to the central rate, which applies to a standing facility for loans and deposits granted by the central bank to primary dealers.

78 At the limit, if markets learn to anticipate perfectly the reactions of the central bank and policy is fully credible, the desired changes in market interest rates may be brought about automatically by participants. In many respects, this is the situation in the Netherlands, for instance, which has pursued an exchange rate peg with Germany for a long time. In more recent years such market-induced adjustments have also taken place in Belgium.

79 In contrast, the central bank monitors the pace of reserve accumulation relative to its reference path over the maintenance period (the "progress ratio") only to ensure orderly market conditions.

80 In March 1995 the Bank of Japan announced its intention to "calibrate" the decline of the overnight call rate to lower levels. In July 1995 it announced that it expected short-term money market rates to decline on average slightly below the discount rate (an overnight rate below the discount rate was unprecedented). Again, in September 1995, when the discount rate was further cut by $0.5 \%$, a similar announcement was made. 
Table 5.2

Disclosed information about market operations ${ }^{1}$

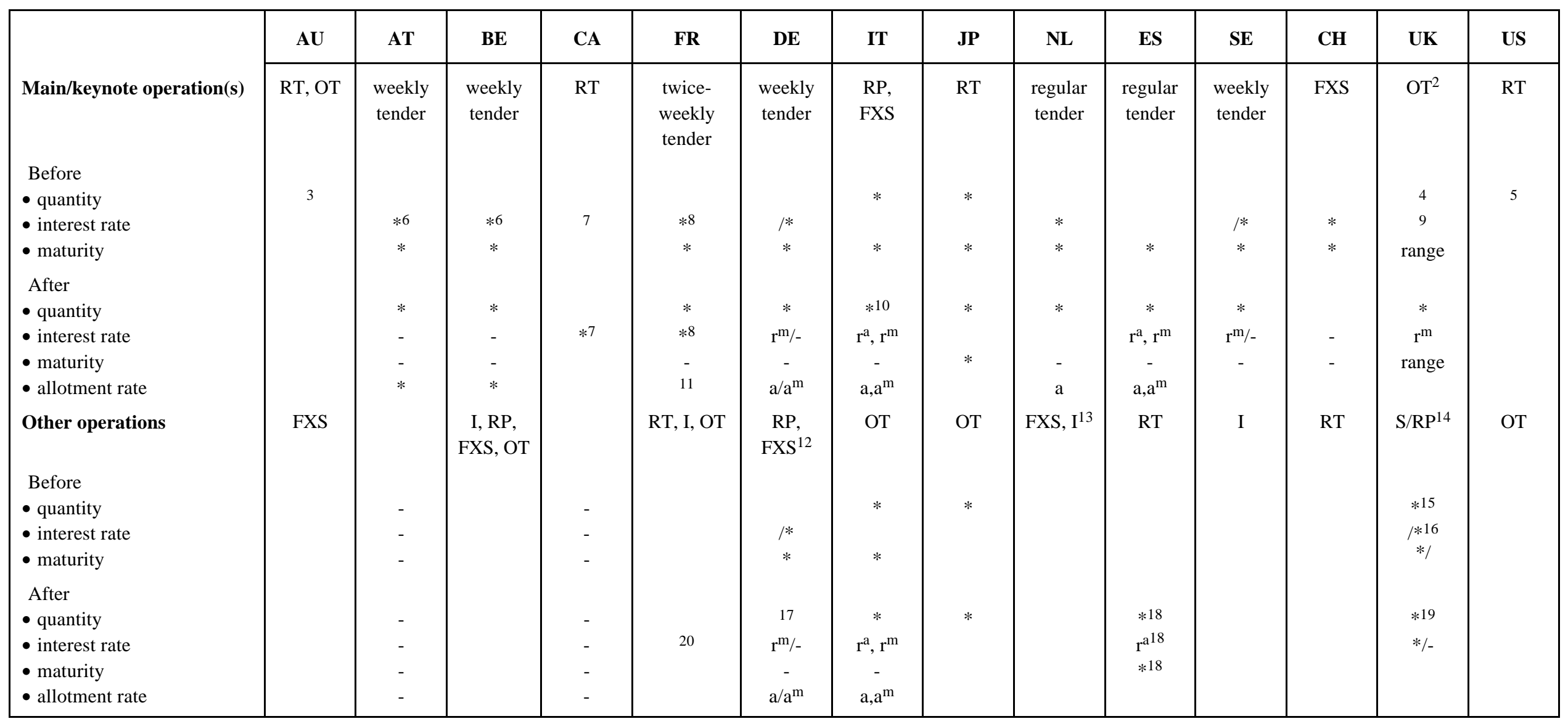

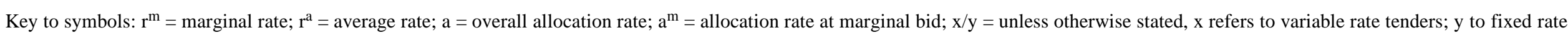
tenders.

Footnotes: See opposite. 


\section{Footnotes to Table 5.2}

${ }^{1}$ The table refers to the information regarding market operations made public before and after their completion. See also Table 4.6 for the list of operations. Transfers of government deposits are excluded. ${ }^{2}$ Purchases of eligible bills and complementary bill repos. Information regarding occasional Treasury bill sales is similar. ${ }^{3}$ The central bank does not announce the quantity but informs the market if it wants to buy or sell. ${ }^{4}$ Forecast of the size of the aggregate daily shortage (surplus for Treasury bill sales) announced. ${ }^{5}$ Approximate size of customer repos only. ${ }^{6}$ Variable rate tenders also possible, but hardly ever or as yet not employed. ${ }^{7}$ The intervention rate on SRAs and SPRAs has been announced since January 1996 (through a press release) when it involves changes in the operating band for the overnight rate. Before that, it was not announced but was disseminated quickly among partipants and picked up by news agencies. ${ }^{8}$ Preannounced in certain cases. ${ }^{9}$ De facto the minimum rate (maximum for Treasury bill sales) is known since the central bank announces changes in its official rate (Minimum Lending Rate). The rate is only occasionally tested by the market. ${ }^{10}$ Only rarely cut significantly relative to pre-announced volumes. ${ }^{11}$ Identical for each participant irrespective of the rate at which the bid is made. ${ }^{12}$ No information provided on reversed transactions against foreign exchange; the terms below refer to "quick tenders" only. ${ }^{13}$ In addition, sales of central bank certificates are conducted through variable rate tenders (Dutch allocation). The six-month maturity has been chosen to avoid giving any signals. ${ }^{14}$ Regular Treasury bill tenders and gilts repos respectively. ${ }^{15}$ Discount houses have a collective obligation to underwrite the Treasury bill tender at a rate of their own choosing, but the central bank has never called upon them to do so. ${ }^{16}$ Fixed rate tender at the official rate. ${ }^{17}$ Volumes published only after the end of the maintenance period. ${ }^{18}$ Aggregate information on daily fine-tuning operations made public only after market closing. ${ }^{19} \mathrm{Can}$ be cut in relation to pre-announced volumes. ${ }^{20}$ Information provided only if it is desired to give a signal. For instance, in August 1993 the central bank kept an "official" overnight repo rate, which it lowered only gradually.

A precondition for effective signalling is that actions not designed to have any policy significance should be clearly recognised as such. This is easier said than done: in principle any action taken by the central bank can reveal something about its policy intentions. After all, reading the tea-leaves in order to divine policy changes is a major source of potential profits for participants. This applies as much to speeches and pronouncements as to money market operations. Central bank officials are generally just as careful about what they say in public as they are in attempting to make clear the distinction between purely liquidity management (technical) operations and those designed to set the tone of policy.

There are a variety of ways of making this distinction clear. Present arrangements in the United States seem to be especially suitable: the Fed announces a target for an interest rate in one market (federal funds), operates in another as a price taker (the well-established private repo market) and hardly provides information about these operations. Difficulties may still arise, however, given the previous long tradition of conveying signals through market operations (see below). The main strategy elsewhere also generally relies on the same principles: giving little information about non-keynote operations, acting whenever possible as a price taker in the markets or else transacting at rates consistent with those established at the policy setting stage (Table 5.2). ${ }^{81}$

Distinguishing between policy setting and liquidity management transactions does not necessarily imply relying exclusively on one signalling mechanism. Most central banks find it useful to have a variety of possibilities at their disposal. Complementary signalling procedures can be particularly helpful in resisting undesired changes in market rates other than by just keeping the key policy rate constant: the markets may simply interpret this as a delay in policy action. Alternatively, they can be useful to "test the waters": that is, to explore whether the market reaction to a policy change is consistent with the central bank's objectives. This tactic is particularly relevant for countries with exchange rate commitments, when testing whether a policy easing would be tolerated by the markets without unpleasant implications for the external value of the currency. Finally, they may help to underline otherwise ambiguous signals.

81 In the Netherlands, one reason for issuing central bank certificates at a considerably longer maturity than that of periodic keynote tenders has been precisely to avoid the risk of having the market attach any policy significance to the issue rate. 
Some of these mechanisms operate by pacing the injection of liquidity into the system. Over and above any liquidity effect, the tactics work because participants are aware of what the central bank is doing and have come to understand its intentions. The Bank of England and the Bundesbank, for example, have used similar signals to those adopted by the Bank of Japan: they can bring forward or postpone the injection of liquidity into the system relative to the standard pattern. In the United Kingdom, this would be done within the day, by varying the volumes auctioned at the different times of the day in relation to the announced net liquidity forecast for that day; the end-of-day settlement needs, however, are always met in full and participants know that. ${ }^{82}$ In Germany, the Bundesbank can do the same over the maintenance period of the reserve requirement (front and back-loading). German banks can monitor the fulfilment of the requirement and the system's recourse to the lombard facility with a one-day lag. ${ }^{83}$ In Italy, the pace of reserve accumulation (also published each day by the central bank) helps to clarify the weak signals contained in tender rates. In Canada and Belgium, providing through regular operations more or less funds than required to balance the system at the end of the day performs a similar function to the procedure in Germany or the United Kingdom. Typically, there would be a lag of a couple of days until the policy is truly effective since, in contrast to the United Kingdom, the information set up is not as transparent. ${ }^{84}$ Once policy returns to neutral, the interest rates remain at their new level, a clear sign of signalling at work.

Other signalling tactics rely to different degrees on prices or maturities. Subtle changes in maturities can be used to resist market pressures on interest rates. The Swiss National Bank, for instance, offers swaps of an unusually long maturity (at market rates) when market rates are seen as too high. ${ }^{85}$ The Bank of England has in the past also followed a similar procedure, by on occasion tendering bills only at the longer maturity ranges. Making public the interest rates at which fine-tuning operations take place, when that is not otherwise done, is another possibility; the Bank of France has done so occasionally at times of exchange rate pressure. Sometimes the signal may be a combination of shifts in maturity and announcements of interest rates; 2.30 lending, discontinued since the announcement of changes in official rates, was a case in point in the United Kingdom. Finally, "open mouth" policy may be employed, providing direct guidance through speeches or public statements.

At the same time, relying on a number of signals raises issues regarding potential inconsistencies and hence interpretation problems. Difficulties of this kind have, for example, been encountered in Canada. Before the introduction of the operating band in 1994, the central bank steered

82 For example, in order to show resistance to signs of undesired pressure on interest rates, the Bank of England could leave the system "short" relative to the normal pattern of daily liquidity injection at the 9.45 a.m. tender. This tactic has not been used recently.

83 In comparison with the signal provided by the Bank of England, that of the Bundesbank is more ambiguous ("noisy"). The Bundesbank does not publish the forecast for the average reserve requirement, which becomes perfectly known only on or after the 20th of each month (around one week before the end of the maintenance period). Banks, therefore, make their own forecast. Inducing the system to borrow for some days from the lombard window can strengthen the signal's clarity.

84 In Canada the few large banks can quickly work out among themselves what the adjustment in liquidity has been; they may find it harder to calculate target settlement balances for the system as a whole. For that purpose they can use a highly publicised formula elaborated by the Bank of Canada which, on average, appears to track behaviour reasonably well. These "cash setting" operations by the Bank of Canada have been the main instrument for steering the overnight rate within the 50 basis point operating band. Given averaging provisions, the mechanism resembles in part that in place in the United Kingdom or Germany. A recent tactic has been to nudge the rate towards the bottom of the band and leave it there for a while to see whether the market is comfortable with the lower level, that is, whether there is no adverse reaction in money and exchange markets. If these remain stable, the central bank then feels free to lower the operating band. Market participants are fully aware of this tactic.

85 As noted by the central bank, news agencies and reporters usually hasten to find out whether signals were indeed intended. 
the overnight rate with a view to influencing the three-month Treasury bill rate, to which the Bank rate, the interest rate on end-of-day overdrafts, was then related through a mark-up. ${ }^{86}$ The choice of the three-month rate as operating target reflected the view, still prevailing today, that rates at that maturity played a key role in the transmission mechanism. ${ }^{87}$ The Treasury bill rate was also influenced through signals sent through outright operations in the secondary market. As a result of this set-up, it was on occasion difficult to distinguish whether, say, increases in the overnight rate effected through the redeposit/drawdown mechanism were designed to raise the three-month rate or simply to slow down the pace of its decline, two quite different policy stances. The noisy nature of the signal regarding the overnight rate itself further compounded the problem. The decision in early 1996 to set the Bank rate equal to the upper bound of the operating band was in part intended to avoid any residual confusion about operating objectives.

\subsection{Why does signalling work?}

It may be somewhat surprising that the core of policy setting is signalling. The earlier analysis would suggest that except in circumstances where liquidity operations are themselves used to send signals or to make marginal adjustments, policy implementation could conceptually be divided into two rather distinct parts. The first, liquidity management, prepares the ground for the setting of policy by neutralising distortions in short-term rates arising from working balance constraints. The second, signalling, influences the operating target. But how can mere announcements have such a critical effect? That they clearly do so is evident from the fact that in some cases policy signals are sent, and market rates change, without any liquidity operations ever taking place. The Swiss experience, for instance, is quite telling: the central bank uses a deactivated discount window facility to give guidance to interest rates.

The answer perhaps lies in the fact that as monopolist supplier of settlement balances, the central bank could, if it so wanted, set the overnight rate. It could do so by injecting/withdrawing the volume of settlement balances demanded by the market at the desired rate. ${ }^{88}$ And, through arbitrage, it could influence rates further along the money market yield curve for the period in which no further change was anticipated. The length of time and maturity, of course, would depend on the credibility of the central bank's policy.

This situation is in sharp, and possibly increasing, contrast with what occurs in the foreign exchange market. There, central banks have become progressively less able to maintain exchange rates at levels inconsistent with those seen as acceptable by the markets. The contrast may in part explain why the tendency in foreign exchange intervention in recent years has been, if anything, towards less, rather than greater, transparency: the threat behind the corresponding signal has become less credible. Intervention may have more impact if it is unclear to market participants whether the observed trading reflects a change in market sentiment or policy actions against the grain of expectations. It may also explain why the effectiveness of signalling per se for domestic monetary policy purposes is much reduced at times when exchange rate commitments are tested: it is then that the credibility of the policy stance is most severely questioned (Annex V).

86 Specifically, the Bank rate was set 25 basis points above the weekly auction rate.

87 The three-month rate is one of the two variables making up the Monetary Conditions Index (MCI), the other being the exchange rate. The MCI is the main variable guiding policy at the strategic level to achieve the inflation target.

88 As long as the exchange rate is allowed to float, technical constraints in the form of, for example, limited collateral are not an issue (Annexes V and VI). 


\subsection{Choice of maturities and volatility revisited}

The foregoing analysis helps to cast further light on the choice of the maturity of the operating target, on the relationship between this and the maturity of operations and on the acceptable degree of volatility in the target rate.

It is no doubt possible to justify differences in the maturity of operating targets across countries in terms of specificities of the structure and workings of national money markets. For example, in the United States one can draw attention to the extensive reliance on overnight financing and to the common practice of using the federal funds rate as benchmark for the pricing of loans ${ }^{89} \mathrm{At}$ the same time such differences are, at least in part, the markets' response to a policy choice. In other words, it is not just that a specific interest rate is chosen by the central bank because it is objectively important; also, once a rate is singled out as the operating target it becomes important. And it becomes so because it is seen as the variable that the central bank attempts to control and hence as a vital piece of information to anticipate its reactions. In Canada, for example, the banks' prime rate has tended to be particularly responsive to the rate targeted by the central bank. Accordingly, in recent years the link with the overnight rate has become stronger at the expense of that with the Treasury bill auction rate.

Similarly, it is equally debatable whether the tendency towards a shortening of the maturity of operating objectives is an entirely deliberate process. Central banks generally recognise that within the money market curve the key rates in the transmission of policy impulses are those at the three-month maturity or beyond. Admittedly, the retreat to shorter maturities is fully consistent with, if not demanded by, the heightened market orientation of policy. Moreover, it also allows the central bank to obtain more, or at least clearer, information about market participants' views and expectations. Nevertheless, that information is, fundamentally, only information about views of the central bank's future policy course, seen either as unfettered or under the pressure of events. It can therefore be useful in anticipating and assessing reactions, but ultimately is a reflection of the new constraints under which central banks are operating. In other words, the move to shorter maturities is probably just as much the result of a deliberate policy as of an inevitable process associated with the increased power of markets. Interest rates other than the overnight rate, which depends directly on the supply of settlement balances, are less and less controllable through market operations. The central bank does not have a monopoly over funds availability except in the market for settlement balances. Looking ahead, with the introduction and further development of real-time gross settlement, the shortening of the maturity focus may well not have come to an end (Annex VI).

These arguments also suggest that the link between the maturity of operations and that of the operating target is not as direct as might appear at first glance. Since it is generally not by supplying funds at a particular maturity that an interest rate is controlled, the two can be decided upon largely independently..$^{90}$ True, operating at the same maturity can help to underline policy signals, but otherwise is not strictly necessary. ${ }^{91}$ The maturity of market operations can thus be left to be decided primarily, if not exclusively, with a view to facilitating technical liquidity management, as is actually the case in most countries. ${ }^{92}$

89 Similarly, in the United Kingdom longer-term money market rates are targeted on the grounds that banks' base rates are very closely tied to them.

90 The main exceptions are standing facilities aimed at enforcing upper and lower bounds to the overnight rate. In this case, a watertight mechanism would call for identical maturities.

91 It could even be counterproductive if it gave the market the impression that the central bank was indeed trying to peg a longer-term money market rate by adjusting the supply at that maturity. Its effective power to do so could be subject to test.

92 This works as long as the market clearly recognises that the maturity of operations is not intended to have any signalling content. Otherwise, operating at, say, a ten-day maturity might be incorrectly interpreted as a signal that the policy rate would not be changed for that interval of time. 
Should volatility matter, and if so, why? That central banks do care about it is abundantly evident from their efforts to reduce it. From the viewpoint of the smooth operation of markets, volatility in short-term rates may be a problem on certain occasions, but it is difficult to judge what the tolerance level of the system may be. In any case, markets seem to have proved quite resilient in dealing with it, if not to have thrived on it. From the viewpoint of monetary policy, the key issue is the extent to which volatility in interest rates may unnecessarily cloud policy intentions, hindering the pass-through of intended policy changes or inducing market participants to see a change when none has actually occurred. It is, therefore, the volatility in the operating objective which is relevant.

The degree of volatility that can be tolerated in policy implementation arguably varies across countries, depending on the features and degree of understanding of signalling strategies. Beyond the technical effectiveness of specific signalling mechanisms, there is an inevitable trade-off between the wish to retain a certain ambiguity in signals and the risk of misinterpretation. Greater ambiguity can by itself generate greater volatility which, in turn, may increase the risk of misinterpretation. The sharp reduction in day-to-day volatility in the Australian overnight rate following the announcement of targets in 1990 and the greater speed with which market rates appear to respond to policy changes are a clear illustration of the potential gains from greater transparency. Whether the potential costs in terms of loss of flexibility and "cover" make such a strategy universally appropriate is much harder to say.

Similarly, announcements of interest rate targets may not be sufficient to pre-empt problems raised by volatility unless the practice is well established. In the United States, for example, protracted day-to-day departures of the federal funds rate from its target can still from time to time give rise to active speculation in the business press and among market watchers about possible unannounced policy changes. It is hard to judge, however, for how long such behaviour might persist and what its material impact on policy might be.

\section{Conclusions}

Current monetary policy implementation procedures can best be viewed from two complementary perspectives: as a set of instruments and practices aimed at equilibrating the supply of and demand for bank reserves ("liquidity management") and as a set of mechanisms for communicating the central bank's policy intentions and guiding market rates ("signalling"). At the root of this distinction is the wish to focus primarily on interest rates as operating objectives while at the same time to do so without fixing very short-term rates through standing facilities, in line with the preference for a market-oriented approach.

From the standpoint of liquidity management, the trends that best capture the strengthened market orientation of policy are the increased reliance on market operations at the expense of standing facilities - a trend generally dating back to the early 1980s - and the abandonment of residual direct controls. Nowadays, with very few exceptions, standing facilities serve primarily as safety valves and as guideposts reinforcing the communication of the medium-term policy stance. The bulk of liquidity management is effected through market operations.

Partly under pressure from increasingly mobile international capital and owing to the greater focus placed since the early 1980s on exchange rate objectives in several countries, central banks have considerably widened the range of instruments used in their market operations. Among these, reversed transactions, especially against domestic-currency-denominated assets, have become almost without exception the main policy tool. Their principal advantage is flexibility: they do not require a liquid underlying market to be effective and permit the decoupling of the maturity of the injection/withdrawal of liquidity from that of the asset temporarily transferred in the transaction. Mutatis mutandis, outright sales or purchases on secondary markets for securities generally still play a much more limited role. As regards the range of instruments employed by individual central banks, 
marked differences still exist. Some central banks rely on comparatively few types of operation, others make use of a much broader set of instruments.

Alongside the widening range of policy tools, liquidity management has become much more active: central banks have typically shortened the maturity of market operations, increased their frequency and complemented regular basic refinancing transactions with others taking place as required by changing circumstances. Here again, one factor behind this development in several countries has been the greater weight of exchange rate objectives or constraints. But, more generally, greater activism has been driven by the continuing trend reduction in reserve requirements, notably as a result of domestic and international competitive pressures. In its wake, the marginal demand for bank reserves has increasingly come to be determined by the need for settlement balances rather than by averaging provisions. Since, as a rule, the demand for working balances is highly insensitive to interest rates, central banks have had to be much more present in the market in order to avoid undesired sharp movements in the overnight rate. It is as if, given the peculiarities of the market for bank reserves, central banks could only choose how to be present, viz. through imposed stabilising reserve requirements, standing facilities or active market operations, but not the degree of involvement as long as their objective is defined in terms of an interest rate. If, for example, the Bundesbank can still rely on reserve requirements so as to operate in the market often only once a week, several central banks in systems where no requirements are in place have to do so typically more than once a day, notably the Bank of England.

In recent years central banks have further sharpened their focus on interest rates as operating objectives. The only country which in principle still targets bank reserves is Switzerland. Even so, this option has been pursued in a rather flexible manner and on occasion has had to be temporarily put aside, with greater attention being paid to interest rates in order to avoid the risk of throwing policy off course. The general focus on interest rates partly reflects their increasing role in the transmission mechanism in liberalised markets. But it also derives from the conviction that, even where monetary targets are still the fulcrum of policy strategy, a more quantitatively oriented approach in implementation would result in greater volatility in very short-term rates with no gains in terms of medium-term controllability of intermediate objectives.

The sharper focus on interest rates as operating targets has gone hand in hand with attempts to make policy signals clearer. Technically, the reason behind this is precisely the very low interest sensitivity of the demand for working balances and the importance of expectations about future very short-term interest rates where reserve requirements with averaging provisions are binding. These factors make signalling indispensable in order to achieve objectives for very short-term rates. More fundamentally, the process has been driven by broader changes in the political and economic environment, including the decline in inflation to comparatively low levels, a better political appreciation of the merits of keeping inflation low, the move towards greater independence and accountability of central banks and the much-increased influence of market forces and expectations in the formation of interest rates. On the whole, these elements have tended to shift the balance of perceived costs and benefits in favour of greater transparency. Nevertheless, the assessment of the value of increased openness is not universally shared, with some central banks, notably the Swiss National Bank and the Bank of Italy, fearing the loss of flexibility in adjusting interest rates that it may entail.

Alongside the primary signals regarding the basic interest rate objective, most central banks retain other supporting mechanisms. These can perform several functions, including communicating changes in policy when the main signals can only be sent at regular intervals (e.g. through fixed-schedule tenders), testing the market reaction to possible modifications in the policy stance, bringing about a change in the stance in a less obvious way and resisting or encouraging market-induced movements in interest rates. At the same time, these mechanisms appear 
to be less prominent or less actively used than in the past. ${ }^{93}$ This is partly the result of the shift towards greater transparency. ${ }^{94}$

On the whole, the maturity of the interest rates serving as the focus of policy implementation has tended to decline in recent years. In consequence, the overnight rate is now by far the most common operating target. Only a few countries covered in this study retain a focus on longer money market rates, notably the United Kingdom and the Netherlands. ${ }^{95}$ Elsewhere, the overnight rate is either perceived as the key policy rate and subject to explicit targets or else, under normal conditions, is not allowed to deviate much from the key policy rates signalled through regular tenders at somewhat longer maturities. Even where the overnight rate is not the focus, in recent years efforts have been made to reduce its volatility where this was considered excessive.

The shortening of the maturity focus in policy implementation is fully consistent with the strengthened market orientation and the wish to extract as much information as possible regarding market participants' expectations from money market interest rates. Arguably, however, it is also another sign of the growing power of market forces in determining asset prices and hence of the increasing constraints under which central banks operate. These, of course, are the very forces that make communication and persuasion, rather than diktat, the only means through which policy can be effective.

Looking ahead, potentially the main structural factors shaping policy implementation are likely to be changes in payment and settlement arrangements. In the immediate future the introduction of real-time gross settlement and tighter risk control mechanisms may well imply only comparatively minor modifications in procedures. These relate mainly to the need to provide intraday central bank credit and to the frequency and timing of operations. Even within such a short horizon, however, a question mark lies over the risk that limits to the availability and efficient redistribution of collateral may be tested at times when central banks need to defend exchange rate commitments: these limits could pose problems for central banks injecting liquidity into the system in order to sterilise outflows, an issue which already emerged during the ERM crisis of 1992. In the longer term, it is possible to envisage a situation in which the ability to settle transactions at any time during 24-hour cycles in the various currencies could effectively blur the clear-cut distinction between overnight and intraday central bank lending. This could call for a redefinition of key maturity intervals and implementation strategies. But this, at least for the moment, is futurology.

93 Moreover, as mechanisms based on the pace of adjustment in the supply of liquidity have become less common, the distinction between liquidity management and signalling has been sharpened.

94 For example, in Germany the recent shift towards fixed rate tenders has reduced the need for back and front-loading.

95 In Europe, other countries not covered here also pay comparatively little attention to the overnight rate, including Denmark and Finland. 


\section{Annex I: Sources and uses of bank reserves: some cross-country statistics}

Section 1 in the main text presented the stylised framework that generally underlies liquidity management by central banks, breaking down changes in bank reserves into those resulting from autonomous factors beyond the central bank's control and those deriving from central bank influences. It then went on to put forward a taxonomy of policy instruments. In neither case, however, were any actual figures provided. This annex partially fills that gap. It does so only partially because of certain shortcomings in data availability which prevent a proper assessment of the significance of individual factors and instruments.

\section{Basic sources and uses of bank reserves}

As examined in Section 4, the most important planning and implementation horizon of liquidity management is the single day. The reason is that the market for bank reserves must balance each day: the impact of autonomous sources of liquidity must be absorbed by inbuilt stabilisers, such as averaging provisions for reserve requirements, or offsetting policy action by the central bank, be it through standing facilities or discretionary operations. The great efforts devoted to forecasting daily influences on liquidity underscore this point.

Unfortunately, publicly available data on sources and uses of bank reserves generally refer to longer horizons, sometimes one week and more often one month. This limitation severely constrains any analysis: it clouds the variability of the various factors and hence their relative quantitative significance; it does not permit a correct examination of the offsetting role of various policy instruments, whose maturity or horizon of operation is normally much shorter; and, mutatis mutandis, it gives too much weight to permanent influences on liquidity. ${ }^{96}$ Bearing these limitations in mind, it is nevertheless useful to take a look at the available data within a common framework so as to form an idea of the orders of magnitude involved.

Table A.I.1 illustrates the size and variability of changes in bank reserves for the period 1992-95, measured at a monthly frequency, highlighting the role of net autonomous factors and of the net central bank position according to the breakdown described in Box 1. "Faute de mieux", all the figures are scaled by the stock of currency and bank reserves, a measure of the size of the central bank's balance sheet. ${ }^{97}$

A few points stand out. First, even considering average flows over periods as long as two years (1992-93 and 1994-95), the impact on liquidity of net autonomous factors often changes sign within countries. In this sense, the use of the expression "structural position" to refer to the overall effect of autonomous sources of bank reserves hardly seems appropriate. Only in a few cases has the qualitative impact been constant across the two periods: a sizable withdrawal of liquidity is apparent in Australia, Italy, Spain and the United States; an injection is evident in Austria and Sweden. Second, the monthly variability in the net autonomous position is generally several times the average monthly change; the only exception is the United States, where the monthly standard deviation is also the lowest internationally. This variability differs greatly across countries. It is especially high in Sweden, ${ }^{98}$ France, the United Kingdom and Spain and comparatively low in Austria, Belgium,

96 A very interesting and informative analysis of daily data for European Union countries can be found in Escrivá and Fagan (1996), "Empirical assessment of monetary policy instruments and procedures (MPIP) in EU countries", Staff Paper No. 2, European Monetary Institute, May.

97 It is difficult to think of an appropriate scaling factor for international comparisons. GDP, for instance, seems to be too remote from the issue at hand.

98 The figures for Sweden, however, should be treated with great caution owing to several discontinuities associated with changes in operating procedures, especially in 1994 
Germany and Switzerland. The relatively low figure for Germany, coupled with the reliance on averaging provisions for reserve requirements, is consistent with the limited use of fine-tuning operations. Third, measured at the monthly frequency changes in working balances/excess reserves are hardly noticeable, which explains why they are not singled out in the table. Finally, the very high standard deviation of bank reserves in the Netherlands is indicative of the active use of adjustments in reserve requirements as a means of offsetting the impact of autonomous sources of liquidity: ${ }^{99}$ indeed, the Netherlands is the only country for which this variability exceeds that of the net central bank position.

Table A.I.1

Basic sources and uses of bank reserves ${ }^{1}$

\begin{tabular}{|c|c|c|c|c|c|c|c|c|c|}
\hline & \multicolumn{2}{|c|}{$\begin{array}{c}\text { Net autonomous } \\
\text { position }\end{array}$} & \multicolumn{2}{|c|}{ Net policy position } & \multicolumn{2}{|c|}{ Bank reserves $^{2}$} & \multicolumn{3}{|c|}{ Memo: Standard deviation ${ }^{3}$} \\
\hline & $1992-93$ & $1994-95$ & $1992-93$ & $1994-95$ & $1992-93$ & $1994-95$ & $\begin{array}{c}\text { Net } \\
\text { autono- } \\
\text { mous } \\
\text { position }\end{array}$ & $\begin{array}{c}\text { Net } \\
\text { policy } \\
\text { position }\end{array}$ & $\begin{array}{c}\text { Bank } \\
\text { reserves }\end{array}$ \\
\hline & \multicolumn{9}{|c|}{ as a percentage of the average level of currency and bank reserves } \\
\hline Australia ............ & -1.33 & -2.22 & 1.44 & 2.35 & -0.10 & -0.13 & 8.1 & 8.0 & 0.5 \\
\hline Austria ................ & 0.44 & 0.28 & -0.43 & -0.35 & -0.01 & 0.07 & 2.9 & 3.1 & 0.8 \\
\hline Belgium .............. & -0.62 & 0.14 & 0.62 & -0.14 & 0.00 & 0.00 & 3.7 & 3.7 & 0.0 \\
\hline Canada ..................... & 0.79 & -1.46 & 0.06 & 1.42 & -0.85 & 0.04 & 4.7 & 3.4 & 1.9 \\
\hline France ................... & -4.11 & 4.06 & 3.30 & -4.04 & 0.81 & -0.02 & 30.4 & 31.0 & 2.7 \\
\hline Germany ............. & - 0.01 & - 0.45 & -0.15 & - 0.29 & 0.16 & 0.73 & 4.3 & 4.4 & 2.6 \\
\hline Italy ........................ & -1.53 & -0.73 & 1.04 & 0.03 & 0.49 & 0.71 & 6.1 & 6.4 & 2.8 \\
\hline Japan ...................... & 0.59 & -1.12 & - 0.71 & 1.17 & 0.11 & -0.05 & 7.3 & 7.5 & 0.9 \\
\hline Netherlands ........ & 1.87 & -1.06 & - 0.09 & -1.20 & - 1.78 & 2.26 & 9.7 & 2.3 & 9.7 \\
\hline 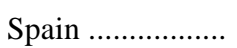 & -3.65 & -0.12 & 3.17 & 0.15 & 0.49 & -0.03 & 13.2 & 13.7 & 3.7 \\
\hline Sweden $^{4}$................. & 8.00 & 3.07 & -7.86 & -3.38 & -0.14 & 0.31 & 46.4 & 46.2 & 1.1 \\
\hline Switzerland ........ & -0.56 & 0.57 & 0.57 & -0.57 & -0.01 & 0.00 & 4.4 & 4.6 & 0.4 \\
\hline United Kingdom & -2.74 & 4.07 & 2.77 & -4.08 & -0.03 & 0.01 & 14.6 & 14.6 & 0.7 \\
\hline United States ..... & -0.72 & -0.55 & 0.75 & 0.46 & -0.03 & 0.09 & 0.8 & 1.0 & 0.4 \\
\hline
\end{tabular}

${ }^{1}$ Average monthly changes. In this and all following tables, $+=$ liquidity injection; $-=$ liquidity withdrawal. For a definition of the terms, see Box $1 .{ }^{2}$ Working balances/excess reserves are not shown separately because they are generally negligible. ${ }^{3}$ For the period $1992-95 .{ }^{4}$ Owing to changes in operating procedures, especially in 1994 , the series are not homogeneous.

Source: National data.

Table A.I.2 reports the breakdown of the net autonomous position into its main components, where available, viz., net foreign assets, net lending to the government, currency and other net assets (the residual). These figures should be interpreted with great caution, since the incidence of measurement problems, such as valuation effects, varies across components. ${ }^{100}$ Moreover, the influence of net foreign assets is especially difficult to measure correctly, sometimes because central banks are reluctant to reveal information about their exchange market intervention.

99 Of course, a much more useful measure would be the covariance of bank reserves with autonomous factors, measured at a higher frequency. In this case, the inbuilt stabiliser role of averaging provisions could be assessed. See Escrivá and Fagan, op. cit.

100 Often the flow figures are derived from changes in stocks. 
Table A.I.2

Breakdown of the net autonomous position ${ }^{1}$

\begin{tabular}{|c|c|c|c|c|c|c|c|c|c|c|c|c|}
\hline & \multicolumn{2}{|c|}{ Net foreign assets } & \multicolumn{2}{|c|}{$\begin{array}{c}\text { Net lending to } \\
\text { government }\end{array}$} & \multicolumn{2}{|c|}{ Other net assets } & \multicolumn{2}{|c|}{ Currency } & \multicolumn{4}{|c|}{ Memo: Standard deviation ${ }^{2}$} \\
\hline & $1992-93$ & 1994-95 & $1992-93$ & 1994-95 & 1992-93 & 1994-95 & 1992-93 & 1994-95 & $\begin{array}{c}\text { Net } \\
\text { foreign } \\
\text { assets }\end{array}$ & $\begin{array}{l}\text { Net lending } \\
\text { to } \\
\text { government }\end{array}$ & $\begin{array}{c}\text { Other net } \\
\text { assets }\end{array}$ & Currency \\
\hline & \multicolumn{12}{|c|}{ as a percentage of the average level of currency and bank reserves } \\
\hline Australia ................. & -0.83 & 0.90 & 7.07 & 5.98 & -7.15 & -8.62 & -0.44 & -0.48 & 3.6 & 7.6 & 7.6 & 2.2 \\
\hline Austria .................... & 1.13 & 0.71 & 0.03 & -0.01 & -0.36 & -0.10 & -0.37 & -0.31 & 2.6 & 0.1 & 1.2 & 1.7 \\
\hline Belgium ................... & $-0.53^{3}$ & $0.18^{3}$ & -0.01 & 0.01 & 0.01 & 0.06 & -0.08 & -0.10 & 3.0 & 0.7 & 0.6 & 2.5 \\
\hline Canada ...................... & -0.82 & 0.54 & 9.52 & -0.33 & -7.45 & -1.44 & -0.46 & -0.23 & 5.5 & 9.0 & 6.7 & 3.9 \\
\hline France ...................... & -1.90 & 1.77 & -1.65 & 2.02 & -0.61 & 0.37 & 0.04 & -0.11 & 20.0 & 19.1 & 4.4 & 2.8 \\
\hline Germany ................... & 0.71 & 0.24 & 0.09 & 0.10 & -0.24 & -0.42 & -0.58 & -0.36 & 4.1 & 1.5 & 1.5 & 1.3 \\
\hline 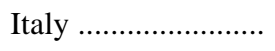 & -0.91 & -0.01 & -0.02 & -0.34 & -0.32 & -0.17 & -0.27 & -0.22 & 3.0 & 7.3 & 0.8 & 1.6 \\
\hline Japan ......................... & 0.21 & 0.70 & 0.57 & -1.36 & - & - & -0.19 & -0.47 & 1.0 & 6.3 & - & 6.8 \\
\hline Netherlands .............. & 2.60 & -0.18 & -0.88 & -1.50 & 0.19 & 0.70 & -0.04 & -0.07 & 6.9 & 8.9 & 2.1 & 1.0 \\
\hline Spain ........................ & -0.34 & -0.85 & -1.88 & 0.90 & -0.92 & 0.38 & -0.51 & -0.55 & 4.4 & 8.1 & 10.0 & 1.9 \\
\hline Sweden $^{4}$................... & 3.93 & -0.22 & 3.91 & 1.27 & 0.13 & 2.07 & 0.02 & -0.05 & 21.3 & 40.3 & 11.1 & 3.9 \\
\hline Switzerland ............... & 0.84 & 0.49 & -0.38 & 0.15 & -0.94 & 0.02 & -0.07 & -0.08 & 1.8 & 4.1 & 4.1 & 2.2 \\
\hline United Kingdom .... & -1.22 & -0.09 & -2.39 & 5.46 & 1.53 & -0.74 & -0.66 & -0.56 & 6.3 & 14.9 & 8.9 & 5.8 \\
\hline United States .......... & -0.08 & 0.01 & 0.03 & 0.02 & 0.01 & -0.01 & -0.68 & -0.57 & 0.2 & 0.5 & 0.2 & 0.5 \\
\hline
\end{tabular}

${ }^{1}$ Average monthly changes. For a definition of the terms, see Box $1 .{ }^{2}$ For the period 1992-95. ${ }^{3}$ Including foreign exchange swaps used to adjust domestic liquidity. ${ }^{4}$ Owing to changes in operating procedures, especially in 1994 , the series are not homogeneous.

Source: National data. 
The table indicates that in practically all countries currency tends to absorb liquidity, as it increases over time. This is in fact the key item behind the persistent net autonomous deficits identified in the previous analysis in Australia, Italy, Spain and the United States. In contrast, the qualitative impact of the other items typically varies considerably both across countries and over time. As regards the monthly variability of the autonomous sources of bank reserves, the evidence suggests that net lending to the government is the most volatile component in a majority of cases. Its standard deviation is especially high in France, the United Kingdom and, to a lesser extent, the Netherlands and Spain. The influence of net foreign assets is comparatively high in some of the economies with strong exchange rate commitments, including several ERM participants. Currency rivals net lending to the government as the most volatile item in the United States and Japan.

\section{Central bank influences}

It is for measuring the comparative quantitative significance of policy instruments that the shortcomings of available data are most acute. The main reason is that the maturity of some of the most actively used operations, such as repos, generally falls well short of one month (see Section 4): operations of an opposite sign cancel out and the need to renew the transactions cannot be captured. Using averages of outstanding stocks during a (calendar) month would alleviate some of these problems, but was possible on a consistent basis only in a few cases. Using the standard deviation of flows at a monthly frequency, as in the previous analysis, can only tackle offsetting changes between months. Thus, unless the maturity of the operations is similar, the data below are more indicative of the extent to which instruments are used to offset changes in liquidity over longer-term horizons than of their deployment in daily liquidity management.

Table A.I. 3

Breakdown of the net policy position: standing facilities and discretionary (market) operations ${ }^{1}$

\begin{tabular}{|c|c|c|c|c|c|c|}
\hline & \multicolumn{2}{|c|}{ Standing facilities } & \multicolumn{2}{|c|}{ Discretionary operations } & \multicolumn{2}{|c|}{$\begin{array}{c}\text { Memo: Standard } \\
\text { deviation }^{2}\end{array}$} \\
\hline & $1992-93$ & 1994-95 & $1992-93$ & 1994-95 & $\begin{array}{l}\text { Standing } \\
\text { facilities }\end{array}$ & $\begin{array}{c}\text { Discretionary } \\
\text { operations }\end{array}$ \\
\hline & \multicolumn{6}{|c|}{ as a percentage of the average level of currency and bank reserves } \\
\hline Australia ............................ & 2.49 & 3.81 & 2.62 & 4.56 & 9.0 & 5.3 \\
\hline 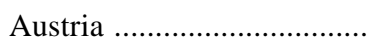 & - 0.43 & -0.38 & 0.00 & 0.03 & 3.1 & 0.1 \\
\hline Belgium .............................. & - 0.08 & -0.05 & 0.70 & -0.10 & 1.9 & 4.2 \\
\hline 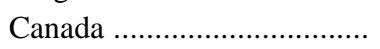 & - & - & 0.06 & 1.42 & - & 3.4 \\
\hline 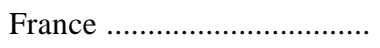 &..$^{3}$ &.$^{3}$ & 3.30 & -4.05 & .. & 30.1 \\
\hline Germany & $-\quad 0.27$ & 0.04 & 0.13 & -0.33 & 0.8 & 4.2 \\
\hline Italy & $-0.13^{4}$ & $0.11^{4}$ & 1.17 & - 0.08 & $2.2^{4}$ & 6.5 \\
\hline Japan & $0.00^{5}$ & $-0.01^{5}$ & - $\quad 0.71$ & 1.18 & $0.1^{5}$ & 7.5 \\
\hline 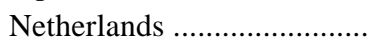 & -0.03 & -0.04 & -0.06 & $-\quad 1.16$ & 0.9 & 2.3 \\
\hline Spain & - & - & 3.17 & 0.15 & - & 9.8 \\
\hline 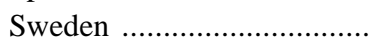 &.. &.. & $-7.86^{6}$ & $-3.38^{6}$ & .. & $46.2^{6}$ \\
\hline 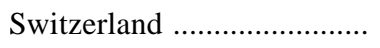 & -0.09 & 0.00 & 0.65 & $-\quad 0.57$ & 0.6 & 4.8 \\
\hline United Kingdom . ................. & 0.07 & - 0.06 & 2.70 & -4.02 & 1.4 & 14.4 \\
\hline United States ........................ & 0.00 & 0.00 & 0.75 & 0.46 & 0.0 & 1.0 \\
\hline
\end{tabular}

${ }^{1}$ Average monthly changes. See Box 2 for a definition of the terms and Section 4 for the transactions included. ${ }^{2}$ For the period 1992-95. ${ }^{3}$ Not available but very small. ${ }^{4}$ Distorted by highly erratic end-of-year movements. ${ }^{5}$ Fully discretionary discount window lending. ${ }^{6}$ Including the use of standing facilities (frequent but very small since at least 1995). Owing to changes in operating procedures, especially in 1994, the series are not homogeneous.

Source: National data. 
Despite these shortcomings, the available statistics do generally confirm central banks' greater and increasing reliance on discretionary, largely market, operations in comparison with standing facilities (Table A.I.3). ${ }^{101}$ As measured by the standard deviation in monthly flows, the quantitative significance of market operations is almost universally considerably higher than that of standing facilities. The only exceptions are Austria and Australia. In the case of Australia this results from classifying the zero-cost central bank float associated with the ability of certain participants to choose the settlement date ( $\mathrm{T}$ or $\mathrm{T}+1)$ as a (below-market) implicit standing facility; in that of Austria, it reflects the practice that has slowly been changing since the introduction of regular tenders in late 1995. A significant use of standing facilities is also noticeable in the Netherlands and Belgium. ${ }^{102}$ Since by far the quantitatively more important facilities are for injecting liquidity, the cumulative net withdrawal of liquidity discernible in several countries since 1992 is at least in part a reflection of steps to reduce their structural significance, including through cuts in available quotas. This is confirmed by the breakdown of standing facilities by type, which highlights the net repayment of credit granted at below market rates (Table A.I.4). ${ }^{103}$ The same table reveals the great reluctance of banks in the United States to turn to the discount window.

Table A.I.4

Breakdown of the net policy position: standing facilities ${ }^{1}$

\begin{tabular}{|c|c|c|c|c|c|c|c|c|c|}
\hline & & & \multirow{2}{*}{\multicolumn{2}{|c|}{ Market floor }} & \multirow{2}{*}{\multicolumn{2}{|c|}{ Below market }} & \multicolumn{3}{|c|}{ Memo: Standard deviation ${ }^{2}$} \\
\hline & \multicolumn{2}{|c|}{ Market ceiling } & & & & & Market & Market & Below \\
\hline & $1992-93$ & 1994-95 & $1992-93$ & 1994-95 & \multicolumn{2}{|c|}{\begin{tabular}{l|l}
$1992-93$ & $1994-95$ \\
\end{tabular}} & \multicolumn{3}{|c|}{$1992-95$} \\
\hline & \multicolumn{9}{|c|}{ as a percentage of the average level of currency and bank reserves } \\
\hline Australia ........... & 0.24 & 0.02 & - & - & 2.25 & 3.79 & 0.4 & - & 9.1 \\
\hline Austria .............. & 0.00 & 0.00 & 0.00 & 0.00 & -0.18 & -0.05 & 0.0 & 0.9 & 0.4 \\
\hline Belgium ............ & 0.00 & -0.01 & 0.02 & 0.02 & -0.06 & -0.02 & 1.6 & 0.6 & 0.2 \\
\hline France ................. &..$^{3}$ &..$^{3}$ & - & - & - & - &..$^{3}$ & - & - \\
\hline Germany ............... & 0.00 & 0.00 & - & - & -0.27 & 0.05 & 0.3 & - & 0.8 \\
\hline Italy ..................... & $-0.13^{4}$ & $0.10^{4}$ & - & - & 0.00 & 0.01 & $2.2^{4}$ & - & 0.1 \\
\hline Japan ................... & - & - & - & - & $0.00^{5}$ & $-0.01^{5}$ & - & - & $0.1^{5}$ \\
\hline Netherlands ...... & - & - & - & - & -0.03 & -0.04 & - & - & 0.9 \\
\hline Spain ….................. & - & - & - & - & - & - & - & - & - \\
\hline Sweden ................. &.. &..$^{6}$ & .. &..$^{6}$ & - & - &..$^{6}$ &..$^{6}$ & - \\
\hline Switzerland ....... & -0.01 & 0.00 & - & - & -0.07 & 0.00 & 0.6 & - & 0.1 \\
\hline United Kingdom & 0.07 & 0.06 & - & - & - & - & 1.4 & - & - \\
\hline United States ... & - & - & - & - & 0.00 & 0.00 & - & - & 0.0 \\
\hline
\end{tabular}

${ }^{1}$ Average monthly changes. For the facilities included, see corresponding tables in Section $4 .{ }^{2}$ For the period 1992-95. ${ }^{3}$ Not available but very small. ${ }^{4}$ Distorted by highly erratic end-of-year movements. ${ }^{5}$ Fully discretionary. ${ }^{6}$ Frequent but quantitatively very limited use of standing facilities since at least 1995.

Source: National data.

The classification of market operations by type tends to confirm the key role played by reversed transactions against domestic-currency-denominated assets, even when measured at the monthly frequency through changes in outstanding stocks (Table A.I.5). This is best shown by the comparatively high standard deviation of monthly changes in relation to those of outright transactions

${ }^{101}$ For present purposes, the analysis follows the classification given in Section 4. Standing facilities, therefore, include certain operations where a considerable degree of discretion is actually retained.

102 The figures for Italy are not representative of average behaviour.

103 In order to display the figures on a comparable basis, actual credit through the discount facility in Germany is reported, not the (discretionary) change in discount quotas. These were reduced throughout the period shown. 
in securities and of other operations. The main exception not arising from shortcomings in the available data is Switzerland, where foreign exchange swaps are the principal instrument.

Table A.I.5

Breakdown of the net policy position: discretionary (market) operations ${ }^{1}$

\begin{tabular}{|c|c|c|c|c|c|c|c|c|c|}
\hline & \multicolumn{2}{|c|}{$\begin{array}{c}\text { Outright } \\
\text { transactions in } \\
\text { securities } \\
\end{array}$} & \multicolumn{2}{|c|}{$\begin{array}{c}\text { Repo transactions } \\
\text { against domestic } \\
\text { currency }\end{array}$} & \multicolumn{2}{|c|}{$\begin{array}{c}\text { Other } \\
\text { transactions }^{2}\end{array}$} & \multicolumn{3}{|c|}{ Memo: Standard deviation ${ }^{2}$} \\
\hline & $1992-93$ & 1994-95 & $1992-93$ & 1994-95 & $1992-93$ & 1994-95 & $\begin{array}{l}\text { Outright } \\
\text { trans- } \\
\text { actions in } \\
\text { securities }\end{array}$ & $\begin{array}{c}\text { Repo } \\
\text { trans- } \\
\text { actions } \\
\text { against } \\
\text { domestic } \\
\text { currency }\end{array}$ & $\begin{array}{l}\text { Other } \\
\text { trans- } \\
\text { actions }^{2}\end{array}$ \\
\hline & \multicolumn{9}{|c|}{ as a percentage of the average level of currency and bank reserves } \\
\hline Australia ........... & 2.42 & 4.27 & 0.20 & 0.29 & - & - & 3.8 & 5.3 & - \\
\hline Austria .............. & - & - & -0.25 & -0.30 & 0.00 & 0.00 & - & 2.7 & 0.9 \\
\hline Belgium ............ & 0.14 & -0.08 & 0.57 & 0.01 & - $0.01^{4}$ & $-0.02^{4}$ & 1.1 & 3.7 & 0.8 \\
\hline Canada ................. &.. &.. & 0.00 & 0.00 & 0.06 & 1.42 &.. & 2.8 & 4.3 \\
\hline France ................... & 0.25 & 0.10 & 3.55 & -3.95 & 0.00 & 0.00 & 1.9 & 30.3 & 0.0 \\
\hline Germany .............. & -0.35 & 0.33 & 0.45 & -0.61 & 0.03 & -0.05 & 1.2 & 4.2 & 1.2 \\
\hline Italy ..................... &.. & .. & 0.46 & -0.26 & 0.70 & 0.17 &.. & 6.2 & 1.6 \\
\hline Japan ................... & 0.26 & 0.66 & - 0.51 & 0.88 & 0.00 & 0.00 & 4.0 & 5.8 & 2.7 \\
\hline Netherlands ....... & - & - & -0.06 & 0.02 & 0.00 & -1.18 & - & 2.0 & 1.1 \\
\hline Spain ................... & - & - & 3.13 & 0.06 & - & - & - & 9.8 & - \\
\hline Switzerland ....... & - & - & 0.13 & 0.02 & 0.52 & -0.59 & - & 1.8 & 4.2 \\
\hline United Kingdom & 0.80 & -1.51 & 0.83 & -0.02 & 1.07 & -2.49 & 9.6 & 5.6 & 5.3 \\
\hline United States ... & 0.76 & 0.44 & -0.01 & 0.02 & - & - & 0.7 & 0.5 & - \\
\hline
\end{tabular}

${ }^{1}$ Average monthly changes. See Box 2 and the corresponding tables in Section 4 for the transactions included. Transfers of government deposits are not excluded, although they are not normally considered to be "market" operations. Sweden is excluded owing to major breaks in the series. ${ }^{2}$ Including, inter alia, FX swaps, issues of central bank paper (or of government paper on its behalf), transactions in the interbank market and transfers of government deposits. ${ }^{3}$ For the period 1992-95. ${ }^{4}$ Excluding foreign exchange swaps, for which no data are available.

Source: National data.

The fact that in a number of countries the average monthly flows connected with outright transactions are close to, if not higher than, those associated with repos is mainly a reflection of their longer maturity and their specific use, viz. as instruments typically designed to meet "longer-term" liquidity needs rather than to offset short-term fluctuations in those needs. This is most obviously the case in the United States, where the actual contribution of repos to changes in liquidity is very low, but it applies more generally. Detailed statistics on the daily impact on liquidity by type in Australia provide a vivid illustration of the extent to which the measurement technique employed can underestimate the extent to which short-maturity instruments are used to adjust the volume of bank reserves. Measured in terms of the gross amount of the operations, but without taking into consideration the maturity leg of the transactions, repos would account for over $90 \%$ of changes in liquidity, the remainder being associated with outright purchases/sales of Treasury notes. This figure is much higher than would be assumed on the basis of average monthly flows or their standard deviation (see the table). 


\section{Annex II: Reserve requirements: additional information}

\section{Box 4 \\ Institutions subject to reserve requirements ${ }^{1}$}

Australia: Banks and industry organisations representing building societies and credit unions (known as "Special Service Providers").

Austria: Generally, all domestic credit institutions.

France: $\quad$ All credit institutions except the Caisse Française de Développement. Also exception for very small-sized institutions.

Germany: With few exceptions, all institutions doing banking business (broadly defined). ${ }^{2}$

Italy: $\quad$ All credit institutions except very small ones.

Japan: City banks, regional banks, regional banks II, trust banks, long-term credit banks, branches of foreign banks, shinkin banks and Norinchukin Bank.

Netherlands: All credit institutions with very few exceptions. ${ }^{3}$

Spain: $\quad$ All credit institutions.

Switzerland: All banks.

United Kingdom: All authorised banks except very small ones.

United States: Commercial and savings banks, credit unions, foreign bank branches and agencies, Edge Act corporations.

1 In Canada, the requirement to maintain a non-negative settlement balance with the central bank on average during monthly periods applies to direct clearers only.

2 See Section 1(1) and Section 53(1) of the Banking Act.

3 All institutions must be entered in the register under Section 52 of the Act on Supervision of the Credit System. There are four exceptions because their liabilities are almost exclusively long-term. 
Table A.II.1

Reserve requirements: eligible liabilities and ratios

\begin{tabular}{|c|c|c|c|c|c|c|c|c|c|c|c|}
\hline & $\mathbf{A U}$ & $\mathbf{A T}$ & FR & DE & IT & $\mathbf{J P}$ & $\mathbf{N L}^{1}$ & ES & $\mathbf{C H}$ & UK & US \\
\hline $\begin{array}{l}\text { Non-residents } \\
\text { - domestic currency } \\
\text { - foreign currency } \\
\text { - netting } \\
\text { - banks } \\
\text { - only affiliated } \\
\text { - netting } \\
\text { Residents } \\
\text { - foreign currency } \\
\text { - banks } \\
\text { - netting } \\
\text { Type (ratios in \%) } \\
\text { - transaction \& sight } \\
\text { - time/savings } \\
\text { - certificates of deposit } \\
\text { - repos } \\
\text { - other } \\
\text { Other restrictions } \\
\text { - maturity } \\
\text { - volume } \\
\text { - other } \\
\text { Basis calculation } \\
\text { - level } \\
\text { - change }\end{array}$ & $\begin{array}{l}1.0 \\
1.0 \\
1.0 \\
1.0 \\
1.0\end{array}$ & $\begin{array}{l}5.0 \\
3.0 \\
3.0 \\
3.0^{10} \\
* 10\end{array}$ & $\begin{array}{c}* 4 \\
5 \\
\\
\\
1.0 \\
0.5 / 1.0^{8} \\
0.5 \\
0.5 \\
0.5^{11} \\
\\
<2 \mathrm{y} \\
* 8\end{array}$ & $\begin{array}{c}* \\
* \\
* \\
* \\
* 3 \\
\\
* \\
5 \\
\\
2.0^{6} \\
2.0 / 1.5 \\
2.0 \\
2.0\end{array}$ & $\begin{array}{l}15.0 \\
15.0 \\
15.0\end{array}$ & $\begin{array}{c}0.2-0.25 \\
0-1.8 \\
\\
0-1.3^{7} \\
0-1.2^{7} \\
0-1.8^{7} \\
0.1-0.15\end{array}$ & $\begin{array}{c}\text { variable } \\
\text { variable } \\
\text { variable } \\
\text { variable } \\
\text { variable } \\
13 \\
* 13\end{array}$ & $\begin{array}{l}2.0 \\
2.0 \\
2.0 \\
2.0^{12} \\
*\end{array}$ & $\begin{array}{l}2.5 \\
2.5^{9} \\
* \\
\end{array}$ & $\begin{array}{l}* \\
* \\
* \\
* \\
* 3\end{array}$ & $0.0-10.0^{7}$ \\
\hline
\end{tabular}

${ }^{1}$ The same criteria apply to the definition of eligible liabilities for the quota scheme. ${ }^{2}$ Deposits by branches of Italian banks with the parent, in order to avoid circumvention. ${ }^{3}$ As part of the netting of foreign currency positions. ${ }^{4}$ In principle included, but subject to a zero reserve ratio. ${ }^{5}$ Exempt as are other institutions subject to reserve requirements. ${ }^{6}$ Sight deposits defined as less than one-month maturity. ${ }^{7}$ The ratio varies with the size of the corresponding liability category. ${ }^{8}$ Passbook accounts. Various types of savings deposit are exempt. ${ }^{9}$ Only $20 \%$ of various forms of savings deposit. ${ }^{10}$ Bank-issued domestic-currency-denominated securities with less than a two-year maturity (zero rate on longer maturities). ${ }^{11}$ Off-balance-sheet liabilities. ${ }^{12}$ Some off-balance-sheet items, including guarantees backing commercial paper and endorsed bills. ${ }^{13}$ Most domestic-currency-denominated liabilities plus any foreign currency liability. The overall base is defined as domestic short-term liabilities plus $25 \%$ of all other liabilities. Variable ratios depending on the size of eligible liabilities and changing over time. ${ }^{14}$ Less than three-month maturity for time deposits and gross interbank liabilities. ${ }^{15}$ Certain detailed exemptions. 
Annex III: Standing facilities: additional information

Table A.III.1

Standing facilities: additional information

\begin{tabular}{|c|c|c|c|c|c|c|c|}
\hline & \multirow[t]{2}{*}{ Type } & \multirow[t]{2}{*}{ Name } & \multirow[t]{2}{*}{ Technical form } & \multicolumn{2}{|c|}{ Counterparties } & \multicolumn{2}{|c|}{$\begin{array}{l}\text { Underlying } \\
\text { instrument/ } \\
\text { collateral }\end{array}$} \\
\hline & & & & Banks & Other & Public & Private \\
\hline $\mathrm{AU}$ & $\begin{array}{l}\mathrm{MC} \\
\mathrm{MF}\end{array}$ & $\begin{array}{l}\text { Rediscount facility } \\
\text { Interest-bearing balances }\end{array}$ & $\begin{array}{l}\text { Rediscount } \\
\text { Deposit }\end{array}$ & * & $* 1$ & $\begin{array}{c}* 2 \\
-\end{array}$ & - \\
\hline AT & $\begin{array}{l}\mathrm{MC}^{3} \\
\mathrm{MF} \\
\mathrm{BM}\end{array}$ & $\begin{array}{l}\text { Lombard }^{3} \\
\text { REGOM } \\
\text { Discount facility }\end{array}$ & $\begin{array}{l}\text { Fixed-term loan } \\
\text { Deposit } \\
\text { Rediscount }\end{array}$ & $\begin{array}{l}* 4 \\
* 4 \\
* 4\end{array}$ & & $\begin{array}{l}* \\
- \\
5\end{array}$ & $\begin{array}{l}* \\
- \\
* 5\end{array}$ \\
\hline $\mathrm{BE}$ & $\begin{array}{l}\text { MC } \\
\text { MF } \\
\text { BM }\end{array}$ & $\begin{array}{l}\text { Ordinary/hors plafond advances } \\
\text { Deposit facility } \\
\text { Discount facility }\end{array}$ & $\begin{array}{l}\text { Fixed-term loan } \\
\text { Deposit } \\
\text { RP }\end{array}$ & $\begin{array}{l}* \\
* \\
*\end{array}$ & $\begin{array}{l}6 \\
6 \\
6\end{array}$ & $*$ & * \\
\hline $\mathrm{CA}$ & MC & Advances & Fixed-term loan & $* 8$ & $* 8$ & $*$ & \\
\hline FR & MC & 5 to 10 -day repurchases & $\mathrm{RP}$ & $*$ & & $* 9$ & $* 9$ \\
\hline $\mathrm{DE}$ & $\begin{array}{l}\mathrm{MC} \\
\mathrm{BM}\end{array}$ & $\begin{array}{l}\text { Lombard } \\
\text { Discount facility }\end{array}$ & $\begin{array}{l}\text { Fixed-term loan } \\
\text { Rediscount }\end{array}$ & $\begin{array}{r}* 10 \\
* 10\end{array}$ & & $*$ & $* 11$ \\
\hline IT & $\begin{array}{l}\mathrm{MC} \\
\mathrm{BM}\end{array}$ & $\begin{array}{l}\text { Fixed-term advances } \\
\text { Discount facility }{ }^{1}\end{array}$ & $\begin{array}{l}\text { Fixed-term loan } \\
\text { Rediscount }\end{array}$ & * & & $\begin{array}{l}* 12 \\
* 12\end{array}$ & $\begin{array}{l}* 12 \\
* 12\end{array}$ \\
\hline JP & $\mathrm{BM}$ & Discount window & Rediscount/fixed-term loan & $* 13$ & $* 13$ & $*$ & $* 14$ \\
\hline NL & $\mathrm{BM}$ & Advances (quota scheme) & C/A advance & $*$ & & $*$ & $* 15$ \\
\hline SE & $\begin{array}{l}\mathrm{MC} \\
\mathrm{MF}\end{array}$ & $\begin{array}{l}\text { Lending facility } \\
\text { Deposit facility }\end{array}$ & $\begin{array}{l}\text { Fixed-term loan } \\
\text { Deposit }\end{array}$ & * & $\begin{array}{l}* 16 \\
* 16\end{array}$ & $*$ & $* 17$ \\
\hline $\mathrm{CH}$ & $\mathrm{MC}$ & Lombard & Fixed-term loan & $*$ & & $*$ & $* 18$ \\
\hline UK & $\begin{array}{l}\mathrm{MC}(1) \\
\mathrm{MC}(2)\end{array}$ & $\begin{array}{l}\text { Late lending }{ }^{19} \\
\text { Clearing banks' facility }\end{array}$ & $\begin{array}{l}\text { Fixed-term loan } \\
\text { Outright purchase }\end{array}$ & $* 21$ & $* 20$ & $*$ & $*$ \\
\hline US & $\mathrm{BM}$ & Discount window & Rediscount/fixed-term loan & $*$ & & $*$ & $*$ \\
\hline
\end{tabular}

Key to symbols: $\mathrm{MC}=$ market ceiling; $\mathrm{MF}=$ market floor; $\mathrm{BM}=$ below market.

${ }^{1}$ Any registered holder of Treasury notes. ${ }^{2}$ Treasury notes. ${ }^{3}$ For GOMEX, identical counterparties and collateral. ${ }^{4}$ All domestic banks subject to reserve requirements. ${ }^{5}$ Bills of exchange (promissory notes resulting from merchandise transactions) in local currency and issued by domestic firms, at least two signatures; possible for public firms if managed separately from the public administration. ${ }^{6}$ In principle, certain institutions participating in the securities settlement system are also eligible. ${ }^{7}$ Bills of exchange. ${ }^{8}$ See Table A.IV.1 on the standing facility available to investment dealerjobbers (PRAs) that takes the form of reversed transactions against government securities. ${ }^{9}$ Treasury bills or grade 3 rated bills. ${ }^{10}$ All credit institutions that maintain an account at the central bank (lombard) and doing bills business (rediscount facility, which excludes mortgage banks). ${ }^{11}$ Bills of exchange, backed by three solvent parties; including issues by the federal government, one of the federal special funds or a Land Government. ${ }^{12}$ Bank bonds as long as quoted and widely traded (in practice, never used so far). ${ }^{13}$ Financial institutions with an account at the central bank, including some securities firms and money market dealers. ${ }^{14}$ High-quality bills of exchange and bonds. ${ }^{15}$ Very broad range, same as for special advances (see Table 4.6). ${ }^{16}$ All institutions with an account at the central bank. ${ }^{17}$ Mortgage bonds. ${ }^{18}$ Marketable bonds and gold. ${ }^{19}$ Including "2.45 lending" and "late-late lending". ${ }^{20}$ Discount houses and giltedged market makers (2.45 lending) and discount houses only (late-late lending). ${ }^{21}$ Clearing banks only. ${ }^{22}$ Treasury bills. 


\section{Annex IV: Discretionary operations: additional information}

Table A.IV.1

Discretionary operations: counterparties

\begin{tabular}{|c|c|c|c|c|c|c|c|c|c|}
\hline & \multicolumn{3}{|r|}{ Operation(s) } & \multicolumn{2}{|c|}{$\begin{array}{c}\text { Eligible } \\
\text { institutions }\end{array}$} & \multicolumn{3}{|c|}{$\begin{array}{l}\text { Special status/ } \\
\text { restrictions }\end{array}$} & \multirow{2}{*}{$\begin{array}{c}\text { Approx. } \\
\text { actual } \\
\text { No. }\end{array}$} \\
\hline & $\begin{array}{l}\text { Main/ } \\
\text { key- } \\
\text { note }\end{array}$ & Other & Name/type & Banks & $\begin{array}{l}\text { Non- } \\
\text { banks }\end{array}$ & $\begin{array}{r}\text { Primary } \\
\text { dealers }\end{array}$ & Other & $\begin{array}{c}\text { Special } \\
\text { credit } \\
\text { line }\end{array}$ & \\
\hline \multirow[t]{2}{*}{$\mathrm{AU}$} & $*$ & & RT, OT & $*$ & $*$ & & $* 1$ & & $20^{2}$ \\
\hline & & $*$ & FXS & $*$ & $*$ & & $* 1$ & & 20 \\
\hline \multirow[t]{2}{*}{ AT } & $*$ & & Weekly tender/RP & $* 3$ & & & & & $30^{3}$ \\
\hline & & $*$ & FXS & $*$ & & & & & 10 \\
\hline \multirow[t]{3}{*}{$\mathrm{BE}$} & * & & Weekly tender/RP, CL & $* 4$ & & & & & 70 \\
\hline & & $*$ & I, RP, OT & $*$ & & * & & $* 5$ & 15 \\
\hline & & $*$ & FXS & $*$ & & & $* 6$ & & 25 \\
\hline \multirow[t]{3}{*}{$\mathrm{CA}$} & $*$ & & TGD & * & $*$ & & $* 7$ & & $12^{7}$ \\
\hline & & $*$ & SPRA/RRP & $*$ & $*$ & $* 8$ & & $* 9$ & $10^{8}$ \\
\hline & & $*$ & SRA/RP & $*$ & & & $* 10$ & & $6^{10}$ \\
\hline \multirow[t]{2}{*}{ FR } & $*$ & & Twice-weekly tender/RP, CL & $* 11$ & & 11 & & & $150^{11}$ \\
\hline & & $*$ & RT, I, OT & $* 12$ & & & & & $<26^{12}$ \\
\hline \multirow[t]{3}{*}{$\mathrm{DE}$} & $*$ & & Weekly tender/RP & $* 13$ & & & & & $400-600$ \\
\hline & & $*$ & Quick tender/RP & $*$ & & & $* 14$ & & .. \\
\hline & & $* 15$ & FXS & $*$ & & & $* 6$ & &.. \\
\hline \multirow[t]{3}{*}{ IT } & $*$ & & $\mathrm{RP}$ & $* 16$ & $* 16$ & 16 & & & 50 \\
\hline & $*$ & & FXS & $*$ & $*$ & & $* 6$ & & 35 \\
\hline & & $* 17$ & Treasury bills/OT & & & $* 17$ & & & 15 \\
\hline \multirow[t]{5}{*}{ JP } & $*$ & $*$ & Bills ${ }^{18} / \mathrm{RP}, \mathrm{RRP}$ & & $* 19$ & & $* 19$ & & 6 \\
\hline & $*$ & $*$ & Treasury bills/RP & $* 20$ & $* 20$ & & $* 20$ & & 59 \\
\hline & & $*$ & $\mathrm{CPs} / \mathrm{RP}$ & $* 21$ & $* 21$ & & $* 21$ & & 47 \\
\hline & & * & Government bonds/RP & $* 22$ & $* 22$ & & $* 22$ & & 53 \\
\hline & & * & Government bonds/OT & $* 23$ & $* 23$ & & $* 23$ & & 61 \\
\hline \multirow[t]{4}{*}{ NL } & $*$ & & Regular tender/CL & $* 24$ & & & & & $12-25$ \\
\hline & & $*$ & Central bank paper/S & $* 25$ & & & & & $8-12$ \\
\hline & & $*$ & I & $*$ & & & $* 26$ & & $1-3$ \\
\hline & & $*$ & FXS & $*$ & & & $* 6$ & & $1-3$ \\
\hline \multirow[t]{2}{*}{ ES } & $*$ & & Regular tender/RP & $* 27$ & & & & & $100-150$ \\
\hline & & $*$ & $\mathrm{RT}$ & $*$ & & & $* 28$ & & 13 \\
\hline SE & $*$ & $*$ & Weekly tender \& other/RP, I & $*$ & $*$ & $*$ & & & $11^{29}$ \\
\hline $\mathrm{CH}$ & $*$ & $*$ & FXS, RT, TGD & $* 30$ & & & & & $15^{30}$ \\
\hline \multirow[t]{4}{*}{ UK } & * & & Eligible bills/OT ${ }^{31}$ & & $* 32$ & & $* 32$ & $* 33$ & 7 \\
\hline & & $*$ & Gilts repo/RP & $* 34$ & $* 34$ & & & 35 & 20 \\
\hline & & $*$ & Treasury bill tender/S & $* 36$ & $* 36$ & & & & 15 \\
\hline & & * & Treasury bill sales/S & $* 37$ & $* 37$ & & $* 37$ & & 22 \\
\hline US & $*$ & $*$ & RT, OT & & $*$ & $* 38$ & & & 50 \\
\hline
\end{tabular}




\section{Footnotes to Table A.IV.1}

${ }^{1}$ In principle, any member of the Reserve Bank Information and Transfer System (RITS). ${ }^{2}$ A roughly equal number of banks and non-banks, out of a total of 136 eligible counterparties (53 banks and 83 non-banks). ${ }^{3}$ In principle, all domestic credit institutions under the Austrian Banking Act which are subject to reserve requirements (de facto the number is limited to 60 since only the head institutions of sectoral banks are admitted). ${ }^{4}$ All credit institutions established in the BLEU with a credit line with the central bank. ${ }^{5}$ Within a quota, special credit/deposit facility at the central rate. ${ }^{6}$ Domestically located institutions active in the foreign exchange swap market. ${ }^{7}$ Direct clearers $(8$ banks, 4 non-banks). ${ }^{8}$ Jobbers, i.e. core group of primary distributors making the market for government securities (5 dealers and 3 banks); until mid-1995, also main counterparties for outright sales of Treasury bills. ${ }^{9}$ Purchase and Resale Agreements (PRAs) for the five investment dealer-jobbers, at Bank rate. ${ }^{10}$ Six major banks. ${ }^{11}$ All banks established in France can participate, but the bids are transmitted via the 26 principal market operators (OPMs). ${ }^{12}$ In practice, with most active banks. ${ }^{13}$ All credit institutions subject to reserve requirements. ${ }^{14}$ Active money market participants. ${ }^{15}$ In addition, any bank may act as counterparty in the sale of liquidity paper used to set a floor to market rates, when necessary. ${ }^{16}$ All banks and primary dealers (specialists) in the screen-based market for Treasury bonds (MTS). ${ }^{17}$ MTS primary dealers. In addition, the central bank carries out occasional bilateral reversed and outright transactions in Treasury bonds to ensure a smooth functioning of the market or limit bond price fluctuations (mostly with primary dealers). The corresponding impact on liquidity is sterilised. ${ }^{18}$ Purchase of bills issued by financial institutions and sales of central bank and financing bills. ${ }^{19}$ Money market ("Tanshi") dealers. ${ }^{20}$ Money market dealers (6), banks (26) and securities firms (27). ${ }^{21}$ Money-market dealers (6), banks (26) and security firms (15). ${ }^{22}$ Banks (26) and securities firms (27). ${ }^{23}$ Banks (25) and securities firms (36). ${ }^{24}$ All credit institutions established in the Netherlands and participating in the quota scheme. ${ }^{25}$ Same counterparties as for regular tenders plus foreign central banks. ${ }^{26}$ Covert intervention, the central bank selects one of the major banks in turn. ${ }^{27}$ All credit institutions subject to reserve requirements. ${ }^{28}$ Group of "market makers" in government bond market selected by the central bank on the basis of their level of activity in both government bond and interbank deposit markets. ${ }^{29}$ Including seven banks (one located abroad) and four non-banks, all members of the settlement system; fine-tuning deposit transactions (I) through which the central bank injects liquidity are carried out only with Swedish banks (7). ${ }^{30}$ In principle, all domestically located banks; in practice, about 15 with the bulk of the operations being done with the three largest. ${ }^{31}$ Including bill/floating rate gilts repos. ${ }^{32}$ Discount houses, institutions subject to several obligations: expected to offer callable deposit facilities to banks and non-banks, making markets in bills, participating actively in the central bank's money market operations and underwriting the weekly Treasury bill tender. 33 "2.45" and "late-late lending". ${ }^{34}$ All domestically located banks, building societies and giltedged market makers (GEMMs). 35 "2.45 lending" for GEMMs. ${ }^{36}$ No restrictions; anyone can bid. ${ }^{37}$ Discount houses (7) and clearing banks (15). ${ }^{38}$ Subject, in particular, to the requirement of participating in the central bank's auctions. 


\section{Annex V: Resisting exchange rate pressures}

It is at times when exchange rate commitments come under severe pressure that monetary policy operating procedures face the toughest test. On these occasions both liquidity management and signalling can be stretched to the full. The ERM turbulence in 1992, for instance, left a profound mark on techniques of policy implementation in Europe. By revealing potential, hitherto largely unsuspected limitations in existing arrangements, the crisis led to temporary as well as permanent changes in the range of instruments, the maturity and frequency of operations and rate-setting mechanisms.

This annex looks at the problems that periods of strong exchange rate pressure can pose for operating procedures and at ways in which they have been tackled. Liquidity management and interest rate setting aspects are considered in turn. As an illustration, much of the analysis draws on events during the exchange market turbulence in the summer-autumn of 1992 in the ERM and in Canada.

\section{Liquidity management}

When exchange rate pressures are resisted through intervention, the task of liquidity management is to allow the central bank to set interest rates without being constrained by the "autonomous" creation of bank reserves through the foreign channel, as net holdings of foreign assets are run down or accumulated. In other words, it is to permit the central bank to decide as freely as possible the pace and extent, if any, of changes in the interest rates under its control or close influence. This essentially means setting reserve balances at the level deemed appropriate for monetary policy purposes, by effectively "sterilising" the excess/shortage of liquidity induced by the foreign channel. ${ }^{104}$

The net creation of liquidity through the foreign channel can be huge, amounting in some cases to large fractions of the outstanding stock of policy instruments. These flows, as the unprecedented ones recorded during the ERM turbulence, can put the central bank's sterilising capability under serious strain (Graph A.V.1). Since the implications of sterilisation are quite different depending on whether intervention injects or withdraws liquidity, it is best to consider each of these two cases separately.

In countries where exchange rates come under upward pressure, central bank purchases of foreign for domestic currency will tend to increase domestic liquidity. ${ }^{105}$ The main risk is that the central bank may not have sufficient ammunition to withdraw it, in which case market rates could fall to zero. Several factors can restrict the operational freedom of the central bank: legal prohibition to pay interest on its deposits or ceilings on the maximum amount of paper that can be sold on its own behalf or on behalf of the government (e.g. Germany), the limited marketability of foreign exchange claims for use in swap operations, the absence of reserve requirements (e.g. Belgium) or of liquidity-absorbing reversed sales against domestic currency claims (e.g. Germany and the Netherlands). While such instruments can be added to the armoury of weapons, it is often difficult to do so at short notice.

104 Of course, the central bank is interested only in the overall creation of bank reserves, not in the individual components. In that sense, it may be misleading to say that individual components are sterilised.

105 When foreign central banks intervene, the effect is similar unless they finance the intervention with official reserve balances held in the markets, in which case there is no direct impact on the balance sheet of the central bank in the country of issue. Part of the intervention at the time of the ERM turbulence was implemented this way. 
Graph A.V.1

\section{Liquidity management during the 1992 ERM turbulence}

Changes, as a percentage of cash and reserves

$\square$ Net foreign influence*

$\square$ Other factors

Germany
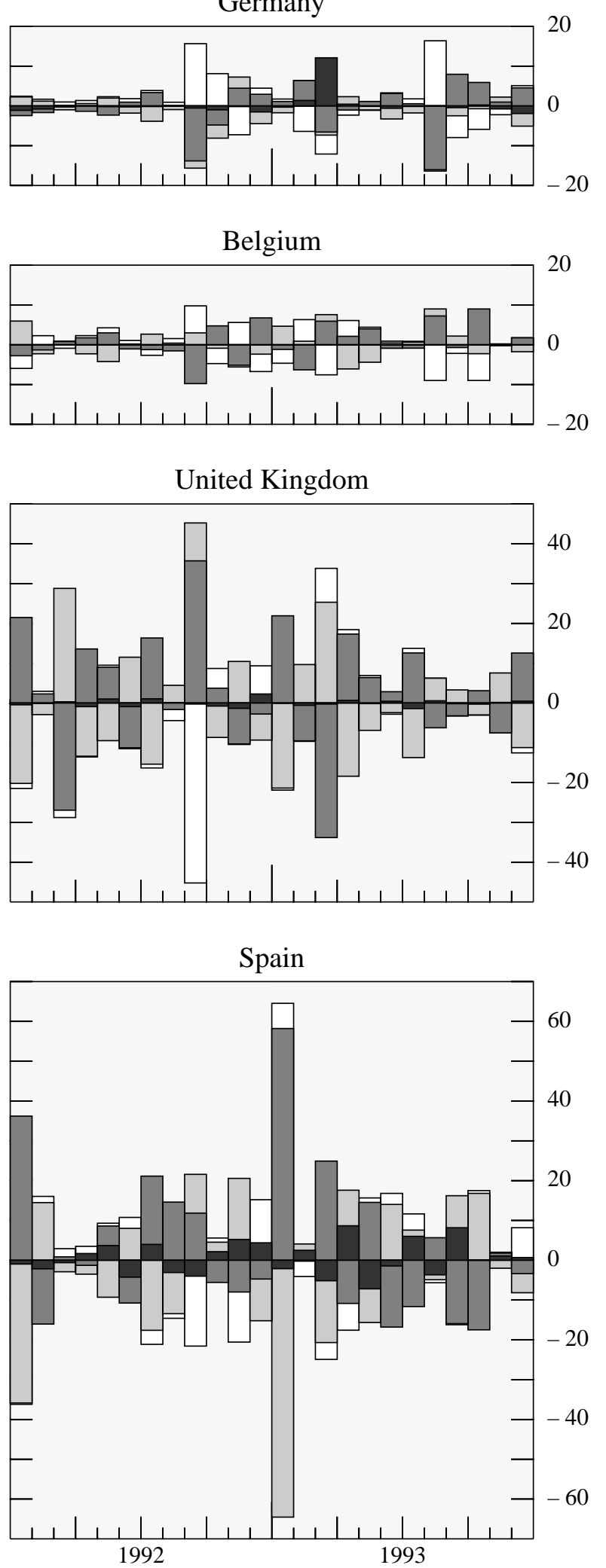

* For Belgium, including foreign exchange swaps used to adjust domestic liquidity.

Bank reserves
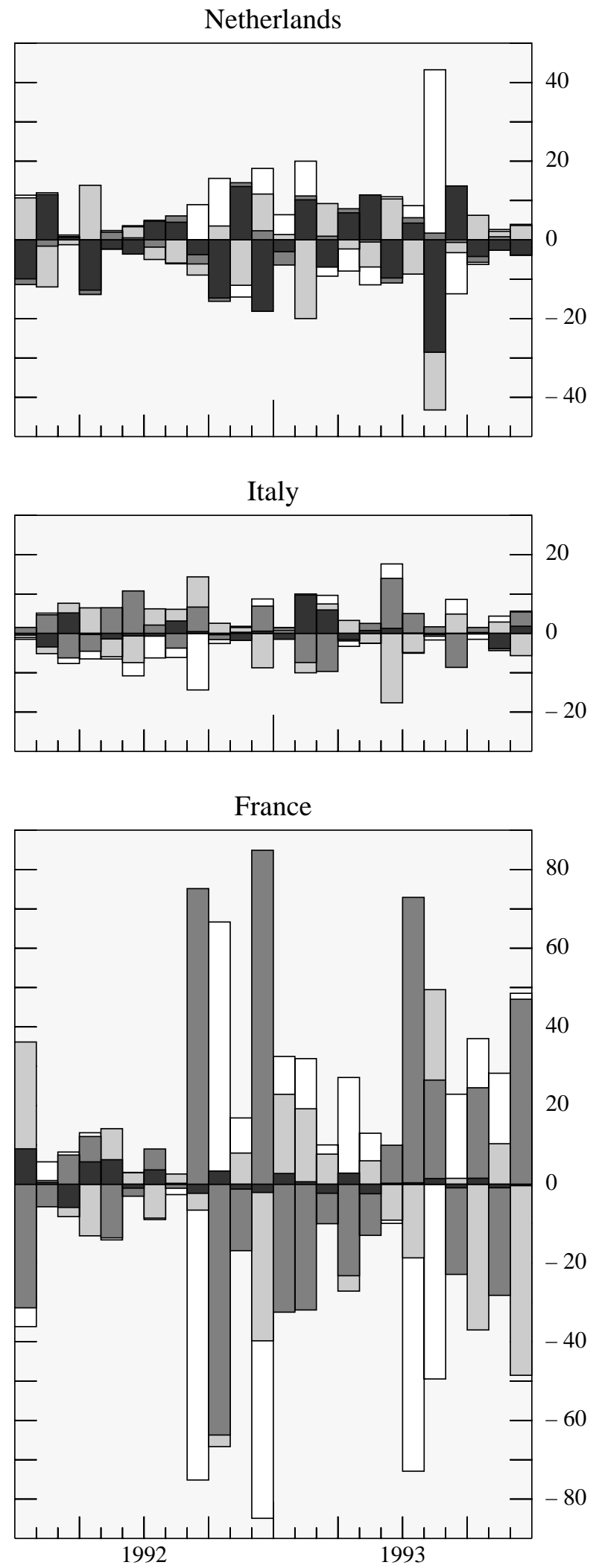
In the event, the countries facing liquidity surpluses in 1992 managed to absorb them through a continuing reliance on existing instruments, the reactivation of unused ones and the introduction of new instruments. In Germany, where the size of the central bank's balance sheet made the challenge more manageable, the authorities allowed outstanding repos to mature, cut the size of new allocations at tenders, activated reversed transactions against foreign currency and began to issue Treasury ("liquidity") paper, in the form of a very short-term (three-day) quasi-standing facility. In Belgium the central bank relied on a large scale on foreign exchange swaps, which had hardly been used until then: in this case, intervention tended to generate its own liquidity-withdrawing ammunition. ${ }^{106}$ In the Netherlands, the flexible reserve requirement mechanism was successfully put to the test. Events also left a mark on the maturity and frequency of operations. In an effort to increase the flexibility of liquidity management, notably the amount of maturing central bank credit at any given time, both the Bundesbank and the Netherlands Bank cut the maturity of their regular keynote operations. In addition, in order to limit the injection of liquidity, the Bundesbank omitted one tender and the National Bank of Belgium halved their frequency. Most of these changes have survived to the present day. None of the central banks in this group, however, has added reverse repos against domestic assets to the range of available instruments.

In countries where exchange rates come under downward pressure, central bank purchases of domestic for foreign currency lead to a withdrawal of liquidity. ${ }^{107}$ The risk is that the authorities may not succeed in injecting sufficient funds to meet the minimum settlement balance needs of banks, effectively losing control of very short-term rates and disrupting the settlement process. At first sight this may appear implausible: the central bank should in principle be able to grant credit at will. A limitation, however, may be the availability of acceptable collateral and sufficiently deep secondary markets. In September 1992, for the first time in a number of continental European countries, including France, Italy and Spain, the amount or distribution of collateral in the system represented a constraint on policy.

The central banks' response was in some respects similar to that of their counterparts facing large inflows. Instruments were newly introduced or reactivated, such as foreign exchange swaps in Italy and repos against gilt-edged paper in the United Kingdom; ${ }^{108}$ these instruments are now routinely employed. Specific steps were taken to overcome the constraints on the availability or distribution of domestic currency collateral, including the reactivation of a long-dormant credit line in Spain, an increase in the fraction of commercial bills accepted for repos in France and a broadening of the range of counterparties in the United Kingdom. In addition, the Bank of Spain brought forward a reduction in reserve requirements planned for the following year. The maturity of market operations was temporarily shortened in Italy, where it was comparatively long, in order to limit the potential overhang of liquidity. In the United Kingdom, the temporary gilt repo facility was initially for a maturity of only one week, so as to give the central bank better control over liquidity conditions. It was subsequently renewed at maturities of up to two months. This was done with a view to reducing any undue pressure on the eligible bill market.

\section{Setting interest rates}

Periods of extreme exchange rate pressure raise equally, if not more, serious challenges for interest rate policy (Graph A.V.2). Some of these are of a technical nature, viz. how to go about raising interest rates and making sure that signals are not misinterpreted. Others are more fundamental, viz., even assuming perfect control of interest rates, how best to react to the tide of adverse market sentiment.

\footnotetext{
106 In addition, the central bank cut the amount provided through the discount facility at below market rates.

107 This withdrawal can be delayed by borrowing the necessary reserves or operating in the forward market, effectively sterilising the impact on domestic liquidity for the maturity of the operations.

108 The gilt repo had not been used since 1988.
} 
Graph A.V.2a

\section{Interest rate setting at times of exchange rate pressure}
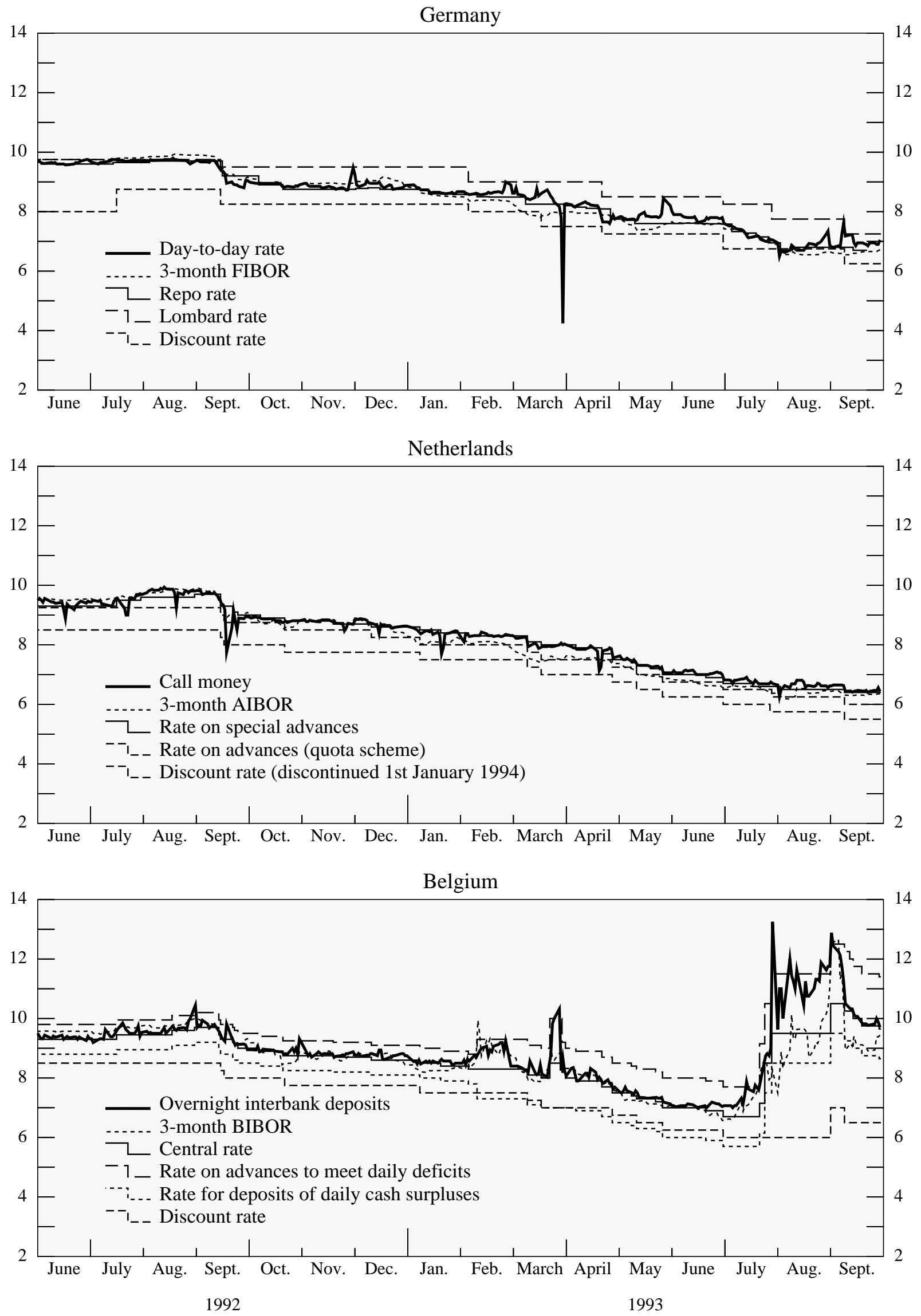
Graph A.V.2b

\section{Interest rate setting at times of exchange rate pressure}

France
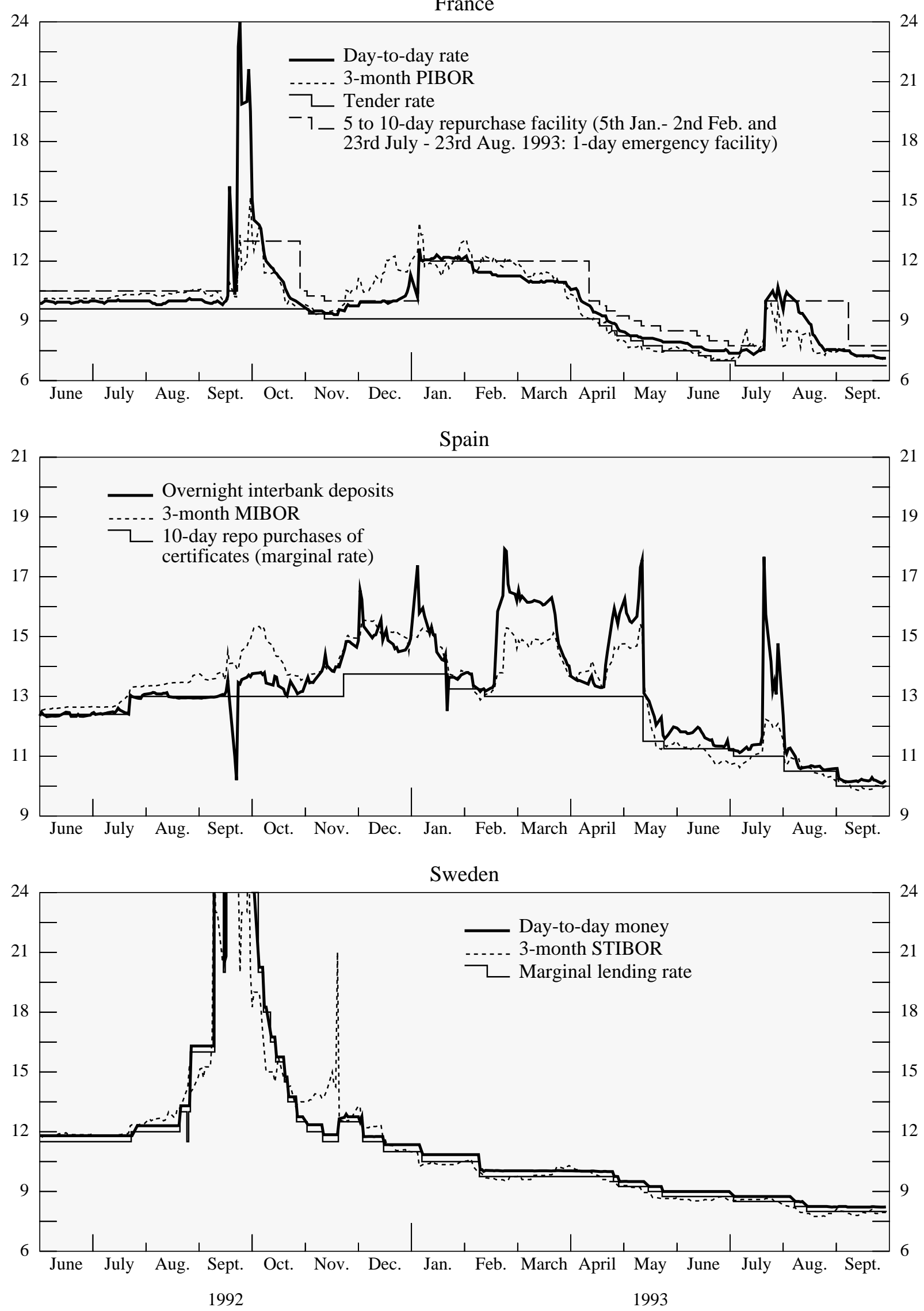
Graph A.V.2c

\section{Interest rate setting at times of exchange rate pressure}
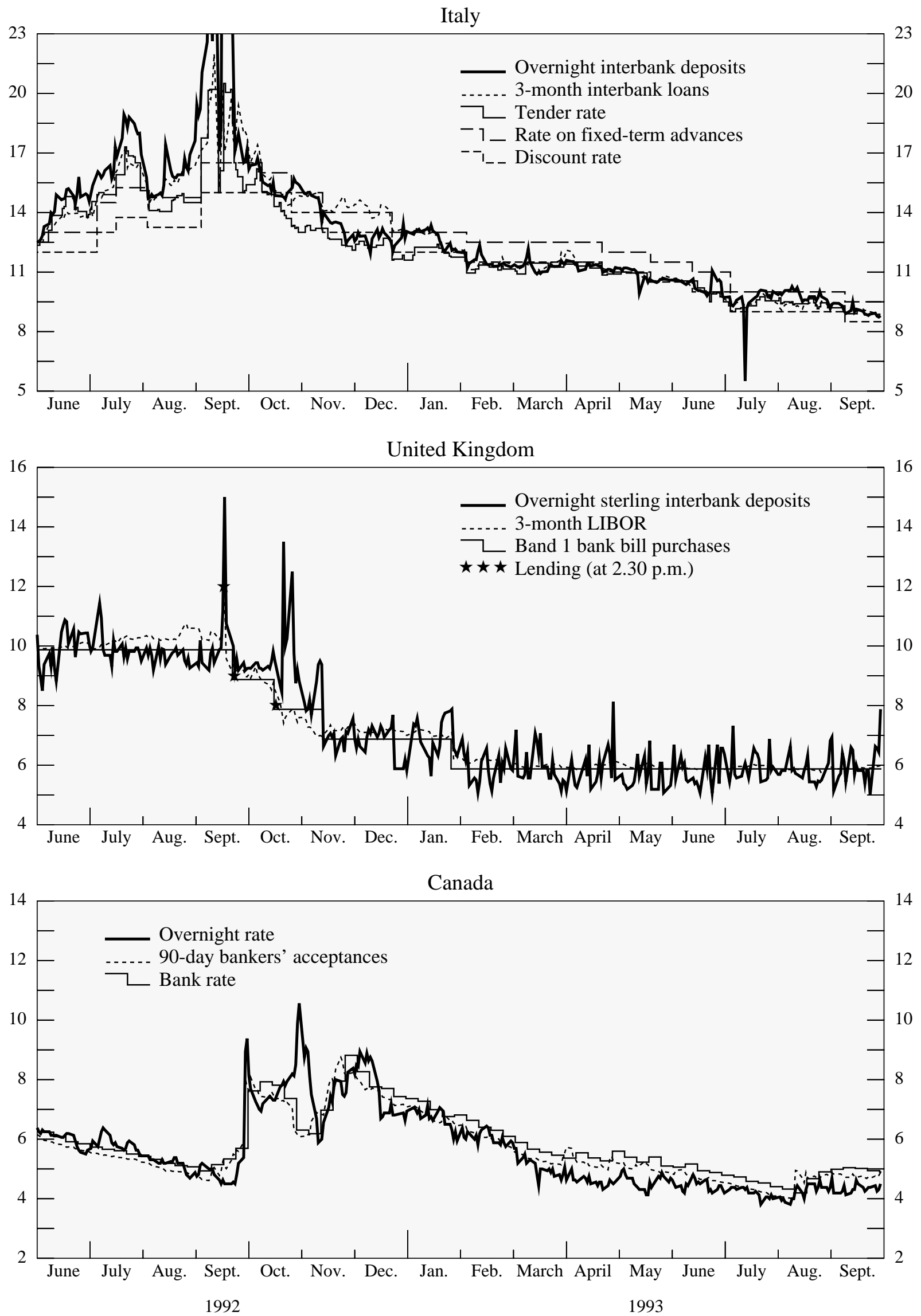
The main problem when faced with unwarranted pressure on the exchange rate is how to demonstrate willingness to resist it while at the same time limiting the dislocation to the stance of monetary policy geared towards domestic objectives. Intervention per se merely buys time: unless exchange rates and/or interest rates are allowed to adjust, it hardly alters the potential gains from testing the exchange rate commitment. Moreover, in conjunction with the sterilisation of foreign flows, intervention supplies the necessary ammunition to sustain the tide of market sentiment: central banks provide participants with the strong currency and with the liquidity in the weak currency for short selling, on credit. ${ }^{109}$

For countries whose currency comes under upward pressure problems are comparatively manageable, at least in the core countries of de facto asymmetric exchange rate arrangements such as the ERM: arguably, the task there is mainly to stabilise the interest rate. ${ }^{110}$ In Germany the shift to fixed rate repos supported by the liquidity paper quasi-standing facility was sufficient. For countries whose exchange rate is attacked the challenge is harder, since the costs of defending the currency are greater. A sustained rise at the very short end of the maturity spectrum risks propagation across the money market yield curve to those rates that play a more significant role in the transmission of policy impulses to the domestic economy, especially to the politically sensitive retail customers.

A typical tactic is to allow the overnight rate to drift up while maintaining or limiting the increase in keynote tender rates or in rates on standing facilities. In Italy in 1992 the central bank rationed credit through the fixed-term advances facility, which normally sets the ceiling to the overnight rate and influences more closely banks' base loan rates. In France the central bank did not alter the tender rates but induced banks to borrow a larger proportion of their funds from the five to ten-day facility at a higher rate; at the same time, the unequal distribution of scarce collateral helped to push the uncollateralised interbank call rate well beyond the rate on the standing facility. When the exchange rate came under more sustained pressure in the summer of 1993, the Bank of France instead suspended the 5 to 10-day facility and replaced it with overnight loans at discretionary interest rates in order to increase the uncertainty of the rollover refinancing costs of sales of domestic currency (settled on a $\mathrm{T}+2$ basis). This tactic has been employed subsequently on occasions of exchange rate pressure. The Bank of Spain abandoned its practice of pre-announcing the weekly tender rate, introduced more frequent and flexible operations and encouraged the decoupling of the overnight rate from the keynote ten-day intervention rate. In addition, with a view to increasing selectively the cost of short selling, it imposed a temporary non-interest-bearing deposit on sales of pesetas by domestic banks to non-residents. The Bank of Sweden allowed the rate on its marginal overnight lending ${ }^{111}$ to rise for a brief period to as much as 500\% in September; in addition, for a while it supplied a small amount of credit to mortgage institutions at below money market rates.

Policies such as these can of course work for limited periods only. Their success partly depends on sound background economic conditions, which over time could defuse the market pressure, or on action to address underlying weaknesses, such as the announcement of fiscal restraint in Sweden. Their successful implementation also requires some form of market segmentation. In countries where neither of these conditions holds, resistance along these lines in not feasible.

Arguably, this was the case in the United Kingdom. In sharp contrast to France, for instance, most lending, even retail mortgages, is at variable rates and bank base rates respond almost instantly to changes in money market rates. Furthermore, at the time of the exchange rate pressure, the

${ }^{109}$ In the international markets, this is done largely through foreign exchange swaps: in effect, it is as if the agent selling the weak currency borrowed it by using the holdings of the strong currency as "collateral".

${ }^{110}$ Problems may arise because of the impact on monetary aggregates, especially if targets are published. The reason is that while the central bank automatically sterilises the impact of exchange market intervention on bank reserves, it cannot as easily sterilise that on the money stock. The increase in resident holdings of short-term DM deposits led to a temporary increase in M3 in Germany. The issue of three to nine-month Treasury bill paper in early 1993 through a tender also open to non-banks was partly designed to absorb these holdings.

111 At the time, the central bank operated with a standing facility at an escalating rate. 
economy was in a weak cyclical position and the household sector overburdened with debt. With one to three-month rates responding closely to changes in the keynote tender rate and no independent way of calibrating movements in the overnight rate, the Bank of England's room for manoeuvre was quite limited. Strong indications of resistance through actual increases in the keynote rate could simply have added further fuel to sales of sterling. Holding the rate steady while at the same time not giving the impression of reluctance to raise it as a last resort was an almost impossible task.

Similar but more subtle signalling problems were faced by the Bank of Canada when its exchange rate came under unwelcome heavy downward pressure in the autumn of 1992 against the background of heightened political uncertainty. Much as in the United Kingdom, and in an economy where variable rate credit is also quite widespread, the task was seen as that of limiting the rise in market rates for fear that this could be taken as a sign that the situation was precipitating. The signals, however, did not appear to work entirely as planned.

On 29th September, when money market rates were rising sharply, failure to provide assistance early in the day through repos (SPRAs, to limit increases in the overnight rate), followed by reverse repo operations later in the day as rates had eased back somewhat (SRAs, to limit declines), appeared to be interpreted not as ratification of the late-day lower rates, but as willingness to allow rates to rise: the lower bound was still higher than on the previous day while no clear upper bound had been signalled. ${ }^{112}$ Coupled with continued volatility in the exchange rate, this appeared to generate expectations of further interest rate increases. The Bank of Canada responded by offering repos (SRPAs) the following day at the prevailing, somewhat higher, overnight rate, and by being aggressive through the cash setting, to signal willingness to see the rate decline. The response to the cash setting, however, was very muted and the overnight rate failed to decline. The noisy nature of the signal was heightened at the time by certain technical factors and by the market turbulence, which made it harder for banks to anticipate cash flows and disrupted traditional demand patterns for reserves. In the event, in order to unlock the situation, the following day the Bank of Canada took the unusual step of announcing in the morning that assistance would be available to dealers, if the need arose, at Bank rate. The clear signal worked, and the situation normalised without any assistance actually being provided.

112 At the time, there was no explicit operating band, and SRAs and SPRAs signalled views about the overnight rate consistent with the operating objective for the three-month Treasury bill rate (effectively, Bank rate). 


\section{Annex VI: Real-time gross settlement}

With the exception of the United States and Switzerland, where they have been in operation for quite some time, most countries covered in this study have either just introduced or are planning to introduce RTGS systems in the near future as the main mechanism for settling interbank transactions. ${ }^{113}$ The move is part of a broader effort by central banks to manage more effectively the liquidity and credit risks in the settlement process, heightened in recent years by the spectacular growth in the volume and value of transactions associated with financial liberalisation and innovation. The shift, however, also has implications for the implementation of monetary policy. This annex considers these issues in more detail and somewhat speculatively.

In a discrete-time net settlement system, funds transfer orders are accumulated and finally settled only at the end of the day on a multilateral net basis. In an RTGS system, by contrast, funds transfers are settled at any time, as soon as the sending bank has sufficient funds available on its account with the central bank. The key implication is the need for intraday settlement balances and, generally, intraday credit, neither of which are required with discrete-time net settlement. The key issue is how this additional constraint on financing and hence on transaction possibilities can affect the implementation of monetary policy.

Following the outline of the paper, it is useful to distinguish two types of possible effect: those connected with the demand for bank reserves and those connected with their supply (central bank credit).

\section{The demand for bank reserves under RTGS}

The main question regarding the demand for bank reserves is how the need for intraday settlement balances may affect the characteristics of the demand for end-of-day holdings. The answer probably is that, in general, it would not imply substantial changes. Banks would clearly continue to attempt to minimise their end-of-day balances and these would remain insensitive to market rates. Where a pre-settlement lending/borrowing round restricted to settlement participants is allowed, the situation would not seem to be fundamentally different from that prevailing in net settlement systems: the information available to participants would be broadly similar and so would transaction possibilities.

On the other hand, the efficiency in the settlement process will very much depend on the detailed features of individual systems. Inevitably, settlement on a gross basis makes greater demands on interbank transactions. Unless sufficient central bank intraday credit is available and other liquidity management facilities (e.g. queuing) work smoothly, frictions in the redistribution of reserves could spill over onto end-of-day working balances, making them more unpredictable. Such frictions may be especially an issue in systems characterised by a comparatively large number of banks. ${ }^{114}$ As a result, for any given degree of predictability in autonomous factors, an RTGS system could call for greater reliance on "calibrating", possibly late-day, central bank operations or on standing facilities.

113 The exception is Canada, where the new large-value interbank settlement system will settle on a net basis at the end of the day. A pre-settlement round is designed to allow banks to target approximately zero balances. The new system will imply changes in policy operating procedures. Averaging will be abolished. Official rates on end-of-day deficits and surpluses will be set at Bank rate and Bank rate minus 50 basis points respectively, thereby defining the limits of the operating band for the overnight rate. The Bank of Canada will then balance the market each day via its regular operations.

114 Where there are few banks, information problems are manageable and quasi-netting parallel arrangements can be developed. However, the oligopolistic nature of the market could lead to other types of problems, such as attempts to "corner" the market. 


\section{The supply of bank reserves under RTGS}

The central bank faces essentially two questions. First, what should be the terms on which it grants intraday credit, if any? Second, what should be the relationship between these terms and those applicable to end-of-day (interday) credit?

The question of terms applying to intraday credit has more to do with risk management and the proper functioning of markets than with monetary policy per se. Except in a few cases, especially where very few banks account for the bulk of all large-value transactions, the prevailing view is that specific liquidity management facilities have to be complemented with substantial intraday central bank credit in order to ensure that transactions can be carried out smoothly. Moreover, such credit is, or is planned to be, granted against collateral but otherwise at zero cost. ${ }^{115}$ The only exception is the United States, where no collateral is normally required, but since 1994 a small fee is charged. As a result, there are few, if any, incentives for the emergence of an intraday money market.

From the viewpoint of central bank operations, these decisions regarding the terms on intraday credit raise two issues. The first concerns the mechanisms through which the credit should be provided. This can be done, as in the United States and as planned in several countries, through an overdraft facility, which would then be backed by sufficient collateral or equivalent legal protection. An alternative is to supply ample credit through intraday repos, the set-up arrangement adopted in the United Kingdom since the system was launched in April 1996.

The second issue concerns the potential impact of these systems on the use of collateral at times when liquidity management operations come under strain, as during severe pressure on exchange rates. As discussed in Annex V, the size of flows nowadays can be such that for countries experiencing outflows limits on the availability and efficient redistribution of collateral may be tested. If the amount "blocked" by the supply of intraday credit in the RTGS system is sizable, the central bank could face considerably greater difficulties in sterilising the withdrawal of liquidity. Vice versa, allocation of collateral for interday operations could reduce the available pool for intraday credit, potentially disrupting the normal functioning of markets. The fact that periods of market turbulence are also ones of high market activity and turnover heightens this risk. It is, however, too early to assess its quantitative significance.

As long as the central bank sets the terms on overnight financing separately from those on intraday credit, monetary conditions are not affected by the terms on which intraday finance is provided. A "quantity" spillover can nevertheless take place if amounts of intraday credit outstanding at the end of the day are automatically converted, albeit on different terms, into longer interday finance. This is formally little different from end-of-day credit granted by the central bank to help settlement in discrete-time net settlement systems, sometimes in the form of a standing facility. The question remains, however, whether in practice it may be harder to ration end-of day credit when deemed desirable. Again, this may be particularly important when exchange rate commitments are tested by the markets. In order to limit the risk of such "spillovers", requirements to repay intraday credit by the end of the day and penal terms on residual end-of-day financing can be introduced. Most countries have done so or are planning to.

\section{But looking further ahead ...}

The possibility for the central bank to set separately the terms on intraday and overnight credit relies on the fact that no sequence of intraday credits can substitute for an overnight contract. This is partly because, at present, no settlement system actually operates round the clock, so that "gaps" in "intraday credit" still exist. Moreover, while the foreign exchange market is already, in effect, a 24-hour market, frictions are such that settlement still generally takes place on a $\mathrm{T}+2$ basis.

\footnotetext{
115 Collateral, of course, has an opportunity cost.
} 
Straining one's eyesight into the future, however, it is possible to conceive of a world in which these constraints will gradually disappear. At that point, the neat separation between intraday and overnight credit would no longer hold. Credit over different short, "intraday" horizons would have a specific value and arbitrage would create a well-defined term structure extending to intraday segments. The central bank's control over interest rates would, presumably, retreat further and shorter rates than the current overnight rate could become the fulcrum of policy. No doubt, we are a very long way from such a world. Yet it is difficult to believe that this is not the direction in which gradually, and perhaps inevitably, we are moving. 


\section{Recent BIS Working Papers}

No.

Title

Author

25

April 1995

26

April 1995

27

May 1995

28

August 1995

29

September 1995

30

November 1995

31

December 1995

32

December 1995

33

January 1996

34

January 1996

35

July 1996

36

August 1996

37

September 1996

38

October 1996

39

January 1997
A survey of non-financial sector balance sheets in industrialised countries: implications for the monetary policy transmission mechanism

The monetary transmission mechanism:

evidence from the G-7 countries

The response of short-term bank lending rates to policy rates: a cross-country perspective

The term structure of Euro-rates: some evidence in support of the expectations hypothesis

The information content of the term structure: evidence for Germany

Money demand stability and currency substitution in six European countries (1980-1992)

Testing the quantity theory using long-run averaged cross-country data

The anatomy of the bond market turbulence of 1994

Derivatives and asset price volatility: a test using variance ratios

Monetary policy and the behaviour of interest rates: are long rates excessively volatile?

Varieties of monetary policy operating procedures:

balancing monetary objectives with market efficiency

Estimation of speculative attack models: Mexico yet again

Does the term structure predict recessions?

The international evidence

International agreements in the area of banking and finance: accomplishments and outstanding issues

Banking system failures in developing and transition countries: diagnosis and prediction
John T. Kneeshaw

Stefan Gerlach and Frank Smets

Claudio E.V. Borio and Wilhelm Fritz

Stefan Gerlach and Frank Smets

Stefan Gerlach

Renato Filosa

Stefan Gerlach

Claudio E.V. Borio

Robert N. McCauley

Benjamin H. Cohen

Stefan Gerlach

Joseph Bisignano

William R. Melick

Henri Bernard and Stefan Gerlach

William R. White

Patrick Honohan 

ISSN 1020-0959 